UNIVERSIDADE DE SÃO PAULO

INSTITUTO DE PSICOLOGIA

FELIPE MARTINS-AFONSO

\title{
Daniel: Um corpo em busca de sentidos
}

SÃO PAULO 


\title{
Daniel: Um corpo em busca de sentidos
}

\author{
(versão original) \\ Instituto de Psicologia da Universidade de São Paulo
}

Orientadora: Professora Livre-Docente Marlene Guirado

Tese apresentada ao Instituto de Psicologia da Universidade de São Paulo como parte dos requisitos para obtenção do título de Doutor em Psicologia.

\author{
Área de Concentração: Psicologia Escolar e do \\ Desenvolvimento Humano (PSA)
}

São Paulo 
Martins-Afonso, Felipe

Daniel: um corpo em busca de sentidos / Felipe Martins-Afonso; orientadora Marlene Guirado. -- São Paulo, 2019.

$199 \mathrm{f}$.

Tese (Doutorado - Programa de Pós-Graduação em Psicologia Escolar e do Desenvolvimento Humano) -- Instituto de Psicologia, Universidade de São Paulo, 2019.

1. Estudo de Caso. 2. Análise Institucional do Discurso. 3. Analítica da Subjetividade. 4. Transtorno do Espectro Autista. I. Guirado, Marlene, orient. II. Título. 
Nome: MARTINS-AFONSO, Felipe

Título: Daniel: um corpo em busca de sentidos

Tese apresentada ao Instituto de Psicologia da Universidade de São Paulo como parte dos requisitos para obtenção do título de Doutor em Psicologia.

Aprovado em:

\section{Banca Examinadora}

Prof. Dr.: Instituição:

Julgamento: Assinatura:

Prof. Dr.: Instituição:

Julgamento: Assinatura:

Prof. Dr.: Instituição:

Julgamento: Assinatura:

Prof. Dr.: Instituição:

Julgamento: Assinatura:

Prof. Dr.: Instituição:

Julgamento: Assinatura:

Prof. Dr.: Instituição:

Julgamento: Assinatura: 
Para quem é esse texto?

Isso! Para o DANIEL... 


\section{Agradecimentos}

Agradeço primeiramente à Universidade de São Paulo e ao nosso Instituto de Psicologia.

Agradeço à Banca Examinadora, pela disposição na leitura e discussão de uma pesquisa que me é tão cara.

Agradeço ao professor Lino de Macedo, que nos ajudou em supervisão nesse caso, bem como por sua participação nas Bancas de Qualificação e de Defesa.

Agradeço aos colegas, amigos e parceiros do Grupo de Orientação. Pela leitura atenta e cuidadosa e pelo carinho que, logo de início, demonstraram por essa história, do Daniel e minha.

Agradeço à Karina e ao Thiago, por me abrirem as portas de sua casa e de suas vidas, pela confiança que depositam em mim, e pela parceria já estabelecida, vida a fora. Agradeço à Sônia, pelo carinho, cuidado e dedicação com esses nossos pequenos queridos.

Agradeço à Silvana, pela atenção e paciência que sempre, incondicionalmente, teve com o Daniel.

Agradeço à Luisa Guirado, minha amiga, por ter me levado até o Daniel, por ter me ensinado sobre ele, por ter me inserido no círculo de afeto e de sentidos que ela e ele haviam previamente construído.

Agradeço à Marlene Guirado... por tudo e mais um pouco. De certa forma, são suas as palavras que animam esse discurso e que construíram essa história. Palavras que 
me acompanham no pensar e no agir em todas as esferas dessa vida. Devo a ela o profissional e o homem que sou hoje. Com a Marlene aprendi fundo o que é cuidar, o que é acompanhar.

Ao Daniel, agradeço sem palavras... 
Depois de te perder, te encontro com certeza, talvez num tempo da delicadeza, onde não diremos nada, nada aconteceu, apenas seguirei como encantado ao lado teu. (Todo sentimento, Chico Buarque) 


\section{Resumo}

MARTINS-AFONSO, F. Daniel: um corpo em busca de sentidos. 2019. 199 f. Tese (Doutorado em Psicologia) - Instituto de Psicologia, Universidade de São Paulo, São Paulo, 2019.

Esta pesquisa se desenha sobre um duplo recorte: o primeiro, é o de ser um estudo de caso (Daniel, 11 anos, diagnóstico médico de Transtorno do Espectro Autista); o segundo, é por ela ser orientada pela estratégia metodológica da Análise Institucional do Discurso (AID). Pela AID, a ideia de "caso" será organizada a partir dos conceitos estratégicos de instituição e de discurso, pois consideraremos o "caso" como um dispositivo que configura um conjunto de práticas discursivas que, num determinado momento e lugar, produzem certos efeitos e modos de subjetivação. Assim, que o que se coloca como o objeto de análise (o "caso") será, então, pensado como todo o contexto das relações institucionais, bem como as diferentes formas de exercício e de configuração dos lugares institucionais ocupados por alguém. Esse alguém, nesta pesquisa, é Daniel, um menino que tem diagnóstico médico de autismo, mas, mais importante, que não fala. E na impossibilidade de falar, o discurso de Daniel é corpo e movimento; suas expressões, seus modos de ser e de agir, sua comunicação são, sempre, pelo, no e com seu corpo. Por isso, Daniel impõe a esse trabalho a condição de ser um estudo analítico dos modos de subjetivação de um menino privado da fala como forma de ação sobre e nas relações que vive. Dessa forma, essa pesquisa se coloca uma pergunta limite: como desenhar o quadro de uma analítica da subjetividade, em meio à materialidade dos acasos e acontecimentos da história do Daniel e do acompanhamento terapêutico que dele faço?

Palavras-Chave: Estudo de Caso; Análise Institucional do Discurso; Analítica da Subjetividade; Transtorno do Espectro Autista. 


\begin{abstract}
MARTINS-AFONSO, F. Daniel: a body looking for menings 2019. $199 \mathrm{f}$. Thesis (doctorade in Psychology) - Institute of Psychology, University of São Paulo, São Paulo, 2019.

This research draws on a double scope: first is to be a case report (Daniel, 11 years old, medical diagnosis of Autistic Spectrum Disorder); second is because it is guided by the methodological strategy of Institutional Analysis of Discourse (IAD). By IAD, the idea of "case" will be organized from strategic concepts of institution and discourse, as we will consider the "case" as a device that configures a set of discursive practices that, at a given moment and place, produce certain subjectivation effects. Thus, the analysis object (the "case") configured by this methodological-conceptual scope will then be thought as the whole institutional relations context, as well as the different forms of exercise and configuration of institutional places occupied by someone. This someone in this research is Daniel, a boy who has a medical diagnosis of autism but, most importantly, who does not speak. And in the impossibility of speaking, Daniel's speech is body and movement; their expressions, their ways of being and acting, their communication are always by, in and with their body. For this reason, Daniel imposes on this work the condition that it is an analytical study of the subjectivation modes of a boy deprived of speech as a type action on and in the relationships he is involved with. Thus, this research poses a limit question: how to draw the framework of a subjectivity analytics, amidst the materiality of the events of Daniel's history?
\end{abstract}

Keywords: Case Study; Institutional Analysis of Discourse; Subjectivity Analytics; Autism Spectrum Disorder. 


\section{Sumário}

Abertura

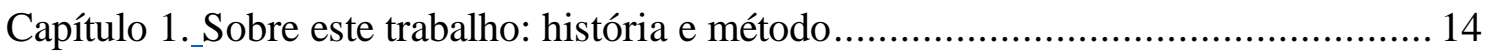

Capítulo 2._Sobre Daniel: uma descrição exemplar ............................................. 40

Capítulo 3._Uma Historiografia Diagnóstica .......................................................... 51

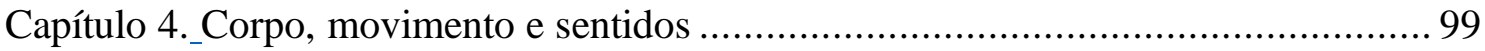

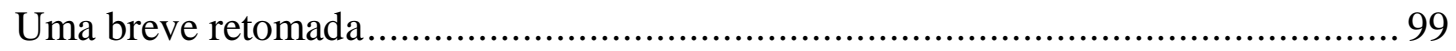

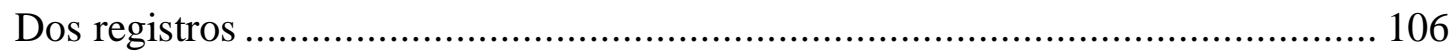

Das impressões e expressões de um corpo à produção de sentidos: a singularidade

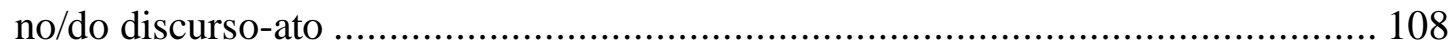

Cenas e discursos: os caminhos dos afetos, das memórias, da singularidade .......... 137

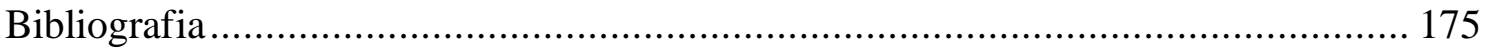

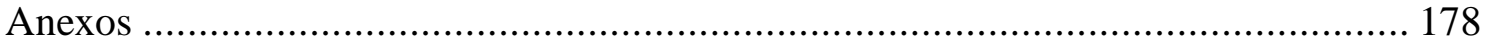

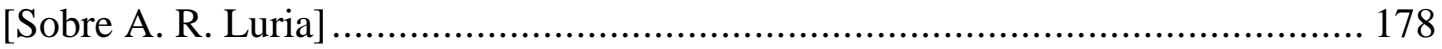




\section{Abertura}

Esta pesquisa se desenha sobre um duplo recorte: o primeiro, é o de ser um estudo de caso (Daniel, $11 \operatorname{anos}^{1}$ ); o segundo, é por ela ser orientada pela estratégia metodológica da análise institucional do discurso (AID) (Guirado M. , 2010; 2000; 1995/2006; 1987/2004; 2015; Guirado \& Lerner, 2007). Conjuntamente, eles definem o âmbito de produção de saber dessa tese, ou seja, o fato de que suas afirmações, análises e argumentações são relativas (a.) ao regime discursivo do método da AID, organizado por um conjunto de conceitos-chave, bem como $(b$. $)$ às condições concretas impostas pelo contexto do acompanhamento que faço de Daniel. Como diz Guirado (Guirado M. , 2010, p. 47), "é aquela história de os fins estarem no início", de que "ouvimos com as palavras que temos para ouvir"... E no caso da pesquisa acadêmica, analisamos a partir do ângulo conferido pelos conceitos que instrumentam nosso pensar ${ }^{2}$. Segundo essa perspectiva, "faz sentido" definir o mais claramente que nos for possível esses recortes: uma vez que eles serão a condição de possibilidade dessa produção acadêmica, não os declarar seria criar a falsa imagem de que o discurso deste trabalho independe dos contextos concretos de seu exercício. Seria criar a falsa imagem de que ele pretende ser uma verdade sem

\footnotetext{
${ }^{1}$ Data de Nascimento: Outubro de 2007.

${ }^{2}$ Essa é a perspectiva epistemológica da Análise Institucional do Discurso de Marlene Guirado. Há nela uma declarada inspiração nas ideias de Foucault (1971/1996; 1979; 2006), o que não imiscui o inegável ineditismo da produção Guiradiana ao trabalhar a questão dos "regimes discursivos" na fronteira conceitual das relações institucionais e dos jogos de reconhecimento e desconhecimento (Guirado, 2010). Ver inclusive o trabalho de Silva (Silva, 2019).
} 
tempo e lugar ${ }^{3}$. É esse o compromisso que estabelecemos para essa Abertura. Iniciemos pelo recorte conceitual do método.

A AID é uma estratégia de pensamento, um método de pesquisa e trabalho em Psicologia produzido por Marlene Guirado, professora Livre-docente e pesquisadora deste IPUSP. Na obra A análise institucional do discurso como analítica da subjetividade (Guirado M. , 2010), a autora apresenta, em sua forma mais completa até o momento, as justificativas e desenvolvimentos conceituais que permitem a sustentação epistemológica desse método na fronteira entre a sociologia das instituições concretas de GuilhonAlbuquerque, a análise pragmática do discurso de D. Maingueneau, as ideias de M. Foucault e a psicanálise de Freud. Resgataremos duas passagens argumentativas desse texto, a partir das quais poderemos caracterizar os efeitos desse recorte na configuração de uma pesquisa. São elas: $a$. a positividade do conceito de instituição e $b$. o conceito de discurso como ato. Vamos lá...

Guirado define instituição como: um conjunto de relações sociais que se repetem e nessa repetição se legitimam; isso pelo efeito de reconhecimento dessas relações como naturais (e legítimas) por parte daqueles que as fazem e pelo desconhecimento de sua relatividade a um tempo e um contexto específicos. Um desdobramento desse conceito é

\footnotetext{
${ }^{3}$ Para discussões desse porte sobre os modos de produção de conhecimento, ver (Guirado M. , A análise institucional do discurso como analítica da subjetividade, 2010); (Foucault M. , A ordem do discurso, 1971/1996); (Foucault M., Verdade e Poder 1979); (Foucault M. , Ditos e Escritos IV: Estratégia, PoderSaber, 2006).
} 
a ideia de que uma determinada prática institucional configura para si um objeto, imaterial, em nome e em razão do qual ela se faz e sobre o qual reivindica monopólio de legitimidade em “disputa” com outras instituições (Guirado M. , 2010, pp. 45-46).

Embora originalmente o conceito seja de autoria de Guilhon-Albuquerque, ao longo de sua obra, Guirado lhe acrescentou a ideia dos efeitos de reconhecimento e desconhecimento por parte dos atores institucionais, positivando assim a possibilidade de pensar singularidade e relações institucionais de modo imbricado. Isso conduz a outra importante discriminação produzida por esse modo de pensar: histórica e rotineiramente, instituição se define como algo que está além dos indivíduos e das relações que concretamente estabelecem; indivíduo e instituição tendem a ser pensados como parteextra-parte e, sobretudo por autores como Lapassade, a relação entre os dois é caracterizada como uma relação de dominação, coerção. Na definição da AID, no entanto, a instituição se constrói, se faz, se repete, se legitima a cada relação que se estabelece entre os atores institucionais.

Guirado avança, ainda, na propositura de que a própria Psicologia pode ser pensada "como uma instituição do conhecimento e da prática profissional" (Guirado M., 2010, p.48); portanto, onde quer que se exerça, ela se fará pelo conjunto de repetições de relações, cujos atores reconhecem determinados fazeres como legítimos e naturais e desconhecem sua relatividade histórica e geográfica.

Nessa linha argumentativa, a partir desse conceito e levando em conta a diversidade das "psicologias", a autora configura à sua proposta um objeto institucional: as relações tal como imaginadas, reconhecidas e desconhecidas, no e pelo discurso, por aqueles que as fazem (Guirado M., p.48). De certa forma, o destaque dado às relações em sua definição é o que permite um trânsito entre singularidade e instituição em determinada 
configuração de contexto. Uma vez que as relações a que se refere Guirado vão "desde aquelas do berço" às estabelecidas vida à fora, e nelas estão previstas, conjuntamente, a mudança e a repetição dessas e nessas relações. Ou seja: a cada relação que estabelecemos em nossa vida, a cada diferente lugar institucional que nos vimos exercendo (filho, marido, psicólogo, etc.) reeditamos as expectativas e ações de relações similares vividas anteriormente, ao mesmo tempo em que alteramos nossas ações e expectativas à medida que a situação presente exigir. Em suas palavras (Guirado M., 2010, p. 49):

[...] a história de vínculos de alguém se reedita, historicamente, na singularidade de sua organização e numa variação ou movimento de mudança inevitavelmente exigido, uma vez que as reedições se fazem, sempre, na medida em que se ocupam lugares em outras instituições. Movimento, repetição, regularidade e singularidade: termos díspares, que de forma paradoxal, articulam-se para falarmos de um sujeito psíquico porque institucional (Guirado M. , 1987/2004) ou, de um matriciamento institucional do sujeito psíquico (Guirado M. , 1995/2006), ou ainda, da metáfora do sujeito-dobradiça (Guirado M. , 1995/2006).

Outro conceito básico da AID que instrumenta a proposta da autora é o de “discurso". Assim como a noção de instituição, esse termo circula em diferentes áreas do conhecimento e com diferentes definições em cada uma delas. Segundo Guirado, na AID, discurso é pensado como formação discursiva, aos moldes das ideias de M. Foucault: um conjunto de dispositivos que define as regras, as posições e os lugares de enunciação para certa comunidade discursiva em determinado lugar geográfico e tempo histórico (Guirado, 2000; 2010). A diferença principal estabelecida nessa definição é de não 
considerar discurso como um conjunto de símbolos organizadores ou representantes de uma realidade, afastando-se assim de uma concepção clássica que dicotomiza significado e significante. Discurso é, segundo a concepção da AID, ato, instituição, acaso e acontecimento (Guirado M., 2010, p. 46). É ato enunciativo. É enunciação-ato. É um modo de pensar as situações de enunciação, com ou sem fala, que diz mais da disposição dos parceiros em cena em determinada relação institucional do que do conteúdo de seus enunciados.

O que importa, porém, é considerar, com Foucault, que os discursos são dispositivos-ato, (por)que supõem, para seu exercício, uma posição, um lugar, que é um lugar na enunciação; isto é, um lugar prenhe de palavras para ouvir e para falar; com os efeitos que isto pode ter sobre a ação de um e outro em relação, num determinado contex to. (Guirado M., 2010, p. 46)

Se o leitor ainda tem em mente a definição de instituição, se lembrará que nela diz-se das relações tal como imaginadas, reconhecidas e desconhecidas, pelo e no discurso... Este é um importante ponto de inflexão das ideias da autora: as ações dos atores institucionais podem ser consideradas atos discursivos, que definem os lugares de enunciação, atravessados pelas expectativas sobre os modos de exercício de determinado lugar institucional. Assim, discurso e instituição se imbricam como organizadores de uma perspectiva analítica, que visa a produzir o desenho imaginário do jogo entre singularidade e dispositivo institucional em determinada relação social. A AID não se configura assim como uma teoria sobre um objeto, mas um método de análise, uma estratégia de pensamento. 
Depois da densidade dessas palavras, se faz necessário um exemplo. Segue um trecho retirado do texto de Guirado:

Imaginemos uma situação de sala de aula em que um aluno discorda do modo como o professor conduz seu curso, e o faz em voz alta, enquanto seus colegas em atento silêncio indicam, senão na totalidade pelo menos em parte significativa deles, concordar com sua fala. $\mathrm{O}$ aluno que discorda, muito provavelmente, reedita, naquela situação, o lugar que se viu e se vê ocupando nas relações que estabelece desde sempre em sua vida e, como tal, na mais absoluta singularidade de ser, que construiu historicamente. No entanto, o fez num movimento que se regra pelas particularidades do lugar de aluno, falando a um professor. A cena assim constituída repõe as tensões de uma relação de poder, repõe o jogo de expectativas e dirige a um incerto ponto de desfecho, a depender sempre dos mesmos fatores: movimento, repetição, regularidades e singularidade. Tudo, historicamente construído, tendendo ao reconhecimento de legitimidade de uma certa forma de se fazer o ensino e a aprendizagem. (Guirado M. , 2010, p. 49)

Pensamos que este exemplo permite ao leitor antever, em linhas gerais, os efeitos que o recorte da análise institucional do discurso confere na determinação dos "focos" de nossa atenção: movimento, repetição, regularidade e singularidade, como caracterizou Guirado. 
O outro recorte básico desta pesquisa é o fato de ela ser um estudo de caso, e mais que isso, um estudo de caso em e pela análise institucional do discurso. O que implica que a própria ideia de "caso" será organizada a partir dos conceitos estratégicos de instituição e de discurso. Decorre disso que ao falarmos de "caso" não estaremos nos referindo ao indivíduo em si e por si ou, ainda, a uma patologia (um caso de autismo, um caso de afasia, um caso de dislexia, por exemplo), ao invés disso, deveremos considerar o "caso" como um dispositivo que configura um conjunto de práticas discursivas que, num determinado momento e lugar, produzem certos efeitos e modos de subjetivação. Assim, o objeto de análise (o "caso") configurado pelo recorte metodológico-conceitual da AID é, então, todo o contexto das relações institucionais, bem como as diferentes formas de exercício e de configuração dos lugares institucionais ocupados por alguém.

Esse alguém, nesta pesquisa, é o Daniel, um menino nascido no ano de 2007, com onze anos de idade no momento em que escrevo. Eu o atendo em "regime" de acompanhamento terapêutico, quatro vezes por semana, e isso já dura quatro anos. De tudo que se poderia dizer nessa abertura para o descrever minimamente, nada é mais importante do que o fato de ele não falar. Quando o conhecemos, com 6 anos, sequer gestos comunicacionais utilizava para dizer o que quer que fosse. Nada, além de um choro, dolorido por vezes, dizia de si. Consideramos esse um dos fatores mais relevantes pois ele impõe uma forma muito singular no modo como Daniel ocupa um lugar nas relações que estabelece: é que na impossibilidade de falar, o discurso de Daniel é corpo e movimento; suas expressões, seus modos de ser e de agir, sua comunicação são, sempre, pelo, no e com seu corpo. Daniel impõe a essa pesquisa a condição de ela ser um estudo analítico dos modos de subjetivação de um menino privado da fala como forma de ação sobre e nas relações que ele se vê envolvido. 
Aqueles, porém, que, como eu, diariamente se relacionam com ele, com muita naturalidade atribuem sentidos a seus gestos, ações e expressões. As crianças de sua escola são das mais sensíveis a seu estado, e sempre comentam sobre o que acham que ele gostou ou sobre sua intenção ao fazer determinado movimento. Muito respeitosamente, elas traduzem para as nossas palavras as intenções que pensam ser as dele. Assim, por exemplo, uma menina ao observar o Daniel correr para fora da sala o segue e o intercepta na escada que leva ao pátio e, quando me aproximo, ouço-a falar: “Daniel, o lanche é daqui há pouco, já, já vamos descer”. Alguns adultos adotam uma postura similar, uma de suas professoras, por exemplo, montou com ele um álbum com as fotos de um passeio que fizemos com seus colegas de turma, ela lhe mostrou todas as fotos de que dispunha, recontando-lhe os acontecimentos daquele dia; uma delas o flagrava subindo numa mureta, a professora, então, comentou em referência a isso que "subir na mureta" fora uma peraltice dele, igual a outra que havia feito instantes antes de sentar-se para ver aquelas fotos. Ela por fim exclamou, "Viu?! Como algumas coisas se repetem na nossa vida?". Há, intencional ou intuitivamente, por parte dessas pessoas uma disposição de igualdade e simetria na relação que estabelecem com o Daniel. ${ }^{4}$

Essa será, em princípio e no fim, também a nossa disposição básica: considerar que Daniel forma vínculos, a seu modo e sem palavras. Mais (como discutiremos depois): que os registra em sua memória e que os carreia, como expectativas, para as novas relações que estabelece. E, sim, consideramos também que Daniel, mesmo privado de muitas habilidades sociais, cognitivas e motoras, estabelece singulares formas de contato,

\footnotetext{
${ }^{4}$ Por outro lado, outros profissionais que o atendem em terapias diversas, curiosamente, nem sempre lidam com ele com essa mesma disposição. Trataremos disso ao longo do texto.
} 
de relação e de comunicação com os outros e com o ambiente que o cerca. No discurso formal do método, Daniel é um ícone na sua singularidade, que se destaca sem nunca se confundir com a materialidade de todo o contexto... ${ }^{5}$

Há uma segunda condição imposta ${ }^{6}$ a essa pesquisa: se o discurso de Daniel tem como instrumento de ação seu corpo e movimento, é necessário que seu interlocutor proceda a uma observação atenta que possa registrar e acompanhar as direções, mudanças e repetições dessas ações, movimentos, expressões, gestos e comportamentos, enfim, de tudo aquilo que compõe o discurso de Daniel.

Com isso corremos o risco de, por um lado, passar a impressão de que creditamos ao procedimento de observação a possibilidade de nos apresentar um dado empírico, um fato concreto e material, impessoal e imediato. Por outro lado, se fugimos dessa conotação, corremos o risco de ter nosso trabalho considerado "subjetivo demais", ensaístico, que apresente um ponto de vista e um conjunto de ideias parciais em detrimento dos dados e fatos empíricos. No entanto e felizmente, a dicotomia empírico/subjetivo não se aplica em nosso caso, pois a AID nos instrumenta a considerar, no mesmo tempo da observação, o modo como o observador ocupa seu lugar. Essa ideia deriva da perspectiva de que, nas análises que empreendemos em AID, partimos da consideração do "contexto para a produção do sentido" (Guirado M. 2010, p.184).

\footnotetext{
${ }^{5} \mathrm{Na}$ sua melhor versão concreta: o Sujeito-dobradiça... Tal como se verá no Capítulo 1. Sobre este trabalho. ${ }^{6}$ A primeira condição, como dissemos: "Daniel impõe a essa pesquisa a condição de ela ser um estudo analítico dos modos de subjetivação de um menino privado da fala como forma de ação sobre e nas relações que ele se vê envolvido.

${ }^{7}$ Isso será tratado com maior profundidade no capítulo seguinte.
} 
Sem muito ou nada pensar, talvez a professora e a menina tenham procedido por esse mesmo caminho da observação atenta. É provável que tenham observado no Daniel sinais e tenham lhes atribuído algum sentido ao qual responderam; é, pelo menos, o que sugerem suas falas, nas cenas que descrevemos acima. Sinais como a direção de seu olhar, a expressão facial, sua postura, a tensão e a intenção do movimento, o contexto... o discurso-ato-Daniel.

É, portanto, em função desses dois recortes básicos - o metodológico-conceitual e o das condições impostas pelo "caso" de Daniel - que essa pesquisa se coloca uma pergunta limite: como desenhar o quadro de uma analítica da subjetividade, em meio à materialidade dos acasos e acontecimentos da história do Daniel e do acompanhamento terapêutico que dele faço? Receamos sermos levados (pelos acasos? Acontecimentos?) a andar mais por zonas de obscuridade do que por linhas claras, pois corremos o risco de colocar muito de nós mesmos, de emprestarmos, ou pior, imputarmos palavras e sentidos a um discurso que é, em princípio, do Daniel, produzido e construído por e com ele.

Afastamo-nos assim dos modos de produção de conhecimento exigidos para um discurso acadêmico como o de uma Tese de Doutorado?

Essa pergunta sobre os limites e possibilidades da pesquisa acadêmica em contextos obscuros talvez não seja a melhor forma de abrir uma Tese de Doutorado, pois a imputa uma tarefa de enorme peso e envergadura, que receamos não sermos capazes de realizar. Com sorte, neste ponto da escritura, fomos socorridos por nossa orientadora, que nos (re)apresentou as palavras de um Freud-escritor como esteio e inspiração para esse caminho: 
É óbvio que um caso [Homem dos Lobos] como o que está descrito nestas páginas pode transformar-se num pretexto para $p \hat{o} r$ em discussão todas as descobertas e problemas da psicanálise. Isso, contudo, seria um trabalho infindável. Deve-se reconhecer que nem tudo se pode aprender a partir de um único caso e que nem tudo pode ser resolvido através dele; devemo-nos contentar em explorar tudo aquilo que porventura se mostre de forma mais clara. Existem, em qualquer caso, limites estreitos para aquilo que a psicanálise foi chamada a explicar. Pois, ao passo que é da sua alçada explicar os sintomas revelando a sua origem, não o é explicar, mas simplesmente descrever, os mecanismos psíquicos e os processos instintuais aos quais a pessoa é desse modo conduzida (Freud, [1914]1918/1976, p. 132, grifos nossos).

A Análise Institucional do Discurso será o substrato conceitual-metodológico de que nosso estudo, como um todo, derivará, e não a psicanálise de Freud. No entanto, têlo como ponto de apoio, nessas encruzilhadas do saber, é de poder incontestável. Mais que isso, enche-nos de responsabilidade. E o texto acima mostra como ele nos socorre e serve de exemplo... Em trabalhos como esse, não se pode saber tudo, nem tudo decidir. Devemos aproveitá-lo naquilo que mostra mais nitidamente. Explicar o que for possível e, quando não, se contentar em descrever.

Com essas palavras, nosso salvo conduto e uma prescrição ética para o trabalho e a pesquisa: descrever. 


\section{Capítulo 1.}

\section{Sobre este trabalho: história e método}

Seria natural se utilizássemos esse espaço para apresentar o Daniel, a partir de uma descrição geral de situações, de seus modos de ação e reação em cenas exemplares. No entanto, essa apresentação será adiada para o capítulo seguinte, pois ainda são necessários alguns ajustes conceituais para podermos desenhar a "tese" que anima essa pesquisa.

Neste, que consideramos como um capítulo de Introdução, trataremos, além da organização geral do trabalho, de alguns ajustes e avanços conceituais necessários para a sustentação das diversas formas de seu exercício.

O final do parágrafo anterior já nos exige a primeira explicação: de quais formas diversas de exercício do trabalho falamos? Pois bem. Essa pesquisa, uma Tese de Doutorado na forma de um estudo de caso, é um trabalho acadêmico sobre um menino e o acompanhamento terapêutico que dele fazemos. Mas há, além disso, o próprio acompanhamento terapêutico, que é um trabalho caracteristicamente clínico. Assim, temos, em princípio, dois registros discursivos - o terapêutico e o acadêmico - que se alinham e se alimentam na escritura deste texto ${ }^{8}$, por dois motivos principais.

\footnotetext{
${ }^{8}$ Esse movimento será descrito no item tempo de mudança, abaixo, ainda neste capítulo.
} 
O primeiro motivo é de ordem concreta: foi no acompanhamento terapêutico de Daniel, das questões e angústias que ele gestou, que se configurou um campo para a pesquisa acadêmica. Assim, tanto um trabalho quanto o outro tem um mesmo tema e norte: o Daniel. Esse fato tem algumas implicações: $a$. a pesquisa acadêmica guardará as marcas do trabalho concreto, uma vez que este é sua base de referência e seu guia; $b$. embora assim seja, o trabalho de pesquisa e de escritura no formato de uma Tese, sobretudo, se desenvolve em outro registro discursivo e, por esse motivo, permite avançar em considerações analíticas e conceituais que ultrapassam os limites estritos do acompanhamento terapêutico; $c$. por fim, essas considerações analíticas e conceituais, características do trabalho acadêmico, têm dois efeitos, o primeiro é da ordem de abrir caminhos e possibilidades diretamente para o próprio atendimento de Daniel, o que se fazia no ato mesmo de seu acompanhamento, sempre pensado e discutido em supervisões e orientações à pesquisa; o segundo é o de enlaçar, no plano acadêmico, discussões sobre método de pesquisa e trabalho em psicologia, análise de situações concretas e intervenções terapêuticas, fazendo avançar a própria estratégia de pensamento 9 .

O segundo motivo é da ordem da perspectiva analítica com a qual se trabalha. Do acompanhamento terapêutico à pesquisa acadêmica, nossa estratégia de pensamento é a da Análise Institucional do Discurso (AID). E embora já tenhamos falado um pouco sobre isso na Abertura, precisaremos retomar algumas ideias para poder avançar nas compreensões que se fazem necessárias para esse momento. A principal característica da AID é o fato de não se configurar, nem como uma teoria (sobre um objeto do

\footnotetext{
${ }^{9}$ Trataremos desse ponto também no item tempo de mudança, ainda neste capítulo.
} 
conhecimento), nem como uma metodologia (definida por procedimentos e etapas de trabalho), mas como um modo de pensar e fazer psicologia onde quer que ela se dê (nessa pesquisa e na intervenção concreta com o Daniel, por exemplo). Como uma estratégia de pensamento, portanto, as implicações da AID para nosso trabalho são de ordem basal, de sustentação, implicando um conjunto de reorientações de perspectivas sobre: $a$. o modo de produção de conhecimento na pesquisa acadêmica, que se faz, por meio de análises de discurso, numa referência constante às suas condições de produção (recortes de método e de "objeto" de estudo); $b$. o exercício de um acompanhamento terapêutico como uma analítica da subjetividade; $c$. o lugar das teorias e conhecimentos na pesquisa e no trabalho terapêutico ${ }^{10}$.

Por esses dois motivos podemos dizer, em linhas gerais, que este trabalho é uma análise institucional do discurso do Daniel e do acompanhamento terapêutico que dele fazemos. Em outras palavras, também poderíamos dizer dele como o exercício de uma analítica da subjetividade (Guirado M. , 2010).

$\mathrm{Na}$ sequência explicaremos e justificaremos, em quatro itens, o que queremos dizer com uma "analítica da subjetividade". Para isso partiremos das questões do acompanhamento e do contato direto com Daniel que instigaram as primeiras perguntas de pesquisa, bem como o tratamento que pela AID pudemos dar a elas (o título deste item é: $O$ tempo das primeiras questões). Em seguida, no item $O$ tempo de mudança, acrescentaremos algumas considerações de método e de análises de contexto a fim de dar corpo, neste trabalho, às questões iniciais. No terceiro item, $O$ tempo da escritura atual,

\footnotetext{
${ }^{10}$ Essas questões igualmente serão abordadas no item tempo de mudança.
} 
apresentaremos e justificaremos conceitual e analiticamente o que é e como se constitui essa pesquisa. Por fim, no item A organização do texto, trataremos do modo como dispomos seus capítulos principais. Com isso cumpriremos o prometido para este capítulo.

O tempo das primeiras questões

A primeira vez que, como psicólogo, atendi Daniel, fui tomado por um sentimento de impotência. Havia uma exuberância e ao mesmo tempo demasia em suas atitudes, em sua força, seu movimento, seus sintomas, emoções e afetos para as quais não havia registro em minha experiência, muito menos recursos conceituais, teóricos ou procedimentais para a elas responder. Era tudo por demais. Esse sentimento ganhou algumas formas e expressões nos inícios desse acompanhamento, a mais acabada, sem dúvida, foi a de um Projeto de Pesquisa de Doutorado, que foi a primeira formalização acadêmica deste trabalho.

Em meio a esse turbilhão se concretizou seu primeiro esboço. A pesquisa versaria sobre a questão diagnóstica em psicologia, ou melhor, seria um mapeamento diagnóstico dos modos de Daniel agir no mundo, dos modos de se relacionar com as pessoas, com os objetos, dos modos de brincar, etc. Um diagnóstico assim posto e configurado para, em parte, responder e aplacar a inquietação provocada pelo desconhecimento sobre o Daniel. Mas também, porque seria ocasião de pôr à prova (da comunidade científica?) o modo de trabalho da Análise Institucional do Discurso, em condições e configurações atípicas, de diversos elementos. A nosso ver, no entanto, a principal justificativa era a produção de 
um discurso sobre alguém que, por diversos motivos, tem a palavra roubada, ou seja, tem seu lugar de enunciação capturado pelas malhas dos dispositivos terapêuticos a que é submetido, sem muita possibilidade de resistência a eles.

Aquilo a que não nos atentávamos era que, por necessidades desse próprio modo de trabalho, não se produz, a não ser com certa ingenuidade, um discurso sobre alguém, apenas. A bem do rigor, se produz um discurso com alguém ${ }^{11}$. Ora, senão seria aquela pesquisa mais um dispositivo a solapar as possibilidades de um "dizer" de "si" ${ }^{12}$, sempre no limite das possibilidades de fazê-lo. Essa constatação, ecos e retomadas da ideia de co-enunciação (Maingueneau, Aula - Sobre o Discurso e a Análise do Discurso, 2000; Guirado M. , 2000), redefiniu o rumo e escopo deste trabalho.

\section{Voltemos ao Projeto.}

$\mathrm{Na}$ época de sua escritura, insistíamos na distância e, até certo ponto, na não equivalência que haveria entre, de um lado, o quadro observável da" sintomatologia" e do "comportamento" de Daniel (para usar termos do discurso médico em questão) e, de outro, o diagnóstico que lhe fora conferido de Transtorno do Espectro Autista.

Assim, o Projeto de Pesquisa apresentava, em primeiro lugar, uma descrição do Daniel, onde o leitor se deparava com um retrato de o que chamamos de exuberância enigmática dos "sintomas" desse menino, que descrevíamos como puro corpo, ação e movimento, mas esfíngico para além disso. Incapaz de se comunicar, e talvez àquele

\footnotetext{
${ }^{11}$ Para uma discussão pormenorizada deste tema ver o Caso Ciro (Guirado M. , A clínica psicanalítica como análise de discurso, 2007)

${ }^{12}$ As aspas apontam para uma suspensão momentânea dos sentidos dessas palavras, que deveram ganhar novos contornos nesse trabalho.
} 
tempo (com 7 anos) também conformado, quem sabe um tanto desistente. Esse corpo puro ou essa intensa corporeidade gritavam nele; em parte, poderíamos pensar, eram ele.

É como se tudo fosse assim, tão perto e tão longe de entender o que dava origem a formas tão sensivelmente desconfortáveis, para ele, de comunicação. É como se fosse uma multiplicidade de motivos de toda ordem (neurológicos, afetivos, motores, cognitivos, fonoaudiológicos, familiares) que causassem uma espécie de curto-circuito e Daniel fosse acometido de uma apoplexia da comunicação, de o que ele sente "no corpo e na alma".

O efeito em quem estava perto (no caso, eu) era o de ficar com uma ânsia de entendimento, que também me deixava (e deixa, ainda) paralisado, em princípio. Não havia como ter notícia de o que Daniel sabia, sentia, pedia, podia, registrava... tudo ficava assim, um pouco paralisado na efemeridade do movimento de seu corpo. Apesar da contundência de seu olhar a transparecer sofrimento e desconforto em parte das vezes, e carinho e alegria, em outras.

Assim, no tempo das primeiras questões, acompanhados por uma ânsia de entender as razões desse quadro, quaisquer que fossem, questionamos o diagnóstico de autismo de Daniel. Não que ele não se justificasse, mas era (e é) incompleto nosologicamente, bem como insuficiente para instrumentar e direcionar um trabalho terapêutico. Isso levou a que se propusesse a discussão da questão diagnóstica em casos como esse, em que a constelação de sintomas, ações, comportamentos e atitudes é tão variada que parece resistir às palavras que nossa área do conhecimento tem para dizê-la.

Foi necessário, ainda no projeto, redefinir o uso do termo diagnóstico. Não como de ordem nosológica ou classificatória, mas de ordem descritiva, como um mapeamento 
dos discursos sobre (e de) Daniel ${ }^{13}$. Isso para abarcar o que pretendíamos fazer no estudo de caso que propúnhamos: uma descrição e um mapeamento dos modos de Daniel operar no mundo, se relacionar, interagir, aprender, se comunicar, se movimentar, etc. Atrelada a essa preocupação, defendíamos que para intervir em casos como o dele, era necessário ir além do autismo (ou de qualquer outro diagnóstico) e investigar não só os déficits, os sintomas, as dificuldades, as disfunções e alterações, mas os modos como, no conjunto de suas ações no mundo, Daniel os integra (os "déficits") em formas produtivas e até certo ponto novas de viver. Mais ainda, o que positivamente seus recursos significam no plano do desenvolvimento e como poderiam ser trabalhados. Essa propositura implicaria, inclusive, uma atitude do psicólogo no que diz respeito a seu lugar e "tarefa": não se trataria de educar e moldar o comportamento do paciente de acordo com um parâmetro externo a ele próprio, mas de acompanhar e desenhar qual o parâmetro do paciente, qual seu conjunto de referências, qual o seu "regime discursivo"; quais os pontos de partida, com o que ele e nós contamos para o trabalho. E intervir com base nesse quadro de possibilidades. Era importante também descrever quais os discursos sobre o paciente, qual a rede de dispositivos (médicos, familiares, científicos, educacionais, etc.) que atravessava, capturava e definia lugares para ele e para suas ações.

No entanto, acabamos com um projeto-dilema em mãos. Explicamos.

De um lado, ampliamos o uso do termo, talvez, para além de suas possibilidades, chegando a descaracterizar o "diagnóstico" como tal ou como poderíamos produzi-lo

\footnotetext{
${ }^{13}$ Esse ponto será retomado mais à frente, de modo mais direto, no Capítulo 3: Uma Historiografia
} Diagnóstica. 
contando com a realidade concreta de que dispúnhamos: especialidades médicas que não dialogam; abrangência e alcance de procedimentos; desconhecimento científico pontual para o momento (em que pesem as pesquisas empreendidas para solucionar o nosso desconhecimento); recursos dos familiares (financeiros e de disposição afetiva para tolerar tanta obscuridade) e assim por diante.

De outro lado, e contraditoriamente, uma ideia sub-reptícia (às vezes nem tanto) se revelava sempre que discutíamos aquela nossa proposta de pesquisa. A de que era preciso, necessário, refutar o diagnóstico de autismo. E, mais que isso, investigar até encontrar um diagnóstico médico que explicasse tão variado conjunto de sintomas. Nessas ocasiões, eram flagrantes nossas preocupações com as causas "orgânicas", neurológicas, genéticas e que tais.

Por esses motivos, suspendemos a ideia de diagnóstico, strictu sensu, como uma preocupação da atual pesquisa ${ }^{14}$. Ao menos, não seria mais seu objetivo principal.

No próximo item, voltaremos a tratar desse tema e do modo como, por exigências de contexto e de método, uma preocupação diagnóstica específica pôde ainda ser tratada no escopo geral da pesquisa, como uma historiografia dos dispositivos diagnósticos, por um lado, e pela ideia de "diagnóstico em ato", por outro. Tudo isso foi possível por uma restruturação básica do recorte da situação concreta que sustenta o trabalho, a saber: Daniel e seu acompanhamento. É por aí que iniciaremos o Tempo de mudança.

14 Embora uma melhor discriminação diagnóstica permaneça sendo uma preocupação em seu acompanhamento. 
Entre as primeiras questões de pesquisa e este trabalho que ora escrevemos, um movimento se anunciava no exercício concreto do trabalho com o Daniel: sem que necessariamente o percebêssemos ou o intencionássemos, ele vinha se traçando na instrumentação disciplinada de pensar com a visada da análise institucional do discurso. É um movimento de encontro entre essa estratégia de pensamento (AID) e a história de um menino e de seu acompanhamento. Vamos lá.

Como já dissemos, atender o Daniel é, às vezes, angustiante, pois nossa impotência anima uma sensação de deriva. Em outros momentos, retoma-se o prumo, embora o destino permaneça um tanto incerto. Sobretudo no que diz respeito às respostas que ele dará e aos avanços e limites de suas possibilidades de viver da melhor maneira que lhe for possível, agora e daqui em diante. As incertezas, pelo menos as irreparáveis, estão na dobradinha tempo/modos de viver.

Há, porém, algumas zonas de segurança, algumas balizas ou pontos de referência pelos quais é possível se orientar e organizar o pensamento e a ação. Já as esboçamos algumas páginas atrás, vamos agora especificá-las.

A primeira baliza é a constância do viés analítico, da estratégia de pensamento. O método da análise institucional do discurso é o terreno mais estável de nosso trabalho. Estável no sentido de uma presença insistente em todos os atos do exercício de nosso lugar como psicólogo e pesquisador. Ela instrumenta o pensamento desde o $(a$.) atendimento "ao vivo" até (b.) a organização das condutas mais gerais frente ao pequeno 
e sua família, bem como na $(c$.) caracterização dos lugares de seu diagnóstico, do $(d$.) lugar que ocupa nas falas de outros que com ele convivem e na (e.) produção desta pesquisa. Por ela, foi possível configurar um recorte e dar algum contorno aos trabalhos, acadêmico e de acompanhamento/atendimento de Daniel. Pela AID, inclusive, que se traçaram rotas que organizaram e organizam o pensamento. Sobretudo quando o pensar é ato; às vezes literalmente.

Por exercício de assim agir, Daniel e seu discurso, no contexto de seu atendimento, ganharam evidência, concretude, materialidade. Por escolha metodológica, as teorias (sobre autismo, sobretudo) foram suspensas, os entendimentos e sentidos que poderiam ser atribuídos instantaneamente às suas ações e comportamentos foram paralisados ${ }^{15} \mathrm{em}$ benefício de uma observação atenta dos movimentos e disposições dos (lugares dos) parceiros em cena. E tudo isso está escrito e previsto nos muitos trabalhos de Guirado sobre a análise institucional do discurso (Guirado M., 2010; 1986/2004; 1992; 2005; $2015 ; 2016)$.

Mais uma vez, como não estamos no campo das linearidades, essa disposição analítica - de uma analítica da subjetividade - não fez aparecer o verdadeiro Daniel, mas nos permitiu produzir um desenho possível (e possível porque de acordo também com os nossos "instrumentos" conceituais) de seus modos de ser, que são seu corpo e movimento. Assim, apesar das dubiedades, Daniel estava presente, a seu modo e força. Pujantemente

\footnotetext{
${ }^{15}$ No campo dos tratamentos do autismo afirmam-se muitas verdades, sobretudo no plano das intervenções, embora (e curiosamente) os conhecimentos produzidos pela pesquisa básica, principalmente aquelas relacionadas às "causas" do autismo, ainda estejam numa zona de incertezas. Ver para isso (Guirado \& Guirado, 2014).
} 
presente. Essa era a materialidade de seu discurso, além de qualquer dúvida: sua corporeidade.

Às constâncias do método e dos modos de ser somava-se outra, a dos nossos encontros. Como já dissemos, eles ocorriam, fizesse chuva ou sol, quatro vezes por semana, durante todo o ano, desde 2014 (e permanece assim até hoje).

Estava dessa forma montado o quadro, relativamente estável, desse atendimento. As suas "certezas", por assim dizer. Retomava-se um conforto mínimo, pois nunca se esteve (completamente) à deriva.

Com esse quadro em mente, voltemos, como prometido, à questão diagnóstica. Podemos dizer que a preocupação com um mapeamento diagnóstico, nos inícios do acompanhamento de Daniel, era um dos movimentos possíveis, no plano acadêmico, de tensionamento de uma situação concreta. Ou seja, mapeamento era o nome que demos à expectativa que, na cabeça desse psicólogo, tensionava a relação concreta de atendimento. Explicamos melhor com um curto exemplo.

Observávamos que Daniel, sempre que tivesse oportunidade, batia as palmas de suas mãos na maioria das superfícies a seu alcance, com certa força e obstinação, como quem quer fazer um barulho - poderiam ser tampos de mesa, assentos de cadeiras, bancadas, parapeitos, batentes. À nossa observação acrescentávamos perguntas e questionamentos: Por que é assim? O que o leva a fazer isso? Quais as relevâncias de perceptos para ele ao agir desse modo? A partir delas, levantávamos hipóteses (mais perguntas, no fundo): ele faria isso por causa do barulho que faz o tapa na superfície? Seria por conta da sensação tátil? Seria um automatismo/estereotipia que só serve como 
uma descarga de "energia"? Entre muitas outras possibilidades de "entender" comportamentos como esse. Essas perguntas, ideias e imagens passavam pela cabeça desse psicólogo, e, por isso mesmo, produziam efeitos na relação concreta de atendimento.

Seus efeitos mais diretos se organizaram como "testes clínicos”, intervenções, que eram realizados e que se acompanhavam seus efeitos: ora copiávamos seu movimento (ficávamos os dois, paciente e terapeuta, batucando nas paredes da escola); ora batíamos palmas bem alto no ritmo de suas batidas, de forma ao nosso som chamar atenção dele; ora fazíamos massagem em suas mãos; ora impedíamos o movimento de bater; ora procurávamos oferecer outros estímulos e sensações como substituição ao comportamento; e outras ainda. Intervenções essas, como se pode ver, das mais tradicionais às mais extemporâneas, das cognitivas às comportamentais. Mas, gostaríamos de apontar para o fato de que não estava em jogo a intervenção em si, e sim o efeito que provocaria sobre o Daniel, ou seja, como Daniel responderia a ela, o que ela produziria no movimento dessa relação terapêutica. E quando dizemos "efeito" sobre ele, não estamos nos referindo a um efeito específico, uma meta, um objetivo do tratamento, como por exemplo "que ele diminua a frequência de batidas de mão". Estamos nos referindo ao movimento, ou seja, às formas de ação que atingem e alteram em alguma direção aquilo que se repete nas ações do Daniel. Era o fundamental definir quais as formas de contato e comunicação podiam “enlaçar” o Daniel.

Retomando: Daniel agia, com os recursos e modos que lhe são possíveis e familiares. Este psicólogo, em ato, observava, pensava e agia (nem sempre nessa ordem), também com os recursos (técnicos, teóricos, conceituais, analíticos...) de que dispunha. Ação de um sobre a ação de outro, uma espécie de diálogo, ou a tentativa de um, (que se 
dava em diversos níveis, não necessariamente o da palavra e da fala, embora "falar" fosse uma ação prevista e corriqueira de nossa parte). Um atendimento que, assim, permanecia aberto. Aberto ao sabor de cada dia, do humor e estado de Daniel, também de meu humor e estado (muito mais constantes), das ações dos parceiros em cena e de suas respostas, às vezes inusitadas, das mudanças dos lugares de enunciação, que comportavam inclusive mudanças na "regra do jogo" e uma reacomodação constate de nossas ações... Enfim, um discurso que se fazia a cada dia, a cada ato, no encontro face a face dos parceiros de trabalho.

De tal modo que, "no calor da hora", num dia ordinário de trabalho (meu e dele) eram dadas respostas de um lado e de outro, ações repetiam-se, resistiam, uma relação se instituía, numa dinamicidade e vivacidade que se tornaram características deste discurso e desse modo de trabalhar. Intervenções feitas, aprendizados se viabilizavam ou naufragavam, rotinas criadas, rearranjos de tempos e espaços produzidos, e muitos outros movimentos faziam parte do miúdo do dia-a-dia do atendimento. E que fique claro e registrado que não se tratava de improviso ou leviandade, como a expressão "calor da hora" pode ensejar, mas de uma cuidadosa atenção à situação concreta e ao contexto, que exigiam por vezes respostas novas e quase nunca "padronizadas". Isso tudo era e é feito por método.

Assim, na "cena originária" a preocupação diagnóstica (instrumentada por um método de pensamento) foi o disparador do trabalho. No entanto, o próprio exercício do acompanhamento de Daniel fez do trabalho um ato vivo e dinâmico. Produziu-se, nessas e por essas regularidades, um discurso e uma relação vivos, ocasião de produção de 
sentidos contextuais (como sempre são os sentidos ${ }^{16}$ ). Esse discurso, o do acompanhamento do Daniel, tornou-se soberano, porque era construído a várias mãos, coproduzido pela parceria entre ele e eu. Parceria que, constituída no limite tenso de um exercício de pensar cada movimento dos parceiros em cena, por estratégia, posicionou $o$ Daniel no centro da cena. A AID, portanto, o colocou em evidência. Ela foi a bússola que apontou o caminho do trabalho. E o caminho era ele. Não tinha outra saída. O que fez toda a diferença.

Fez diferença considerar isso porque exigiu que a escritura dessa pesquisa se tornasse também viva e dinâmica, como os movimentos do trabalho terapêutico e os movimentos próprios do Daniel. Qualquer que fosse o caminho que se abrisse, ele seria resultado de uma configuração possível do discurso, dispositivo e contexto desse acompanhamento.

Assim, pela análise institucional do discurso se tornou possível manter alguns termos e ideias e outros simplesmente deixar que fossem mostrados na medida de sua urgência, pela própria história do Daniel e dos movimentos de sua vida ${ }^{17}$.

O termo “diagnóstico" é um deles. Foi importante considerá-lo, porque quando se lida no limite de uma configuração de sintomas como os desse menino, é necessário saber mais algumas coisas, sobre suas causas, motivos e configurações, orgânicas inclusive. No entanto, nem sempre essas respostas foram dadas, ou não tínhamos com exatidão as

\footnotetext{
16 Ver Maingueneau (Maingueneau, 1989; 1995; 2000)

17 Passamos, com aparente leviandade, do "contexto do atendimento" para a vida. Ao longo do trabalho isso ficará claro. Por hora adiantemos que, pelas próprias características específicas da situação em questão, o acompanhamento de Daniel era um acompanhamento de sua vida e na sua vida. $\mathrm{O}$ atendimento não se colocava como um a parte.
} 
respostas de o que é que se passa no plano neurológico e psiquiátrico, especificamente. E saber dessas "causas" fica ainda mais difícil quando se está em determinado contexto familiar, como se verá no capítulo de historiografia.

No entanto, não se abandonou por completo a perspectiva de buscar "diagnósticos" (no plural). O que se arrefeceu foi a idealidade de encontrar um diagnóstico único, uma síndrome ou algo equivalente, centralizador de todos os sintomas. Fato é que, pelo próprio acompanhamento de Daniel, por nossas observações, por seu corpo sempre ativo e de uma presença avassaladora, diagnóstico e intervenção misturavam-se no exercício cotidiano de um acompanhamento terapêutico cuja história é viva e dinâmica. Falar em diagnóstico se tornou obsoleto, para não dizer equivocado. "Diagnosticava-se" e intervinha-se em cada situação apresentada, a cada ação nova de Daniel, a cada reação, a cada repetição, a cada momento. O termo diagnóstico se implodiu como descritor desse modo de trabalho e desse acompanhamento, no ato mesmo de seu exercício.

Na contrapartida, a situação concreta do atendimento exigiu uma espécie de "diagnósticos em ato", que acabaram se configurando como dispositivos que fornecem direções para o tratamento e para a intervenção. Assim, o acompanhamento diário e atento de Daniel "provocava" pensar em hipóteses variadas e específicas - sensoriais, cognitivas, comportamentais, neuropsicológicas, fonoaudiológicas, ortopédicas, motoras, neuromotras, etc... - que viabilizassem intervenções terapêuticas ajustadas para as necessidades dele. A buscar assim outras formas de facilitar as condições de vida dele, à medida que ele vai crescendo e precisando entrar em contato com o mundo, e tendo ainda como referência e sensor o próprio corpo, que por isso restringe, até certo ponto e em muitos aspectos, sua comunicação. 
Esse movimento de alteração da perspectiva e da função do diagnóstico é que organiza e dá sentido ao próximo capítulo, Daniel: uma historiografia diagnóstica. Nele a marca dessa alteração transparece na escritura, e por isso o dividimos em duas partes, cujos "estilos" discursivos são completamente diferentes.

$\mathrm{Na}$ primeira delas, nos apoiamos na ideia de dispositivo institucional ${ }^{18}$, que facultou desenvolver uma análise que desenha o contexto da produção, dos movimentos e tensões das relações institucionais em jogo na configuração do diagnóstico psiquiátrico de autismo para Daniel. Dessa forma, pudemos preservar o caráter analítico do trabalho, evitando o engodo de refutar o diagnóstico médico. Isso implicou dar relevo aos dispositivos de produção diagnóstica, de dinâmica sui generis nesse caso, e aos efeitos sobre os alvos de seu exercício, a clientela.

Na segunda parte da historiografia, fica claro o movimento seguinte a esse, que é o de "buscar" o que mais "além de autismo" é possível dizer sobre Daniel. Para isso, entram em cena discursos de outros profissionais e especialistas que, por diversos motivos, "tinham o que dizer" sobre ele. Com esses discursos, produziu-se uma espécie de mosaico, para dizer do Daniel de modo mais individualizado e específico possível.

\footnotetext{
${ }^{18}$ Segundo Foucault : “Através deste termo tento demarcar, em primeiro lugar, um conjunto decididamente heterogêneo que engloba discursos, instituições, organizações arquitetônicas, decisões regulamentares, leis, medidas administrativas, enunciados científicos, proposições filosóficas, morais, filantrópicas. Em suma, o dito e o não dito são os elementos do dispositivo. O dispositivo é a rede que se pode estabelecer entre estes elementos. [...] Em segundo lugar, gostaria de demarcar a natureza da relação que pode existir entre estes elementos heterogêneos. [...] Em terceiro lugar, entendo dispositivo como um tipo de formação [...] teve como função principal responder a uma urgência" (Foucault M. , 1978/2010, p. 244).
} 
Como podemos ver, as perguntas de pesquisa iniciais ganharam outro contorno e lugar no presente trabalho, ficando circunscritas a um de seus capítulos (o terceiro, nesta Tese).

No item seguinte apresentaremos o que mais será esse trabalho, além de uma historiografia diagnóstica. Nele, trabalharemos algumas derivações das ideias até aqui apresentadas, analíticas e conceituais, que nos levaram à produção da presente pesquisa na forma de uma analítica da subjetividade.

O tempo da escritura atual

Como uma derivação da AID, ou melhor, das análises contextuais que ela permite produzir, outros conceitos ou ideias tornaram-se importantes para este trabalho. Apresentaremos em tópicos (sem títulos) apenas para facilitar a exposição.

1.

A relação entre corpo, sentido e comunicação pôde ser pensada como uma marca possível de o que caracteriza Daniel. Tudo indica que seja a presença corpórea o que viabiliza o estabelecimento de algum sentido (qualquer sentido); Daniel é corpo e movimento. E todo o sentido possível para a comunicação é disparado por e no seu corpo. 
Esse mesmo corpo é que dá o limite. Melhor dizendo, os limites. E, como ele é o instrumento de agir do Daniel, é também o conjunto de suas (im)possibilidades. De imitação, de comunicação, de aprendizado, de memória, de relação...

2.

O termo atendimento também precisou ser "reacomodado". Tradicionalmente, ainda que as tradições estejam em constante tensão, pensam-se e operam-se, em ato, atendimentos psicológicos a uma determinada clientela. Essa clientela, em geral, é que figura no foco de luz e relevo das intervenções do psicólogo ${ }^{19}$, é alvo delas. E isso é assim ainda que se considere essa clientela como agente ativo, a contribuir ou resistir, no trabalho terapêutico.

Sutilmente diferente, mas de implicação concreta relevante, é considerar o psicólogo e seu trabalho como parte, imprescindível e inalienável, do discurso e contexto do atendimento. Isso quer dizer que o fazer concreto do psicólogo carreia sempre e a cada encontro e situação de atendimento o leque de expectativas de exercício e funcionamento dessa instituição, bem como suas teorias e/ou métodos, os procedimentos de análise e pensamento, as expectativas e imagens sobre a clientela e seu "quadro clínico", entre outros $^{20}$. Pensar assim implicou considerar que paciente e terapeuta produzem o discurso

\footnotetext{
${ }^{19}$ Isso independe do nome que se dê ao procedimento de intervenção, que, como sabemos, varia entre as diversas linhas de pensamento de nossa psicologia. Interpretação, modificação de comportamento, modelagem, aprendizagem, são alguns deles.

${ }^{20}$ Sobre as "imagens e expectativas" a respeito da clientela, ver, principalmente, O Caso Clóvis constante do livro Análise do Discurso e Psicanálise (Guirado M. , 1995/2018). Ver também: (Lima, 2007; Viaro, 2011).
} 
do atendimento, produzem o próprio atendimento. Paciente, terapeuta e atendimento não são, portanto, parte extra parte, mas configuram-se e exigem-se mutuamente.

Em nosso caso, especificamente, o atendimento foi tensionado e construído na e pela singular incomunicabilidade e potente corporeidade de um dos parceiros em cena. Este, onde quer que fosse ou com quem se relacionasse, carregava consigo esses signos opacos de sentido ao interlocutor, ao terapeuta e aos outros. Era mister, portanto, fazer circular nos âmbitos diversos da vida do Daniel os poucos, mas constantes, sentidos que no contexto de nossa relação produziam-se. Era uma forma de fazê-lo falar falando dele. Em pouco tempo, o discurso do atendimento alargou-se como um discurso possível, de autoria do Daniel, e não apenas sobre ele; autoria essa que ele compartilhava comigo. Assim, esse discurso é como uma narrativa possível da própria história ${ }^{21}$, em contexto e situação tão adversos. Por isso, desse ponto em diante, considerando o carácter inextrincável dessa dupla de trabalho, usaremos o termo acompanhamento e não mais atendimento.

Há aqui mais uma característica a se acrescentar sobre a relação entre comunicação e contexto. Para Daniel a comunicação envolve apenas uma pessoa, não o contexto, de tal forma que, para ele, essa pessoa (com quem por vezes é possível se comunicar) torna-se o contexto. Pelos motivos apontados até aqui, de certa forma, eu ocupei esse lugar e papel de "intérprete", interlocutor e contexto dos gestos e movimentos, muitas vezes erráticos do contato do Daniel com o mundo e deste com ele.

\footnotetext{
${ }^{21}$ A autoria dessa belíssima frase é de Marlene Guirado, a quem pedimos licença de uso. Ver: Acolhimento em Abrigos: direito à construção de narrativas da própria história (Guirado M. , 2016 )
} 
3.

Por fim, nesse tópico faremos considerações acerca de alguns operadores conceituais que nos permitem aventar uma hipótese que sustentará a trilha desse trabalho. Comecemos pelos conceitos: memória e singularidade.

[...] outra maneira de tratar do inconsciente: registros das experiências, em rede, mediante a inscrição num complexo de memória (inconsciente), ao modelo dos registros em um dispositivo especial, chamado bloco mágico, à época. (Guirado M., 2010, pp. 126-127, grifos nossos)

Dessas palavras de Guirado sobre o texto Uma nota sobre o bloco mágico (Freud, 1925/1976), gostaríamos de resgatar, neste momento, seu valor como descritor de um modo de pensar as relações entre memória e singularidade.

Guirado caracteriza esse texto (Freud, 1925/1976) como uma das "aberturas" do discurso de Freud, que juntamente com $O$ estranho (Freud, 1919/1976) seriam "modos díspares e a ao mesmo tempo confluentes" de tratar/pensar o inconsciente (Guirado M. , 2010). Diz ela que Freud faz uso da descrição do dispositivo chamado por ele de "bloco mágico" como um modelo para entender/explicar o aparelho psíquico e seu modo de funcionamento. Apresentaremos resumidamente o que é esse dispositivo e uso que Freud faz dele, mas não nos filiaremos à concepção desse autor.

Segundo ele, o bloco mágico é constituído de três camadas, a primeira, de baixo para cima, é uma placa de cera, seguida de um papel de seda (segunda) e depois de uma película de celuloide (terceira camada); todas estão afixadas em uma das extremidades da placa de cera, de modo que podem ser suspensas a qualquer momento. "Com um objeto 
pontiagudo, grafa-se sobre o celuloide qualquer traço [...] o que se grafa permanece decalcado no papel de seda, pela pressão feita sobre a cera” (Guirado M., 2010, p. 127). Tal grafado pode ser "apagado" do papel de seda pela simples suspensão das folhas, apagando-se o registro nessa superfície e liberando o dispositivo para novos traçados. No entanto, as marcas na placa de cera permanecem, embora só fiquem aparentes sob certa incidência de luz. A analogia freudiana com o aparelho psíquico é a de que a camada de celuloide, que funciona como uma proteção à seda, seria o equivalente ao nosso limiar de percepção a proteger nosso aparelho perceptivo-consciente. A camada de seda seria o aparelho perceptivo-consciente e a placa de cera, o inconsciente como a memória possível. Freud continua sua analogia descrevendo os mecanismos de repressão e a “pressão” exercida pela camada de cera (Freud, 1925/1976 em Guirado M., 2010).

Nesse ponto, deixamos Freud. Sigamos com Guirado 22.

A autora dá destaque à analogia entre cera, inconsciente e memória. Ela aponta que se inconsciente é memória, então é algum tipo de registro e de marca. Assim, o registro na cera (memória), apesar do "apagamento" da percepção "consciente", permaneceria, como um sulco ou decalque; de forma que, pode-se pensar, vida a fora, outros registros e marcas são feitos e o efeito na superfície da cera é da produção de uma rede de registros sobrepostos, justapostos, transpostos. Essa rede, por sua vez, exerceria pressão e "alteraria" a inscrição dos novos traços. Assim, afirma Guirado, por essa analogia, "a vida é a história desses decalques em tramas, cenas e enredos cada vez mais

\footnotetext{
${ }^{22}$ As ideias de Guirado que trataremos na sequência são derivações possíveis apoiadas no discurso de Freud, mas não encontram-se textualmente na escritura freudiana.
} 
complexos, onde a cada nova experiência temos a retroação das anteriores, bem como a modificação delas. A vida é um bloco mágico...” (Guirado M., 2010, p. 127).

Assim, a história (singular) de alguém, pode ser pensada e desenhada no ponto de tensão entre a pressão dos decalques/marcas dos registros anteriores e as condições e configurações de contexto e relação atuais. A ideia do bloco mágico como esse registro em rede de cenas e enredos, a constantemente se modificar e modificar a situação presente, é uma metáfora do modo de pensar a singularidade matizada pelas e nas relações institucionais e dispositivos discursivos. Isso porque, por pressuposto, considera-se que há, nas relações que estabelecemos em nossas vidas, uma "negociação", um "acordo", constante entre os lugares que nos vimos ocupando nas relações anteriores e os lugares que ocupamos presentemente para a configuração da relação institucional ora em exercício (Guirado M., 2010).

Uma análise que parta desses pressupostos será como um desenho possível, num contexto específico, de uma história, também, possível de um si.

Nesse (nosso) caso, o Daniel, "sua" história e "seus" modos de ser seriam esse desenho possível. E as aspas denunciam justamente esse arranjo em rede, pluriforme e caleidoscópico, dos registros e marcas, muitas vezes sem autor ou sujeito, da história da vida desse menino, cuja incomunicabilidade não o privou de se relacionar com os outros em contextos institucionais diversos, não o privou de um exercício singular de um lugar institucional. Será tarefa de nosso texto, como pesquisa, a narrativa dessa história na indeterminação dos emaranhados da rede desse bloco mágico de sua vida.

Mas, as aspas denunciam ainda mais: vida e história são termos que devem ser tomados em seus recortes de contexto e instituição. A saber, o acompanhamento que faço de Daniel: não há unicidade, não há a história real e última desse menino; o oposto 
tampouco é verdadeiro, não há versões, sem fim, de sua história. O que há é uma história construída em e por um contexto, específico, no exercício de relações vivas, dinâmicas e singulares que constituem e configuram o acompanhamento terapêutico de Daniel.

Acompanhamento este que se movia e movia diversos registros discursivos, em diversos níveis. Por exemplo: de nossa parte, havia $a$. um emaranhado de expectativas e imagens sobre o Daniel "concreto", sobre suas ações e atitudes; $b$. havia, em outro plano, conjuntos de "estudos" e hipóteses que carregávamos da psicologia e da neurologia para pensar sobre ele; $c$. havia os relatos que diariamente fazíamos sobre o dia dele para seus familiares; $d$. havia os relatos que nos eram feitos por outras pessoas, bem como suas hipóteses sobre ele e o que entendiam/interpretavam de seu modo de agir; entre outros. Todos esses são discursos, registros e marcas, como sulcos ou decalques do bloco mágico do acompanhamento, traçados em rede uns sobre os outros. Esse é o caleidoscópio, o objeto de análise e atenção neste trabalho.

E mais uma vez, as palavras de nossa orientadora vêm dar sentido a este trabalho; a hipótese que prometemos apresentar alguns parágrafos acima nos foi apresentada por ela, e posiciona-se agora como a tese central de nossa pesquisa. A saber: Daniel também faz registros, deles compõe memórias em rede, que carreia, como "expectativa", nas novas relações que estabelece vida a fora. Ele também traz consigo a memória marcada das relações que viveu e vive; é o bloco mágico do Daniel. Por isso, apostamos que, além 
de nós, ele também preserva uma história de si. Sem palavras como as nossas, que possa nos falar... ${ }^{23}$

É sobre essa "aposta" que o presente trabalho se estrutura como o desafio de uma análise institucional do discurso do Daniel; uma analítica da subjetividade.

Da organização do texto

Ele está organizado de uma Abertura e deste capítulo, como se viu até aqui, e será seguido de três outros, intitulados: Sobre Daniel: uma descrição exemplar, Uma Historiografia Diagnóstica (de que já falamos acima) e Corpo, movimento e sentidos. Ao longo do texto, o leitor será avisado sobre a razão e motivo do encaminhamento para o capítulo seguinte.

Em Sobre Daniel: uma descrição exemplar apresentaremos ao leitor um "retrato bruto" desse paciente e do contexto do acompanhamento terapêutico, de tal modo que se possa formar uma ideia preliminar e introdutória sobre os alvos de nossa atenção nessa pesquisa, à qual poderemos recorrer sempre que for necessário

${ }^{23}$ Certa vez, realizamos um passeio a uma loja de materiais esportivos na Zona sul de São Paulo. Daniel, quando criança, morou naquela região por alguns anos. Enquanto, de carro, passávamos pelos prédios e casas no caminho, seus olhos pareciam acompanhar cada detalhe da paisagem, como que "escaneando" o espaço. Sua mudança de atitude foi tão radical que no momento foi impossível não pensar que ele também procurava dentro de si reencontrar aquelas imagens, provavelmente familiares. 
Corpo, movimento e sentidos é o capítulo principal desta tese, nele entramos de vez na análise da história do Daniel, de sua vida e de seu acompanhamento. Nele, já orientados por nosso recorte analítico, daremos foco aos índices fortes e característicos da presença de Daniel nas relações que estabelece e nos modos de ser/agir. Esses índices são seu corpo e corporeidade, como o instrumento e a forma de contato e relação; seu movimento como um de seus únicos modos de expressão e viabilidade de toda e qualquer ação em toda e qualquer ordem, de seus afetos/desafetos, de seus entendimentos/desententimentos, de suas dores e "angústias", de sua alegria e "plenitude"; todos esses considerados como modos de dizer e fazer seus vínculos. Trataremos, por decorrência de assim pensar, do(s) sentido(s) que é possível resgatar e produzir em e por esse modo tão concreto e efêmero de ser.

Nesse capítulo ainda, trataremos de eventos da vida de Daniel que, por seus efeitos e por uma observação e análise de contexto, foram ocasião de produção de alguns entendimentos e sentidos, nem sempre positivos, mas certamente relevantes. Um deles, por exemplo, føi a suspensão de uma medicação, "na calada da noite", sem aviso prévio ou preparo, por decisão dos pais. Embora Daniel não fale, seu corpo deu notícias sobre o que estava acontecendo, o que permitiu configurar o lugar e a função, ainda que gerais, de um tratamento medicamentoso, que lhe permite desfrutar, no limite, algumas de suas possibilidades.

Está assim organizado o "texto principal”. Como se vê, este trabalho não terá, portanto, uma conclusão. Sentimos, com isso, ter frustrado ou até enganado o leitor prometendo uma peça acabada, com começo, meio e fim. Entendemos isso.... No entanto, optamos por esse desenho pouco usual para um trabalho de pesquisa, porque o caso em questão, bem como o acompanhamento que fazemos dele, têm, por diversos motivos e 
contingências, uma configuração também muito específica, de tal forma que se buscou respeitar essas idiossincrasias na escritura final. 


\section{Capítulo 2.}

\section{Sobre Daniel: uma descrição exemplar}

Selecionamos para esse capítulo cenas exemplares de Daniel e de seu acompanhamento terapêutico. Por "exemplares" entenda-se: $a$. as recorrências e repetições nos modos de ser e agir de Daniel, que se estendem ao longo do tempo, dos espaços e dos contextos ocupados por ele; $b$. por outro lado, aquilo que foge às regularidades, o inédito, que por isso mesmo torna-se relevante.

Iniciamos o acompanhamento de Daniel em fevereiro de 2014. No contrato inicial, nossa função seria a de orientar a tutora que o assistia na escola. Assim, passávamos de uma a duas tardes por semana com ele e ela na instituição de ensino. Observávamos a rotina, o Daniel e sua tutora e orientávamos sobre as formas de intervir e sobre as alterações necessárias de rotina e de procedimentos, no limite de todas as carências de contexto, que não eram poucas: de um lado, uma escola pouco profissionalizada e com metodologia de ensino pouco consistente; uma desinformação total sobre inclusão, práticas inclusivas e crianças "de inclusão"; falta de recursos e de materiais adaptados; do outro lado, um Daniel cujas dificuldades pareciam não ter fim, cujos sintomas estavam obnubilando sua "personalidade".

Mesmo assim, nessa época, viabilizaram-se algumas alterações básicas (quase basais). Conforme observamos, Daniel tomava o lanche na sala dos professores, não o fazia no pátio como e com as outras crianças; ele ficava em sala por tempo ínfimo, mesmo assim, ocioso, não se lhe propunha qualquer atividade, ele andava pelo ambiente, girava 
as cadeiras (sim, as cadeiras!), corria para fora, batia palmas...; era levado muitas vezes ao dia, por tempo indeterminado, à piscina de bolinhas, e lá ficava, sob o olhar da tutora; a única atividade que se preparara para ele era a de colocar canudos em buracos de uma caixa de papelão, que realizava com certa facilidade, mas sempre na sala dos professores, que era fisicamente muito diferente das salas de aula. Muito se alterou nessa rotina, com nossas intervenções, no sentido de fazer do Daniel parte da escola, e não um aluno que era levado para ambientes onde mais parecia ser despejado e contido, sempre aparte do funcionamento do "resto" da escola. Tudo indicava que, independente das intenções (no geral boas em relação a ele), Daniel estava fora da "ordem institucional", e não apenas pelo conjunto de suas “inadequações", mas pelo modus operandi da própria escola.

Nesse sentido, é que se alterou o uso do espaço pelo e com o Daniel. A sala dos professores, por exemplo, não é ambiente frequentado rotineiramente pelos alunos, apenas em situações especiais, por que o era por ele? Por que ele tomava seus lanches lá? Por que fazia sua única atividade do dia lá? As respostas a essas perguntas variavam: "é porque é mais calmo para ele"; "é porque ele pega o lanche das crianças"; "é porque ele chora muito (e atrapalha, isso não diziam)"... Tudo parecia indicar, nas falas e ações dos funcionários, que Daniel não se encaixava no que era o "padrão". Pois bem... Traçamos estratégias para controlar e contornar essas dificuldades sem que para isso Daniel precisasse ser movido, deslocado fisicamente para esse ambiente recluso e "protegido" (que protegia o Daniel ou, do Daniel?). Assim, ele poderia usar o espaço do pátio para tomar o lanche, o da sala para fazer as atividades e convivência, como todos, ainda que não o fizesse "como todos".

Em 2015, por uma constelação de motivos que não cabe nesse momento apresentar, assumi integralmente o acompanhamento de Daniel. Não mais como 
orientador, mas como psicólogo a serviço diretamente dele. Por um enquadre de acompanhamento terapêutico, passei a acompanhá-lo quatro vezes por semana, quatro horas por dia, que correspondia a todo o período que ele permanecia na escola. Nessa época, algumas alterações já haviam seguido curso, mas minha presença, ao que parece, foi fundamental para mantê-las.

Como dissemos, foram alterações basais na organização geral do espaço e do tempo do Daniel na escola, iniciadas em 2014 e que se consolidaram no início de 2015. Assim, na medida do que fosse possível, Daniel passaria a habitar os mesmos ambientes ocupados pelas outras crianças de sua turma: a sala de aula, o pátio, a quadra de esportes, o banheiro (de alunos, não o de funcionários), o refeitório, o parquinho. Preferencialmente nos tempos e horários em que essas crianças estivessem lá. De tal forma que ele, no mínimo, estivesse junto, fisicamente, com seus pares. Não implicava com isso que Daniel seria privado ou impedido de frequentar certos lugares, mas de evitar a curiosa e recorrente equação "O Daniel está onde ninguém mais está", em outras palavras, ele e as crianças quase nunca estavam juntos. Segue em tópicos essa organização:

1. Daniel chegaria à escola e, como os outros, ficaria liberado para usar o pátio da forma que desejasse: corria, ia até as janelas e batia em seus parapeitos, andava em diferentes direções, quase nunca sentava.

2. Ao final desse período, ele, como todos seus colegas, se direcionaria para a sala de aula.

3. Lá, realizaria algumas atividades. No caso do Daniel, nesses primeiros momentos, não era sobejamente relevante $o$ que ele faria, conquanto fizesse em sala, na presença dos colegas. Assim, propunham-se atividades lúdicas e mais prazerosas, 
e lhe era facultado também circular pela sala de aula. Por vezes algum colega se aproximava e brincava com ele.

4. Como esse período em sala se estendia por quase duas horas, um tempo sem fim para ele, por vezes era concedido ao Daniel passear um pouco pela escola, podendo ir ao parquinho por alguns minutos, ao banheiro, beber água, cumprimentar alguns funcionários. Depois dessas saídas, voltava para a sala e para o grupo.

5. No meio da tarde havia a "hora do lanche", o intervalo dos alunos. O Daniel descia com as crianças e subia com elas na volta para a sala. No pátio, sentava-se à mesa em que os colegas estivessem. De fato, ele pegava os lanches dos outros se não fosse impedido. Mas, curiosamente, isso não afastou as crianças, pelo menos a maioria delas. Algumas trocavam lanches com ele, outras protegiam os seus e, "de quebra", ainda tentavam explicar para ele que não podia "pegar o lanche do coleguinha". Em pouco tempo, ele aprendeu a se controlar minimamente, embora lanches muito apetitosos fossem uma tentação à parte.

6. Voltava para a sala e lá permaneceria, como descrevemos nos pontos 3 e 4.

7. Frequentava também as aulas extraclasse normalmente: ia à capoeira, à educação física, à aula de música. Lá, faria o que pudesse, quisesse, conseguisse...

Em pouco tempo, Daniel (que contava com sete anos nesse período) passou a ser parte da sua turma. Na época, em nossas anotações, escrevemos que ele passou a ocupar e exercer, no limite de suas possibilidades, o lugar de aluno de uma escola. Era o Danielaluno. E assim era visto também pelos colegas, que estranhavam e perguntavam onde ele havia ido que não estava na aula de educação física, por exemplo. O lugar a seu lado na 
mesa do lanche era disputado pelas crianças (sobretudo as meninas). Outras vinham nos perguntar se ele queria/podia ir brincar de pega-pega ou de polícia e ladrão no intervalo. Recebeu inúmeras cartas e desenhos dessas mesmas crianças, retratos do carinho que dava e recebia.

Por efeito de uma reorientação do uso do espaço e do tempo do Daniel na escola, ele tornou-se conhecido e reconhecido pelas crianças e, supomos a partir de suas expressões de prazer e contentamento, conhecedor e reconhecedor delas. Daniel ganhou existência concreta no e pelo convívio com os outros. Antes, dele as crianças só tinham notícia à distância, como o menino que perambula pela escola, fica na sala dos professores e na piscina de bolinhas, que não tem sala, turma ou... amigos. Aquele que "sempre chora" e não fala.

Das alterações basais passamos para intervenções mais específicas. Nesse ponto, mudaremos também o foco desta apresentação. O leitor deve ter notado que até agora não falamos muito sobre o Daniel propriamente, e sim da escola, de seu funcionamento, das crianças, dos funcionários, em resumo, dos movimentos e lugares institucionais. É que, até esse momento, o Daniel "não existia" para a escola.... não existia como lugar de enunciação, não tinha voz e ação de que compartilhassem interlocutores (Guirado \& Guirado, 2014). ${ }^{24}$ Por isso, seria injusto, de minha parte, como pesquisador, falar $d o$ Daniel em si, quando em condições de contexto e ambiente tão excludentes e marginais como aquelas em que o conhecemos.... Falar dele (e só!) seria repetir tais segregações.

\footnotetext{
${ }^{24}$ Nos termos de Foucault, era a face de uma teratologia nas práticas de ensino (Foucault M. , A ordem do discurso, 1971/1996).
} 
No entanto e infelizmente, esse funcionamento por segregação não foi algo esporádico em sua vida, merecendo, portanto, um espaço entre o que é "exemplar".

Agora podemos falar um pouco mais sobre Daniel, de certo modo, incircunstanciado. Essa condição de nossa escritura faz referência a seu próprio estilo: nesse momento do texto daremos destaque àquilo que se repete, renitentemente, na ação e no comportamento de Daniel, desrespeitando variações de ambientes, contextos e pessoas. Há certos traços gerais no modo de ele ser que resistentemente, no tempo e no espaço, marcam sua atuação e ação no mundo. Vamos a eles.

\section{Fala}

Daniel não fala. Ao longo de alguns anos de nosso acompanhamento, apenas duas vezes foi possível discriminar algo próximo de uma palavra ${ }^{25}$ : "areia” (que ele disse a-ei-a, como quem canta uma música) e "não" (ão) ${ }^{26}$. Apenas isso é que pudemos observar ${ }^{27}$. Muito embora ele tenha voz e emita sons frequentemente (quando ri, quando chora), ela parece sair involuntariamente nessas horas, como um efeito colateral de outras ações.

\section{Movimento}

Daniel não para. Está perenemente em movimento: quando em pé, anda de um lado para o outro, às vezes dispara em corridas. Quando sentado, os dedos não sossegam, estão sempre a girar objetos, qualquer objeto. As palmas de sua mão estão sempre vermelhas ou calejadas, pois bate com elas na maioria das superfícies, sobretudo batentes de janelas;

\footnotetext{
${ }^{25}$ A vocalização não é clara, é uma espécie de canto entoado.

${ }^{26}$ Semanas depois da escritura desse texto, Daniel falou, de modo claro e articulado, a palavra "não".

${ }^{27}$ Outras pessoas relatam falas como essas, mas são sempre ocasionais e não se repetem, ainda que se peça a ele que o faça.
} 
sem sentido aparente, a não ser o de bater, simplesmente. Por alguns períodos, apenas, é que pode diminuir a intensidade desses movimentos, em geral sob medicação ou quando está muito cansado, mesmo assim, não é algo que se possa registrar sempre; diminuíram, isso sim, ao longo dos anos, as expressões de desagrado e de desconforto associadas a essa "agitação (com o uso de medicamentos psicotrópicos).

Ele é grande, maior que os garotos da mesma idade (está hoje com 11 anos). E parece ter ainda mais, pois anda sempre na ponta dos pés.

Sem dúvida, as mãos e corpo inquietos e a ausência de fala são suas maiores marcas. Quem é o Daniel? O menino que não fala e não para.

\section{Choro}

Daniel chora, às vezes copiosamente, e como se fosse um bebê, ficamos todos ao redor procurando interpretar "o que", "por que" chora.

Quem mais de perto convive com ele, aprendeu a ler alguns sinais de desconforto. Muitas vezes essa "interpretação" é de que está com fome, ou de que está com vontade de ir ao banheiro, ou de que é alguma resposta ao impedimento de sua ação. Mas ainda mais frequente, de que está com algum tipo de dor, sobretudo quando leva as mãos e bate na sua cabeça.

\section{Intensidade e força}

Dissemos em outro lugar, Daniel é intenso e forte, na "alma" e no "corpo". Suas demonstrações de afeto, que se mesclam a uma autoestimulação, também são assim: fortes. Quando está muito animado, por exemplo, abraça a pessoa querida e leva sua cabeça até seu próprio peito, ou dirige seu antebraço à boca dessa pessoa, para que ela lhe dê "mordidinhas". Não há limite para essas expressões, ele agarra os cabelos, usa toda 
sua força para puxar; e cabe à pessoa, alvo e agente do carinho, prover o controle necessário à situação, evitando que ele e ela se machuquem. Mesmo assim, são frequentes pequenas lesões: uma mordida mais forte aqui, um arranhãozinho ali.

Com a mesma força que vem o prazer, vem a dor. Quando Daniel chora, é como um grito fundo e sem fim. Seus músculos se enrijecem, suas cordas vocais parecem que vão romper e sua pele, extremamente branca, avermelha-se e estoura de calor. E isso é mais frequente do que se desejaria. Em situações-limite, não há contenção física ou afetiva que lhe dê conforto; a impressão é que não há o que o fará parar de chorar até que o cansaço desse esforço caia sobre ele.

A maioria de suas expressões e comportamentos são imediatos. Se vê um doce, ele pega e leva à boca. Se vê algo que parece interessá-lo, desenlaça-se de qualquer impedimento e vai até lá. Se "quer" um carinho no peito, abraça e ponto (às vezes esmagando alguns óculos, derrubando objetos e alimentos que estejam no caminho). Se “quer" correr, corre. Se "quer" pular, pula. Se vir água, se molha. Sem aviso e sem sinal, ele se lança, abrupta e subitamente, a essas sensações e experiências.

\section{Sensações}

Aliás, essa é uma outra característica de Daniel. Seu universo parece ser constituído basicamente por "sensorialidades". O seu mundo é aquele que suas mãos, olhos, boca e nariz alcançam e sentem. Por exemplo, quando fomos, certa vez, cozinhar biscoitos, toda tarefa que lhe era proposta (apertar a massa, usar forminhas para fazer formas de biscoito, usar o rolo, etc.) eram substituídas por uma única ação: pegar qualquer pedaço de massa (crua) que estivesse a seu alcance e levar à boca.

\section{Sentimentos}


Em meio a todas essas formas erráticas de expressão, a todos esses comportamentos “automáticos", enfim, em meio a esse Daniel “que não fala e que não para”, ele é também, na mesma medida, carinhoso. Daniel olha nos olhos, forte e intensamente. Gosta de contato físico e busca muito o rosto de outras pessoas, onde passa a mão. Basta que alguém tenha uma "cara boa" e "dê uma brecha" que ele abraça, mesmo sendo um desconhecido.

Nesses momentos privilegiados, Daniel chega a se envergonhar - como quando passeava comigo no parque e viu algumas crianças que lhe retribuíram o olhar. Diz de seus afetos e desafetos - como quando, ao levá-lo para casa depois de um passeio muito prazeroso, ao ver a avó vir abraçá-lo lhe virou as costas e segurou na minha mão com força. Tenta se sentir seguro - como certa vez, quando uma pessoa relativamente desconhecida dele veio cumprimentá-lo e ele alternava o olhar receoso para ela e depois para mim, como quem pergunta se está tudo bem.

\section{Acompanhamento}

A contrapartida das repetições dos modos de ser do Daniel é a constância (e repetição, também) de nossa presença e de nossas ações com e em relação a ele. De tal forma que se moveu uma ligação entre nós. Mas ele, por seu lado, permanece impossibilitado de dizer, com palavras, dessa ligação.

É assim que, por recorrências e repetições de nossa parte, se fizeram possíveis algo de novo e de mudança. O menino que não fala passou a dizer, sem palavras, um pouco de si: se utiliza de seu corpo como instrumento de ação sobre os outros (como comunicação, portanto). Aos poucos, à presença cativa desse psicólogo que, literalmente, o acompanhava em seu movimento constante, se fez seguir o primeiro gesto de comunicação de Daniel: pegar na minha mão e direcioná-la àquilo que ele deseja (à porta, 
ao doce, à geladeira, ao carro, etc.). Se Daniel corria, corríamos também, se ele andava, estávamos a seu lado, onde quer que fosse, no tempo em que estávamos com ele, poderia contar com a presença física e concreta de nosso corpo e de nossa atenção, invariavelmente à sua disposição, para a relação, a interação, a comunicação.

\section{Comunicação}

Essa comunicação por gestos ${ }^{28}$ - com o uso do corpo, de forma pouco discriminada e apoiada em elementos de necessidades sentidas (as "vontades" do Daniel) - é, como tudo neste capítulo, exemplar deste menino, no sentido de um corte em todas as repetições antes apresentadas. Acabou por se configurar também como uma recorrência: o uso do corpo como meio e suporte da comunicação.

Comunicação que é, para ele, um desafio constante, uma vez que parcial e opaca, limitada a um conjunto de reduzido de gestos e carente sempre de um contexto que lhe seja favorável, na atenção dispensada, na disponibilidade e no entendimento. Limitada também pelas possibilidades de uso do próprio corpo, pois Daniel parece não saber o que fazer, como fazer, com seus dedos, suas pernas, suas mãos, braços, cabeça.... Um corpo que parece sempre precisar de alguma escora para agir, um guia externo que indique como usá-lo para determinado fim. De tal modo que Daniel não reproduz modelos de posições do corpo (imitar) - uma mão fechada, mão espalmada, por exemplo -, mas é capaz de aprender posições simples se for "colocado" nelas, ou seja, se se fizer com seu corpo e no seu corpo o movimento. Um exemplo disso foi o aprendizado do gesto de "não" (balançar a cabeça): inicialmente, nos momentos em que imaginávamos que as ações dele

\footnotetext{
${ }^{28}$ Não se trata de Libras.
} 
significavam uma recusa, púnhamos a mão em seu rosto e o ajudávamos (fisicamente) a fazer o movimento. Algum sentido disso ressoou nele, de tal modo que em determinada ocasião, ele pegou minha mão, levou a seu rosto e balançou sua cabeça. Ele parece ter registrado não só seu gesto de não, mas toda a situação de aprendizagem, incluindo minhas ações. Hoje, ele faz por si próprio o gesto.

\section{Corpo}

De um lado, há seu corpo, de outro, seu movimento, entre um e outro Daniel se perde na impossibilidade de organizar seu movimento no corpo, ou seu corpo em movimento. Assim, ações simples, como abrir a embalagem de algum alimento, vestir-se ou ir ao banheiro, precisam constantemente desse "manual de como se faz", ao risco de ele não as realizar (o que é o pior) ou “dar seu jeito". Se for um alimento, por exemplo, é bastante provável que ele tente mordê-lo sem retirar a embalagem. Dessa forma, ensinar/aprender como fazer é mais uma das exemplares recorrências na vida do Daniel.

Encerramos por aqui esse capítulo, cujo objetivo foi o de apresentar o menino Daniel, que é tema e mote desta pesquisa, num quasi sem-tempo, uma vez que não abordamos as alterações, muitas, que já se seguiram a esse "quadro". Nos próximos capítulos, o compromisso de apresentar contextos, circunstâncias e relativizações está firmado, como preconiza a Ordem do Discurso (Foucault M. , 1971/1996) da instituiçãoPesquisa. E, além disso, prometemos voltar a alguns desses exemplos, com mais detalhes, no capítulo Corpo, movimento e sentidos. 


\title{
Capítulo 3.
}

\section{Uma Historiografia Diagnóstica}

\author{
Preâmbulo
}

Como a maioria dos pacientes com algum tipo de transtorno do desenvolvimento, Daniel tem uma vasta "experiência" em consultas médicas, exames, avaliações, laudos e tantos outros procedimentos que visam, em algum nível, a dizer sobre ele e suas dificuldades. Essa, ao menos, é a ideia corrente que se tem sobre a função destes dispositivos diagnósticos: retratar, definir, esquadrinhar, caracterizar, descrever e classificar uma realidade (sintomática, nesse caso). Há, no entanto, efeitos “impensados" e não intencionais desses dispositivos de produção discursiva. Nessa historiografia, trataremos destes últimos, o que será facultado por uma análise institucional dos discursos diagnósticos ${ }^{29}$ sobre Daniel e por considerarmos os discursos de especialistas da área de saúde como dispositivos de produção de saber (Foucault M. , 1976/1985; 1983/1995; 1979; 2006). Para fugir das dicotomias e deixar bem assentado esse recorte que fazemos, faz-se necessário mais algumas palavras.

\footnotetext{
${ }^{29} \mathrm{O}$ adjetivo caracteriza, em nosso caso, não apenas os discursos dos profissionais da medicina, mas os discursos da área da saúde de um modo geral, abarcando outros profissionais, instituições de tratamento/atendimento e outros dispositivos de avaliação.
} 
A dicotomia principal que queremos evitar é aquela entre os "bons" diagnósticos e os "maus" diagnósticos. Essa era a armadilha do Projeto $^{30}$ : pretender afinar o instrumento de avaliação, as lentes do microscópio, de modo a descobrir o que de fato afetaria o Daniel. Assim, o "bom" diagnóstico seria aquele mais preciso, mais certeiro e mais explicativo. O mau diagnóstico, acreditávamos, seria aquele que o Daniel tinha até o momento, um quadro demasiado geral e pouco preciso de autismo. Para além disso, o que está em jogo aqui é a insidiosa certeza de que seria possível afirmar uma verdade final e precisa para o quadro deste menino. Estaríamos no campo do verdadeiro, como diria Foucault (Foucault M. , A ordem do discurso, 1971/1996). Nesse campo, seria possível fazer diagnósticos, que seriam mais o menos corretos, verdadeiros, que poderiam ser refutados ou ratificados.

Para fugir dessa dicotomia, saímos um pouco deste campo do verdadeiro. Não vamos tratar diagnósticos no diapasão do certo/errado, os trataremos como discursos que, como tais, produzem efeitos de saber/poder e se produzem em relações de saber/poder (Foucault M. , 1976/1985; 1983/1995; 1979; 2006). Com isso, também não estamos dizendo que diagnósticos não deveriam ou não precisariam ser feitos. Não! Queremos apenas apontar para o fato de que o diagnóstico é o enlace discursivo final de uma história de avaliação e de produção de saber sobre uma criança. Em determinado momento, a história de Daniel e os dispositivos médicos/psiquiátricos encontraram-se e produziram um domínio discursivo ímpar. Esse domínio discursivo é o que responde pelo nome de "caso". Daniel tornou-se um caso; um caso de autismo, um caso de atraso no

\footnotetext{
${ }^{30}$ Como explicamos no Capítulo 1. Sobre este trabalho.
} 
desenvolvimento, um caso de atraso na linguagem, um caso de distúrbio neuromotor, etc. No "caso" se inserem a técnica e seus procedimentos, a descrição e observação (técnicas, também) do paciente, as ciências médicas, psicológicas e seus saberes, enfim, todo o discurso científico sobre uma patologia, também definida cientificamente, bem como os aparatos concretos ou virtuais utilizados para levar a cabo as avaliações e tratamentos, dos resultados de exames de sangue, de exames de imagem às ações e reações tecnicamente observadas e observáveis do paciente em testes psicológicos.

É ao desenho da história e dos efeitos desses dispositivos diagnósticos que nos referimos no título desse item sob o nome de historiografia. A historiografia será justamente o procedimento de recapitular, retomar e reconstruir a história dos pontos onde o "caso" e o Daniel misturam-se. Não propriamente a história do Daniel, mas a história diagnóstica do caso-Daniel. ${ }^{31}$

O material base para essa historiografia provém de duas fontes. A primeira, referente ao período de 2009 a 2013, constitui-se sobretudo de pedidos médicos e de resultados de exames solicitados, emitidos por diferentes profissionais. Esse material nos foi concedido pelos pais de Daniel, a pedido nosso, para consultar tudo que se tinha sobre

${ }^{31}$ Portanto, não vamos refutar diagnósticos, muito menos condená-los. São absolutamente necessários, sobretudo em condições tão atípicas como as do Daniel. Sua necessidade, no entanto, não implica que deixaremos de apontar seus efeitos nas malhas discursivas e nas relações institucionais que compõem os lugares desse menino. 
ele, em termos de exames e avaliações. No dia marcado, os pais nos entregaram uma sacola grande, um pouco velha, com tudo que diziam dispor. Dentre os documentos contidos nela, são raros os "laudos" ou mesmo algum tipo de fechamento diagnóstico. Salvo alguma exceção, este material é escasso, pouco conclusivo e opaco. Além disso, há lacunas que deixam a impressão de uma "tarefa inacabada"; por exemplo, há exames solicitados, mas não há o resultado desses exames (um deles genético, inclusive). É necessário frisar que nessa época (2009-2013) ainda não conhecíamos Daniel. No entanto, ele já era acompanhado (desde 2011) pela psicóloga Luisa, que foi quem nos apresentou a ele quando iniciamos seu acompanhamento.

A segunda fonte de materiais se refere ao período a partir de 2014. Esse foi o ano no qual iniciamos o atendimento do pequeno e, com isso, parte da historiografia foi construída em ato. Explicamos: a maioria das consultas médicas ou com outras especialidades contou com a minha presença (além dos pais), bem como o acompanhamento dos exames, resultados e devolutivas dos profissionais. Qualquer que fosse a instituição de saúde, o dispositivo, o procedimento, o discurso a que o Daniel estivesse sendo submetido, eu estava junto, muitas das vezes presencialmente, outras tantas acompanhando à distância, conversando com os profissionais, trocando relatórios ou mesmo colhendo informações com os pais poucas horas depois das consultas. Esses fatos tornam essa fonte radicalmente diferente da primeira, para o bem ou para o mal, eu pude construir uma versão dessa história, e por isso ela é escrita, aqui, de modo menos lacunar, menos "mal-acabada".

Um segundo efeito desse acompanhamento tão próximo é observado no próprio texto e no caminho que ele percorre. Como se verá, a partir do item $O$ mosaico, há uma radical mudança de registro discursivo. É como se não fosse mais apenas uma 
historiografia do caso-Daniel, mas já fosse uma parte da história do Daniel. Uma inversão, talvez, da própria ideia de diagnóstico... ${ }^{32}$

Vamos lá.

Primeira fonte de materiais: lacunas e certezas

Data de 2009 o primeiro exame de neuroimagem de Daniel. É uma tomografia computadorizada do crânio. Ele contava com um ano e cinco meses e havia caído da escada, segundo relato dos pais. Foi levado ao pronto socorro e, como procedimento de urgência, se realizou esse exame. Seu resultado foi de que não havia nenhuma alteração, além de um desvio de septo nasal. Nessa época, pelo que a história familiar narra, Daniel "não tinha nada", ou ao menos ninguém desconfiava ou parecesse notar qualquer característica “atípica” em seu desenvolvimento.

No primeiro semestre de 2010 o material de consulta tem sua primeira alteração: não mais receitas de antibióticos, prescrições de inalação, fichas de entrada em prontossocorros por conta de febre, nariz congestionado ou uma queda da escada. Começam a aparecer os médicos neurologistas e neuropediatras. É o período em que suspeitas a respeito do desenvolvimento do Daniel levam os pais a buscar parecer profissional. Os

\footnotetext{
${ }^{32}$ De modo análogo, mas partindo de um referencial conceitual diverso, diz Sacks, em referência à sua proposta de escritura: "Para devolver o sujeito humano ao centro [...] devemos aprofundar um relato de caso transformando-o em uma narrativa ou história; só então teremos um 'quem' além de um 'o quê"' (Sacks, O homem que confundiu sua mulher com um chapéu, 1997, p. 10)
} 
documentos que analisamos indicam uma investigação do quadro por partes destes profissionais.

Os pedidos iniciais de exames e solicitações foram feitos pela médica Carolina ${ }^{33}$. No alto de seu receituário está grafado "Neurologia-epilepsia". Ela solicitou: BERA, ressonância magnética, Eletroencefalograma, exames de sangue. Recomendou que o Daniel fizesse dez sessões de fisioterapia motora, por motivo de alteração na coordenação da marcha.

O BERA é uma avaliação audiométrica. Em casos que há suspeita de Trantorno do Espectro Autista (TEA) ele é solicitado para descartar a possibilidade de a criança não responder ao nome, ao chamado ou a sons de um modo geral por conta de um distúrbio auditivo. O BERA de Daniel não apresentou qualquer alteração ${ }^{34}$. Resultado: normal.

Outros elementos chamam atenção. Primeiro, o resultado do EEG: anormal, com discreta desorganização dos ritmos de base. Segundo, a solicitação/recomendação de sessões de fisioterapia motora, por conta de alteração de coordenação para marcha. Terceiro, que a família tenha procurado "de cara" uma neurologista. Por fim, o pedido do BERA, que, no rebote, indica a suspeita de autismo, mas os pais, provavelmente, não sabiam dessa suspeita.

Duas alterações (EEG e marcha), portanto, foram "detectadas" por meio dos procedimentos disparados pela médica Carolina. Mas, para por aí. A neurologista não

\footnotetext{
${ }^{33}$ Nome fictício.

${ }^{34}$ Sabe-se que o BERA é um exame que, quando realizado em crianças muito pequenas, há baixo índice de confiabilidade, uma vez que o sistema auditivo ainda está em maturação. Ou seja, o resultado do exame pode variar de acordo com a idade do indivíduo avaliado.
} 
reaparece com novos pedidos de exames ou qualquer outra solicitação. Ao que tudo indica, Daniel passou a se consultar com outro médico.

Sem se obter respostas sobre o que esse menino teria, as suspeitas aumentam, as incertezas também... Ao acompanhar esse material de consulta, o conjunto desses documentos produz um efeito de suspensão e angústia em quem se dispõe a, como nós, organizá-los. Parece que não vamos chegar a lugar nenhum, que não há um fluxo lógico que encadeie e enlace, com o mínimo de sentido, o médico, os exames e as intervenções. Se estivéssemos buscando respostas, mais fácil seria manter esses documentos arquivados e iniciar as pesquisas novamente. Em verdade, é isso que acontece na história desse caso, a cada médico consultado, a cada exame, a cada avaliação, a cada tratamento parece que se recria a cena de origem, como se Daniel não tivesse história, ou melhor, estivesse aquém dela. A descontinuidade e a suspensão são as marcas de sua história diagnóstica... Isto tanto no que eu pude acompanhar nesse périplo dos primeiros anos de trabalho com ele, como pela sequência do material que tentamos organizar dos anos anteriores. Voltemos.

O lugar de Carolina é tomado pelo médico Pedro, neuropediatra, no segundo semestre de 2010. Ele parece retomar a "investigação" do quadro. Note-se, no entanto, que a indicação de fisioterapia motora não aparecerá mais; Daniel não fez as sessões, ninguém explica porque foi indicada essa intervenção e o "assunto morre", na mesma velocidade e no mesmo ato de seu aparecimento, como palavras grafadas em água.

Pedro solicita (mais) uma ressonância magnética e, aí está a novidade de sua entrada, alguns exames genéticos. Ele encaminha seus pedidos com a marca "HD" (hipótese diagnóstica). E quais são essas HDs? Síndrome de Sotos e X-Frágil. O resultado deste último é negativo, a HD não se confirma. Para Sotos, parece não ter sido realizado 
exame específico. Não há o resultado. É como se investigação se estancasse no levantamento da hipótese. Mais uma dessas efêmeras marcas.

Há, no entanto, mais um detalhe, de Carolina a Pedro manteve-se a busca diagnóstica, mas perdeu-se a intervenção. Esse é um fato curioso dessa história: um desenlace, certo desencontro, entre diagnóstico e intervenção. A pergunta “O que o Daniel tem?" existe e se faz presente, no avesso, justa e simplesmente por haver esses documentos. Já a pergunta “O que fazer com o Daniel?" é obscurecida, esquecida...; simplesmente ela não existe, e o discurso que a materializa se perde numa indicação fisioterápica apagada na memória e no tempo.

O exame genético solicitado por Pedro foi um cariótipo de bandeamento. Resultado: normal ${ }^{35}$.

$\mathrm{Na}$ linha das hipóteses diagnósticas, Pedro solicitou uma avaliação neuropsicológica. Em sua guia grafou "HD: TGD” (hipótese diagnóstica: transtorno global do desenvolvimento, um outro nome para autismo).

O relatório da neuropsicóloga é a primeira avaliação mais completa de Daniel, nela são descritos seus comportamentos e modos de agir. É também a mais insidiosa. Explicamos: neuropsicólogos, em geral, aplicam testes e avaliações. Sabemos, que esses dispositivos são validados para serem usados na exata medida do que seu escopo faculta. Assim, testes de inteligência "medem" inteligência (seja lá o que isso for); testes

\footnotetext{
${ }^{35}$ Muito embora, para certas síndromes há chances consideráveis de o cariótipo dar um falso negativo por ser um exame "genérico" demais. É o caso da Síndrome do X-Frágil (Dew-Hughes (org.), 2004) . Com isso, infelizmente, perdeu-se, ainda sem vislumbre de retomada, a oportunidade de uma discriminação sindrômica mais específica do quadro de Daniel.
} 
projetivos "configuram" perfis emocionais e de personalidade, na maioria das vezes; testes de processamento linguístico avaliam... processamento linguístico; e assim por diante. O "teste" aplicado para avaliar o Daniel foi a escala de comportamento adaptativo de Vineland, que "mede" o comportamento adaptativo, ou seja, se o sujeito avaliado corresponde ou não, e o "quanto" corresponde ou não, ao grau, quantidade e forma de comportamentos adaptativos esperados para sua idade de referência. Mas o resultado dessa avaliação, apresentado no relatório, é o de que Daniel teria um quadro compatível com autismo. Ora, a escala Vineland não foi criada, nem validada, para avaliação diagnóstica de autismo ou qualquer outro transtorno ou síndrome. O resultado apresentado pela neuropsicóloga é incompatível com o instrumento da avaliação usado. A escala Vineland "mede" o nível funcional, adaptativo, da criança em diferentes aspectos, como dissemos. Mas não discrimina um quadro diagnóstico, qualquer que seja. Uma vez que alterações no "nível funcional" (sobretudo rebaixamento) é uma característica que atravessa número incontável de transtornos e síndromes.

Ainda nesse ano de 2010, há outro relatório. Desta vez de uma fonoaudióloga, que faz apontamentos sobre o trabalho e as produções verbais de Daniel em sessões. Segundo os pais, em 2010 Daniel iniciou psicoterapia e fonoterapia.

Curiosamente, a partir de 2011, e nos anos seguintes, o material esgarça-se. Um ou outro pedido médico, um ou outro exame. Nenhum diagnóstico ou laudo. O último pedido de exame de Pedro é desse ano, um EEG, cujo resultado foi "sem anormalidades". E esse médico desaparece dessa história. Ao que tudo indica, ele acompanhou Daniel em duas consultas num intervalo de um ano, levantou as HDs acima descritas, mas não emitiu laudo definitivo nem indicação de tratamento em forma de documento. Segundo os pais, ele teria afirmado em consulta que Daniel teria autismo. E só... 
Há mais alguns apontamentos importantes a serem feitos sobre esse período, agora, no contexto escolar. É precisamente neste ano de 2011 que Daniel é matriculado na escola Vivência $^{36}$, e algumas falas que circularam à época são especialmente relevantes para esta historiografia, as quais tivemos acesso por meio de relato de Luisa Guirado ${ }^{37}$.

Entre o final de 2010 e início de 2011, a diretora da escola contatou Luisa, então psicóloga recém-formada, dizendo que receberia para o ano letivo de 2011 uma criança, de três anos, com "características de autismo", e que ela provavelmente necessitaria de um acompanhamento terapêutico (AT) na escola, convidando-a assim a realizar esse trabalho, caso de fato fosse necessário. No início do ano letivo, passados alguns dias de aula, é confirmado o convite e Luisa assume o AT dessa criança, o Daniel. Além da conversa com a diretora, ao assumir o AT, Luisa marca uma reunião com os pais de Daniel, que é realizada na escola, contando com a presença apenas do pai. Nessa reunião, ele afirma que "Daniel tem autismo" e, quando perguntado sobre quem teria emitido o diagnóstico e porquê, diz que fora o médico Pedro, por conta do resultado do $\mathrm{EEG}^{38}$.

Daniel teria chegado a essa escola por questões relativas às facilidades de locomoção: era uma instituição próxima ao trabalho dos pais. Ele permanecia nela o período integral, os pais o deixavam antes de ir para o trabalho e o pegavam ao final do turno. Luisa, por sua vez, teria chegado a essa escola por questões relativas ao "autismo de Daniel", ao que tudo indica, uma marca que já se acoplara a seu nome. Ela o

\footnotetext{
${ }^{36}$ Nome fictício.

${ }^{37}$ Luisa Guirado é psicóloga (PUC-SP), Mestre e Doutoranda na área de Desenvolvimento Humano e Saúde do Instituto de Psicologia da Universidade de São Paulo (USP), escreveu A direção do olhar nos tratamentos do autismo (Guirado \& Guirado, 2014/2018). É fundadora da Equipe Novo Olhar (http://www.equipenovoolhar.org/).

${ }^{38}$ Esse, provavelmente, foi o registro e entendimento possível que o pai pôde ter à época. )
} 
acompanhava diariamente, apenas meio período. Esse modelo se estendeu até o final de 2012, dois anos portanto, até que Daniel saiu da escola Vivência ${ }^{39}$.

Ainda em 2011, há algumas guias assinadas por um novo médico, Saulo, um nutrólogo/alergista. Guias deste médico reaparecem no ano de 2013.

Curiosamente, é esse, e apenas esse, o material de que dispomos para essa historiografia até o ano de 2013. Mais curiosamente ainda, em 2012 não há nenhum registro de exames, pedidos, receitas ou indicações médicas. O material, portanto, diz mais pelo que falta do que pelo que se afirma. Retomemos o conjunto dos documentos:

- As especialidades médicas são sempre "Neuro";

- Dois EEG solicitados, o primeiro com resultado anormal e o segundo com resultado "sem anormalidades";

- Indicação de fisioterapia motora por conta de alteração na marcha (nunca realizada);

- Diversas HDs, inclusive de quadros genéticos (síndromes);

- Exames (BERA) e HDs (TGD) que no rebote falam de autismo;

- Uma avaliação neuropsicológica;

- A escola que solicita uma AT para uma criança com "características de autismo".

\footnotetext{
${ }^{39}$ Os fatos relativos ao período de acompanhamento de Luisa, que incluem o trabalho na escola Vivência,
} serão tratados mais à frente neste trabalho. 
Há nesse material curiosas repetições e estranhas lacunas. As repetições são as das especialidades médicas; todas têm o prefixo "neuro" acoplado. Neuropediatra, neuropsicóloga, neurologista (não consideramos o nutrólogo nem a fonoterapeuta pois não aparecem no exercício do diagnóstico, mas já como tratamento). Assim, o primeiro recorte dos profissionais já define, em termos gerais, um lugar para Daniel: ele é o caso de um menino que tem um problema nos nervos, no cérebro, na "cabeça".

Que tipo de problema? O que ele tem? É aqui que o silêncio das lacunas dos documentos médico-diagnósticos estranhamente ressoa. Nenhuma avaliação é discriminativa, há apenas alusões. Desde os testes genéticos, normal e inconclusivo ao mesmo tempo, até a insidiosa avaliação neuropsicológica, bem como a ressonância e os EEGs; não há definição. É como se as pesquisas diagnósticas iniciais, todas aquelas HDs, estivessem em suspensão, arquivadas em alguma gaveta. Isso implica que, do ponto de vista formal da medicina, Daniel não tem, até esse momento, nenhum diagnóstico.

Entre as lacunas e repetições, há uma certeza se construindo sobre esse garoto: ele tem uma doença, um transtorno, um distúrbio da/na cabeça, do/no cérebro. Lacunas e repetições fazem um binômio cujos efeitos discursivos concretos são potentes marcas dessa história.

O que estamos buscando destacar se resume da seguinte forma: não há conclusão nem continuidade nessa história diagnóstica. E isso é o mais importante. Há, sim, uma suspensão, um congelamento, tudo fica "no ar". Pois as suspeitas e as iniciativas que dispararam o conjunto de procedimentos médicos permaneceram tão somente como iniciativas e suspeitas nesses dispositivos "oficiais".

Suspeitas suspensas que, no rebote, produzem certezas nos discursos “extraoficiais", sobretudo aquele veiculado pela família e pela escola. Isso porque, 
embora haja essas lacunas na história diagnóstica, Daniel continuou fazendo história em outros contextos e ambientes em que era apresentado como "um menino com autismo", "um menino com características de autismo". Desde a primeira HD e o insidioso relatório neuropsicológico, Daniel tornou-se, extraoficialmente, mas de fato, um caso de autismo.

Dispositivos discursivos, em domínios de saber diferentes, alinharam-se e alimentaram-se mutuamente, sem que isso fosse orquestrado "de fora", por uma cabeça ou grupo pensante. O diagnóstico de autismo de Daniel foi configurado no exercício de forças entre as lacunas de uma história de pesquisa diagnóstica e o discurso familiar e escolar sobre esse menino. É curioso, nesse sentido, que o autismo aparece com materialidade contundente nas falas, não nos documentos. Por isso as lacunas e suspensões não são faltas ou buracos nessa história, são ocasião de positivação do discurso sobre o autismo de Daniel, pois são apropriadas e preenchidas ora pelo discurso familiar, ora pelo discurso escolar. Sendo que a escola cumpriu um duplo papel: aceitou Daniel como seu aluno, mas mais que isso como seu aluno com autismo. Legitimou-se, assim, no cruzamento de três instituições - a família, a escola e a da saúde mental - a marca: "Daniel, um menino que tem autismo". Esse tornou-se seu lugar enunciativo de partida, onde quer que fosse, onde quer que produzisse história, Daniel seria sempre acompanhado do discurso do autismo.

Com tudo isso, os documentos contidos na sacola "diagnóstica" não acusam um enlaçamento de estratégias de intervenção. Estas se desenvolvem num a parte, apagandose nas malhas desses registros, e sua história é independente de documentos. A diretora da escola diz que Daniel precisa de acompanhamento terapêutico, os pais dizem que ele faz psicoterapia e fonoaudiologia... Curiosamente, as intervenções, como o diagnóstico de autismo, constituem-se num domínio discursivo de transmissão oral, arriscam-se a 
sofrer as vicissitudes do esquecimento e dos desencontros de registros. Mas, não são nada efêmeras, essas verdades assim produzidas.

Como um menino que tem autismo, Daniel nos é apresentado quando iniciamos seu acompanhamento. Portanto, para todos os efeitos, e por todos esses efeitos, como um caso de autismo.

É assim que, em 2014, iniciamos o acompanhamento terapêutico de Daniel, por indicação da psicóloga Luisa. Quando, ainda em 2013, Daniel saiu da escola Vivência, a família mudou-se da zona sul para a zona leste da cidade, dificultando muito a regularidade do acompanhamento de Luisa, que não obstante, manteve contato com ele no primeiro semestre deste ano (apenas uma vez por semana, por algumas horas). Além disso, Daniel não frequentou a escola até a metade de 2013, sendo matriculado apenas no segundo semestre, em um colégio daquela região. No final deste ano, os pais de Daniel retomaram o contato com Luisa, solicitando a volta dos atendimentos do pequeno; ao que se sabe, por uma demanda que ia da escola nova (que dizia "não saber o que fazer com o Daniel") a seu pai que avaliava que Daniel não estava sendo estimulado adequadamente. Dessa forma, em 2014 Luisa voltou a atendê-lo, agora em consultório, e eu passei a acompanhá-lo na escola, por indicação dela.

Segunda fonte de materiais: outros caminhos do diagnóstico

Já acompanhávamos Daniel, portanto, quando, em mais uma virada nessa história, ele começou também a ser atendido em um programa do Governo Estadual para crianças 
com TEA em que seus pais lhe conseguiram uma vaga. Muda-se, em relação a primeira parte dessa historiografia, a qualidade técnica do nome: de autismo para Transtorno do Espectro Autista. Será que, por fim, o caso oficializou-se? Não mais como uma história cuja legitimidade vem de uma narrativa (des)lembrada, mas uma legitimidade produzida no bojo dos dispositivos médicos de produção diagnóstica?

Muda-se também o regime discursivo, como num salto, passamos dos discursos diagnósticos para os de intervenção. No entremeio, mas elidido, o quadro "extraoficial" de autismo.

Foi a médica responsável por essa instituição a primeira profissional a emitir um laudo definitivo. Segundo o que ela escreveu: "Daniel tem quadro compatível com TEA"; e acrescentou os números dos manuais de referência "F.084 e CID 10".

Uma observação curiosa: esse documento é emitido pelo menos seis meses depois de Daniel se tornar parte da clientela dessa instituição e frequentar regularmente seu programa de terapias. Emitido por pressão dos pais. Estes, por sua vez, pressionados pela escola que, dizia, precisar do "laudo" para justificar perante o Ministério da Educação as aprovações automáticas do menino.

Nesse tipo de instituição (que atendem especificamente crianças com TEA), a caracterização da clientela é critério de seleção para a "entrada" no circuito institucional. Lembremos que se trata de um serviço público especializado, muito demandado na cidade de São Paulo, e, mesmo assim, nosso pequeno (por seus belos olhos?) adentra seu circuito e participa de suas rotinas estando, no mesmo ato, à margem dele, uma vez que quando de sua entrada não tinha qualquer laudo "oficial". Assim, ao que parece, o diagnóstico não foi para ele critério de seleção, mesmo assim passou a ser atendido regularmente como uma criança com TEA. Diagnóstico esse que foi emitido seis meses depois, como 
se viu, num jogo que envolve exercícios de lugar e relações de poder entre três instituições: a médica, a familiar e a escolar.

Como se pode ver, diagnóstico emitido, embora legítimo, produz-se no encontro e no embate de instituições diversas, por exercícios que transpassam o da esfera rigorosamente médica e científica. Nesse plano discursivo em que tratamos a questão, o das relações poder-saber, é possível dizer que Daniel tem um quadro de TEA (ou autismo) porque é atendido em uma instituição para autistas, porque é aprovado automaticamente pela escola, porque a família tem um filho com autismo. Grandes metonímias, todas essas.

Observe o leitor que não se questiona, de nossa parte, se Daniel "tem" ou não determinado diagnóstico, no caso, o de autismo. Aponta-se, isso sim, para os efeitos dos procedimentos e dispositivos (oficiais ou não) pelos quais Daniel passou a ser reconhecido como um "menino autista". Procedimentos e dispositivos que se constituíam apartados da materialidade discursiva do corpo e da ação deste menino, que não obstante lhe submeteram a classificações, nomes e lhe conferiram sintomas e características nosográficas.

Como dissemos acima, essa segunda fonte de dados é colhida em ato. O que se relatou e analisou há pouco foi feito quase que testemunhalmente. Nessa época, já atendíamos Daniel e acompanhamos sua entrada na instituição referida, bem como em todos os outros procedimentos e dispositivos a que foi submetido. Inclusive, muitos deles solicitados por nós, como psicólogos e terapeutas do pequeno. Fazíamos, inegavelmente, parte destes dispositivos médicos. Por isso, essa escritura pode ser um pouco confusa, uma vez que há dois lugares em embate, o psicólogo daquela ocasião e o "historiador" de 
agora. Que o leitor tolere, por um tempo, essa duplicidade ao falarmos de o que o psicólogo do Daniel (nós mesmos) fez e pensou àquela época.

Desse lugar institucional, apontávamos e caracterizávamos o comportamento geral dele e, curiosamente, dávamos destaque mais a seu corpo, por assim dizer, do que para a sua "cabeça"; para todas as suas formas de expressão e ação, formas que são erráticas, intensas e obscuras na maior parte do tempo. O que configuramos sobre o Daniel, também por meio dos dispositivos e discursos de nossa ação profissional, se nos apresentava assim:

- Como um quadro perene de "agitação", um movimento constante, incessável. Daniel não para.

- Como uma ausência total de fala ou qualquer outra forma de comunicação (incluindo aqui gestos, olhares, uso do corpo, apontar, etc.). Nada, absolutamente, dava notícia de si.

- Como uma intensidade e força no movimento, uma rigidez muscular, sobretudo nas mãos, braços, costas e pescoço.

- Como, apesar de todas suas dificuldades, é capaz de ser amoroso e carinhoso; intensamente também, é verdade.

Se foi notada certa suspensão do quadro de autismo, não foi à toa. Pelo contrário. Foi de caso pensado.

O primeiro contato com o Daniel, no plano de seu efeito sobre nós, foi de um irrefreável estranhamento, que pode ser descrito como um descompasso entre a expectativa (imaginada) e a situação concreta de contato com ele. No plano da 
expectativa, carreava-se para o acompanhamento aquilo que sabíamos sobre crianças com TEA (teórica, clínica e experiencialmente), bem como a narrativa familiar sobre ele. No contato concreto, no entanto, o que saltava a nossa observação, era, antes, o movimento intenso e sem freio desse menino, que disparava em corridas pelos pátios da escola, que girava cadeiras quase de seu tamanho, que se direcionava para as janelas e batia suas mãos, calejadas pela repetição desse gesto, nos batentes, que levava o que quer que fosse à boca; e com tudo isso, um menino que não media forças nos carinhos e abraços que distribuía àquelas que, na escola, lhe ofereciam o corpo e a intenção no mesmo gesto, que olhava profundamente, sem receio, nos olhos. Além disso, um menino cujo movimento parecia dessintonizado do contato com o mundo, mas a intenção não; como um rádio que capta e perde a frequência da estação, Daniel procurava o que desejava, mas sem meios de levar a cabo tal ideação, perdia-se em ruídos. Assim, pegava seu iogurte, mas ao invés de abri-lo ou se dirigir a quem pudesse fazê-lo, ele mordia a embalagem, batia na tampa, girava-o.

Daniel não era ou estava alheio ao mundo, ao que nos parecia. Em verdade, encontrava-se incapacitado para atingi-lo por meio de sua ação. São coisas diferentes, e o que importa não é o nome que daremos a isso ou como se classificaria, mas a descrição desses desemparelhamentos concretos do discurso-ato do Daniel ${ }^{40}$. Retomou-se, aqui, às raias da consciência, o âmbito da intervenção, aquele "o que fazer" que, desde a primeira consulta médica com indicação de fisioterapia, se perdeu/esqueceu em favor do diagnóstico.

${ }^{40}$ Ver Michel Foucault sobre a ideia de discurso-ato (Foucault M. , A ordem do discurso, 1971/1996). 
Nesse ato de suspensão dos saberes sobre o autismo e o autismo do Daniel, mais um exercício concreto da ação profissional se fez presente, que pode ser representado por uma pergunta: "Como as pessoas o veem? Como circunscrevem suas dificuldades e como lidam/reagem a elas?’41. Dissemos que Daniel era atendido num Serviço público; lá ele contava com fonoterapia, psicoteria e integração sensorial, bem como com acompanhamento psiquiátrico. O primeiro passo, então, foi agendar reuniões com os profissionais. Na primeira delas, com a presença da coordenadora do projeto, foi exercido o primeiro corte: a instituição indicou que Daniel suspendesse a psicoterapia com a psicóloga Luisa Guirado, justificando que isso influenciaria as intervenções realizadas no Programa (em linguagem da instituição, seria uma variável incontrolável); manteve-se, no entanto, o acompanhamento que eu realizava na escola, por motivos óbvios que dizem respeito às dificuldades do Daniel e do despreparo da instituição de ensino. Esse foi um movimento característico de instituições de cuidado global, cerceando o domínio sobre seu objeto institucional (o atendimento à clientela) e excluindo outros dispositivos que ameaçam esse domínio. Não houve o que fazer... Os pais concordaram e a psicoterapia com Luisa foi interrompida.

Outras reuniões foram marcadas e realizadas, com o objetivo de "discutir o caso" e "alinhar as estratégias". No entanto, o único participante que se repetia em todas elas era eu, isso porque o quadro dos profissionais técnicos do Serviço alterava-se

\footnotetext{
${ }^{41}$ De certa forma, essas perguntas já instrumentavam o atendimento de Luisa (2011-2013), embora os discursos diagnósticos e da escola, à época, fossem mais insistentes.
} 
frequentemente, e num intervalo de um ano Daniel já tinha "passado" por três diferentes fonos e psicólogas naquela instituição. Assim, as reuniões eram, quase sempre, de apresentação, de reinicio, em cada uma delas traçavam-se estratégias que, na reunião seguinte, não poderiam ser avaliadas em seus efeitos, pois os profissionais já não eram os mesmos e, curiosamente, não tinham, em nenhum registro oficial da instituição, o histórico das intervenções e metas acordadas entre nós e os anteriores. Esse é o segundo corte, que, na chancela de uma instituição, acaba por repetir a descontinuidade do e no caso-história-Daniel. Assumíamos nessas ocasiões, por exercício de nosso lugar, a posição de porta-vozes dessa história, pelo uso de instrumentos facultados aos psicólogos: os relatórios de acompanhamento, assinados e carimbados.

De certa forma, é esse o lugar discursivo que confere uma radical diferença à segunda parte dessa historiografia: é o lugar de organizador. Como uma narrativa que agrupa e reapresenta registros discursivos sobre um mesmo garoto, evitando a dispersam e a perda dessa história. Um organizador externo que é como uma narrativa da história de Daniel (em qualquer de suas ordens), é esse lugar que, por um conjunto de circunstâncias, nosso acompanhamento terapêutico exerceu nesse momento.

Um dos temas das reuniões eram as características sui generis da ação do Daniel: intensas, fortes, descoordenadas, descontextualizadas... $\mathrm{Na}$ reunião em que isso foi discutido, estava presente, por nossa solicitação, felizmente, a coordenadora do Programa (uma das únicas profissionais constantes na instituição, mas que por sua posição hierárquica não participava do miúdo das intervenções), que endossou a hipótese de uma comorbidade de ordem neurológica (especificamente, motora) e solicitou um EEG. Em seu resultado grafava-se o termo anormal, seguido de explicação: ondas epileptiformes. 
Em decorrência, por meio da equipe médica do Programa, foi ministrado Ácido Valpróico a Daniel, com efeitos visivelmente benéficos em seu estado geral.

$\mathrm{O}$ efeito desse acontecimento marca irremediavelmente a continuação dessa historiografia. O endosso da coordenadora (médica), o EEG e o efeito da medicação foram disparadores de procedimentos e dispositivos que visavam a dar um contorno mais específico e individualizado para o quadro do Daniel. Dispararam, por assim dizer, uma nosografia particular, singular, do caso. Inverteram-se os vetores de atenção: não mais o geral “O que o Daniel tem?”, que só podia ser respondido com uma afirmação também geral e inespecífica “Daniel tem o Transtorno ou a Síndrome X”, mas “Como é o Daniel?". Nesse como é implicava-se os modos como Daniel pensa, age, interage com o mundo, processa informações sensoriais, lembra, etc. Sobre isso, claro, tudo que se poderia produzir seria, provavelmente, hipotético; entretanto, o que estava no foco da atenção, agora, era um pouco mais próximo do Daniel e de seu discurso concreto, muito além de um caso de autismo.

Em meio a essa mudança de foco, reunimo-nos com os pais de Daniel (mais uma das ocasiões de exercício do lugar de organizador desse acompanhamento). Nessa ocasião tivemos a oportunidade de levá-los, como nós, a suspender as certezas sobre o autismo e principalmente o autismo do Daniel. Dois argumentos formaram a base da conversa: $a$. a anormalidade flagrada no último EEG não poderia ser desconsiderada, particularmente porque indicava uma atividade epileptiforme na região temporal do cérebro. Dois elementos preocupavam, a referência à epilepsia (por motivos já conhecidos da medicina, o petit mal é um distúrbio neurológico com riscos agudos à vida, mas que pode ser controlado com medicação específica, além do fato de haver uma frequência alta de comorbidade da epilepsia em casos de autismo, como Daniel era 
classificado até o momento) e à região do córtex cerebral, pois o lobo temporal (esquerdo) é responsável pela fala e linguagem (e como sabemos, Daniel não falava, sequer se comunicava de outras formas $)^{42}$. $b$. Há, na literatura especializada, diversos relatos de síndromes cuja sintomatologia é similar à do transtorno do espectro autista, muito embora sejam quadros diversos, com evoluções distintas e peculiaridades que podem modificar os caminhos de intervenção (inclusive medicamentoso), dentre elas podem-se citar a Síndrome do X frágil (Dew-Hughes (org.), 2004), Síndrome de Rett (para mulheres, o que não é o caso presente), Landau-Klefner (ou afasia infantil) (Pearl, Carrazana, \& Holmes, 2001).

Nessa reunião, chegou-se ao consenso de que seria imprescindível que Daniel fosse a um neurologista, o quanto antes. Mas, diferentemente dos médicos anteriores, a esse não seria dirigida a pergunta “O que ele tem?”, cuja resposta poderia ser “Autismo, o que mais?!". Perguntaríamos sobre o que mais, além de autismo, o médico poderia nos dizer sobre o Daniel e seus sintomas à luz dos argumentos apresentados acima.

Nesse contexto, agendou-se uma consulta com o neuropediatra Mario, na qual estávamos presentes, acompanhando o Daniel e sua mãe. Iniciou-se a conversa como previsto, “o que mais é possível dizer sobre ele?”. E ela seguiu ao longo de hora e meia, que contamos com a imensa paciência e bom humor do pequeno, tolerando o tempo de reclusão e mostrando-se ao médico em sua melhor forma: muito agitado, mas feliz e carinhoso. Mario fez uma longa e detalhada anamnese, perguntou sobre a evolução do

\footnotetext{
42 Ver anexo sobre Luria, onde tratamos de hipóteses neuropsicológicas a respeito alguns "sintomas"
} práxicos de Daniel. 
Daniel e fez as avalições físicas de costume (reflexos de tendões, observação de marcha, medição de cabeça, etc.). Por fim, disse-nos o que depois escreveria em carta, como segue:

Paciente com quadro de atraso global DNPM, deficiência intelectual moderada, agitação psicomotora, movimentos involuntários (tiques, estereotipias complexas), com dificuldade na interação social, repertório restrito de atividade compatível com transtorno do espectro autista.

Sugiro:

- Manter abordagem comportamental, com ênfase em regulação sensorial e [ilegível]

- Avaliação genética (O quadro de deficiência intelectual moderada é central e há características fenotípicas e a expressão das estereotipias é mais brusca e desorganizada)

- Sugiro manter Ácido Valpróico.

Coloco-me à disposição para esclarecimento

$11 / 03 / 2016$

Essa carta e essa consulta médica subvertem o sentido da história dos diagnósticos (médicos) de Daniel. Isso porque quebra a regularidade das lacunas que vimos acompanhando até então, na primeira parte, onde hipóteses eram levantadas, mas não confirmadas nem refutadas, onde avaliações eram realizadas e termos cunhados em situações cujas forças em jogo extrapolavam o âmbito estrito da saúde e dos dispositivos “oficiais" de avaliação e intervenção. A título de lembrança, uma escala psicométrica 
usada como se fosse diagnóstica e, ainda, a escola pressionando por laudo oficial, qualquer que fosse. Como se vê, a produção de verdades se dá, sempre, em e por relações de poder.

O que muda, então, nesse momento? Muda-se o discurso, seu movimento e as relações de poder/saber que enseja. Vejamos como.

O primeiro apontamento é da ordem das palavras usadas pelo médico, algumas novas, outras já esquecidas. A novidade está nos termos: atraso global DNPM (desenvolvimento Neuropsicomotor), deficiência intelectual, movimentos involuntários, agitação psicomotora, regulação sensorial. Além disso, a carta retoma e reapresenta um termo esquecido na história médica deste menino: "motor". A primeira neurologista (Carolina) havia indicado, como vimos, fisioterapia motora para ele. Eis que seis anos depois, o termo reaparece em algumas das construções deste documento. O segundo apontamento é sobre o lugar do autismo, que não é colocado como o quadro central, embora tampouco se o descarte. Bem se vê, em verdade, que não há propriamente um diagnóstico nessa carta, antes a descrição de sintomas do ponto de vista e a partir dos dispositivos e saberes da neurologia.

Esse documento é assim uma peça que dá nome e existência a elementos dispersos da sintomatologia de Daniel que, até então, estavam à margem de seu quadro tal como considerado medicamente. O "atraso global DNPM" (atraso do desenvolvimento neuropsicomotor) é seu ponto central, uma vez que sintetiza um conjunto amplo, mas diacrítico, de elementos. Neuro, psico, motor e sensorial abrem o discurso médico para uma outra direção; mais descritiva e abrangente, porém discriminadora de caminhos.

Na sequência, Daniel foi à consulta com a psiquiatra Denise. O sintoma alvo de sua intervenção, segundo informou, seria a "agitação psicomotora". E o tratamento 
farmacológico foi realizado com Aripiprazol® ; mantendo-se Depakene®. Na consulta, Daniel estava em seu "estado padrão", ou seja, com ótimo humor e constantemente em movimento. A sala de Denise tinha em torno de $15 \mathrm{~m}^{2}$, não era pequena, não era grande, mas ele a fazia parecer minúscula, ora deitava no sofá, ora abraça a mim ou à mãe, ora girava-se na cadeira, ora pegava uma almofada que largava ao chão, ora um brinquedo e fazia o mesmo, ora corria e batia as mãos na parede, ora apanhava as canetas da mesa, logo as derrubava.... em termos médico-psiquiátricos: agitação psicomotora.

Essas duas consultas médicas compõem com nossa avaliação e aposta iniciais: algo de ordem motora, sensorial, "corporal" estaria desregulado de alguma forma. Essas duas consultas dispararam algumas avaliações com outros profissionais. Na sequência, as apresentaremos, como fotos tiradas (quadros) por um viajante que as armazena na bolsa. Ao final, tentaremos montar um painel (mosaico) com essas fotos.

Quadro 1: Piaget e cognição (Professor Lino de Macedo)

Consultamos por duas vezes, na qualidade de profissionais, o pesquisador e Professor Titular da Universidade de São Paulo, Lino de Macedo, que trabalha com desenvolvimento infantil para supervisão de nosso atendimento e avaliação de Daniel. Na primeira reunião fizemos um relato geral sobre o pequeno e seu atendimento, as maiores dificuldades, os modos como ele age normalmente, o que nos chama atenção e aquilo que é marcante em seu comportamento geral. Apresentamos-lhe também alguns vídeos de Daniel na escola, realizando atividades propostas ou interagindo com objetos do 
ambiente. Na segunda vez, levamos Daniel para conhecê-lo, de modo que o Professor Lino de Macedo pudesse observá-lo, observar nossa interação, bem como interagir com ele. Depois desse encontro, marcamos outra reunião.

$\mathrm{Na}$ sequência, apresentaremos as observações, opiniões e apontamentos do Professor sobre Daniel. Gostaríamos de abrir essa apresentação com duas falas dele, que já adiantam o tom da prosa...

"Cognitivo é relativo ao conhecimento... Mas ao conhecimento do quê?! Ora, de tudo que se trata de conhecer. O corpo, o mundo, o simbólico..."

"Quanto mais comprometimentos a criança tiver, mais deveríamos pagar para atendê-la. A gente aprende muito com elas. E elas colocam em xeque nossos limites." ${ }^{43}$

Segundo o Professor, dois motores fundamentais que impulsionam a criança do estágio da inteligência sensório-motora para o da inteligência simbólica são a marcha (o andar) e a fala, que permitem uma organização de outra ordem do tipo de experiência com e no ambiente por meio do uso do corpo e da ação. Elementos esses que estão alterados, defasados ou ausentes para o Daniel. De tal forma que, é bem possível, que seja necessário ainda "malhar" bastante as experiências sensório-motoras com ele, uma vez que estas seriam a base para a formação de imagens (representações).

Segundo sua avaliação, Daniel teria um estilo "touch", ou seja, ele toca em tudo e bate com suas mãos nos objetos, na mobília, nas paredes e batentes. Um comportamento

${ }^{43}$ Comunicação pessoal em 12 de abril de 2016. 
que, no entanto, não é destrutivo nem completamente descoordenado. Mesmo nesse bater e tocar, Daniel tem algo que é preservador do ambiente.

O toque é a principal forma de comunicação da criança no sensório-motor... O mais importante para ela, nessa fase, é tocar e ser tocada. Com a passagem do tempo, ao longo do desenvolvimento, a criança passa a "tocar" pelo olhar e pelo falar. Mas Daniel ainda toca pelo touch, pelo toque real e concreto.

Seu toque, no entanto, tem algo que é escolhido, um ritmo, um toque que parece que tem um sentido, um critério. Para o Professor, o toque e o bater de mãos do Daniel são formas de expressão. Algo, ainda que de longe, análogo à tagarelice do adulto.

Sobre o início do desenvolvimento da fala, Lino de Macedo destaca que o primeiro estágio da fala é... ouvir. A fala supõe um adulto falante, falante para a criança e falante sobre a criança. É assim que, no segundo estágio, em decorrência das experiências de ouvir falar de si, sobre si e para si, a criança se "sente" disponível para emitir sons e articulá-los em palavras, o que começa com uma imitação de palavras, e palavras que têm uma base empírica, concreta, bem clara.

Assim, no desenvolvimento, a criança integra o mundo sensorial-motor num mundo, digamos, mais evoluído, simbólico. Mas o Daniel parece ter substituído... substituído a fala pelo touch. De tal forma que seu mundo torna-se regido pelas formas das experiências sensório-motoras. No nível cerebral, é como se o sistema autônomo (musculatura lisa, homeostase, etc.) gerisse o comportamento e ação do Daniel, de forma que a intencionalidade possível de seu gesto é a que esse sistema lhe permite ter: a autorregulação. 
Por essas observações, o Professor faz algumas sugestões - igualmente importantes, na medida que também dão mais pistas sobre o pequeno - para o trabalho e a relação com o Daniel. Ou seja, ele faz derivações concretas para a vida do pequeno.

- Falar para o Daniel, sobre o Daniel, com o Daniel. Ele deve se ouvir pela voz de um adulto falante.

- Obter a cooperação dele, por meio de práticas lúdicas e prazerosas. Coação e sedução não são estratégias que funcionem em casos-limite como o dele.

- Estar sempre atento àquilo a que o Daniel responde. A que coisas ele é sensível? Para que direção vai essa sensibilidade? O que o outro faz, desencadeia o que nele?

- A imitação é um recurso valiosíssimo nesses casos - imitação é diferente de cópia. A imitação pressupõe uma intencionalidade, um envolvimento da criança. Fazer, portanto, brincadeiras que emulem o espelhamento. E um bom modo de conseguir cooperação na imitação é imitar o Daniel, fazer coisas junto com ele, fazer o mesmo que ele faz. E estar sensível ao que isso desencadeará nele, como isso vai "tocá-lo". A pergunta constante é: o quanto repercute nele aquilo que o outro faz?

- E o que é lúdico? O que dá vontade de fazer de novo (repetição) e que tem um prazer funcional (gostar de fazer aquilo, mesmo que não tenha um fim). De tal forma que não é preciso ter medo de "fazer atividades defasadas", infantis talvez, para crianças com necessidades como as do Daniel.

- Considerar que os recursos dele são, possivelmente, compatíveis com os de uma criança de 2 anos e fazer, portanto, atividades de uma criança de 2 anos. 
- Não são necessárias pautas extensas de atividades, pois isso pode sobrecarregá-lo. O cérebro e a aprendizagem precisam de tempo.

- Repetir as atividades, ensejar pequenas variações. E observar se ele capta as variações inseridas.

- Ajudá-lo a reconhecer e identificar as coisas. Repetir, reconhecer e identificar fazem parte de uma espécie de "etiquetamento" do mundo, em outras palavras, dar nome às coisas.

- Crianças são simpáticas ou antipáticas, mas não são empáticas. É o adulto que tem que ser empático, que pode pensar e assumir a perspectiva do outro. Só assim é possível facilitar o desenvolvimento da empatia na criança.

Sabemos que o sentido completo desses tópicos pode ter escapado ao leitor e pedimos desculpas por isso. Por hora ficaremos com o "quadro geral" que o Professor Lino montou: um Daniel que age no mundo por meio de uma estrutura sensório-motora, nos termos de Piaget, com tudo que isso acarreta no plano dos afetos, da inteligência, das relações, da comunicação e da imitação.

Sigamos...

Quadro 2: Autismo?

Em 28 de julho de 2016, Daniel foi avaliado pelos psicólogos Luisa e Rafael a partir da escala ADOS®, Autism Diagnostic Observation Schedule (Escala de observação 
diagnóstica para autismo, numa tradução livre). Segundo Luisa Guirado ${ }^{44}$, esta é uma escala com alto grau de confiabilidade no que diz respeito ao diagnóstico de autismo. Nela são avaliados marcos característicos desse quadro a partir de observação direta da criança $\mathrm{a}^{45}$.

Daniel faz parte de um subgrupo da avaliação: crianças que não falam. De tal forma que é desconsiderado, no score final, a pontuação relativa aos itens de fala. É necessário observar, no entanto, que há uma discriminação, no instrumento, entre fala e comunicação, esta por sua vez foi avaliada. Citamos, na íntegra, o relatório gerado pelo teste:

\section{"INFORMAÇÕES GERAIS ${ }^{46}$}

Em 28 de julho de 2016, Luisa Guirado fez observação diagnóstica sobre sinais de autismo em Daniel, de 8 anos e 9 meses. Felipe o acompanhou durante toda a observação, cuja duração foi de aproximadamente uma hora.

DADOS DE OBSERVAÇÃO

\section{Aspectos Sociais}

\footnotetext{
${ }^{44}$ Comunicação pessoal, em janeiro de 2018.

${ }^{45}$ Para mais informações, consultar (Gotham \& et. al, 2008) e (Lord, et al., 1989).

${ }^{46}$ Início da citação.
} 


\section{Comunicação}

Durante toda a avaliação, Daniel não fez uso de palavras e nem de aproximações de palavras. Em alguns momentos, vocalizou e fez isto direcionando para alguém ao seu redor com o intuito de compartilhar uma situação de prazer.

Devido ao seu atual nível de linguagem, não foi possível avaliar se há ecolalia imediata e/ou uso estereotipado/idiossincrático de palavras, nem se modula adequadamente a entonação de sua voz. Também não foi possível verificar se Daniel utiliza o corpo de outra pessoa como ferramenta ou para pegar algo que deseja.

Daniel fez uso do dedo indicador para apontar para os objetos de seu interesse que estavam fora de seu alcance, como o lanche, por exemplo. E também fez uso de outros gestos (descritivos, convencionais, emocionais, instrumentais) com intenção comunicativa espontaneamente ("não" com a cabeça, acenou tchau, deu beijo).

\section{Interação Social Recíproca}

Em quase uma hora de observação, Daniel fez contato visual de forma apropriada; respondeu ao nome na primeira vez que eu o chamei, e de forma imediata; apresentou sorriso social; dirigiu expressões faciais para o Felipe e para mim; integrou o olhar à vocalização ou ao gesto para comunicar abertura e intenção social; e demonstrou prazer de forma clara em mais de uma atividade proposta sem ser de natureza física.

Dani não fez nenhuma solicitação direta e clara ao Felipe ou a mim. Mas, foi possível notar que ele quis alguns materiais durante a avalição porque ele se dirigiu a eles fisicamente e tentou pegá-los (bexiga que estava na minha mão, por exemplo). 
Ele também não deu e nem mostrou nenhum objeto de seu interesse às pessoas ali presentes

Em relação a iniciação espontânea de atenção compartilhada, Daniel o fez de forma parcial: olhou para mim, olhou para o objeto de seu interesse, mas não voltou seu olhar para mim novamente. Em resposta a uma tentativa minha de chamar sua atenção, ele fez uso do meu apontar para guiar o seu olhar em relação a um objeto, e também fez uso do meu apontar como pista para o objeto pelo qual eu estava interessada (carro de controle remoto).

De modo geral, as aberturas sociais de Daniel foram restritas às suas demandas pessoais de busca por conforto, mas houve alguma tentativa de envolver a mim e/ou o Felipe neste processo.

A maior parte de suas respostas sociais foram restritas quanto a sua forma de apresentação (correr, querer levar os objetos à boca), e solicitou esforço meu e do Felipe para que ele se engajasse nas atividades.

\section{Brincadeiras}

Daniel brincou espontânea e funcionalmente com os brinquedos de causa-efeito, como o pop-up e a caixinha de música.

Ele não fez de forma espontânea brincadeiras funcionais envolvendo as miniaturas de objetos cotidianos (copo, prato, talher), e também não utilizou um objeto para representar, nem fez uso do boneco como agente independente. 
Quando foi solicitado que ele imitasse uma ação com um objeto previamente demonstrado por mim ele o fez, e quando solicitado que ele imitasse uma ação com objeto não demonstrado previamente, ele também o fez.

\section{Restrição e Repetição de Comportamentos}

\section{Comportamentos Estereotipados e Interesses Restritos}

Daniel apresentou interesse sensorial não usual por seu próprio corpo (fez carinho em sua barriga, pés e mão; solicitou que eu fizesse carinho em sua barriga; andou na ponta dos pés) e em bater a palma das mãos na cortina da sala.

Quanto a comportamentos estereotipados, ele apresentou um caminhar incessante entre um lado e outro da sala que dificultou que ele conseguisse permanecer sentado para brincar com os objetos no chão, ou mesmo na cadeira.

Não apresentou movimentos repetitivos de mãos, dedos, postura, nem outros maneirismos complexos (palmas não são incluídas neste módulo da avaliação). Também não apresentou comportamentos de autoagressão.

\section{Outros Comportamentos Inusuais}

Daniel apresentou certa hiperatividade de movimento corporal como um todo no decorrer da avaliação.

Não apresentou ansiedade, comportamentos disruptivos, e/ou agressividade. 


\section{Conclusão}

Concluímos, a partir da avaliação, que atualmente o nível de sinais que Daniel apresenta relacionados ao Transtorno do Espectro do Autismo é baixo, fazendo com que ele não se enquadre clinicamente no espectro.

Daniel apresenta, no entanto, dificuldades importantes que indicam a necessidade de buscarmos um diagnóstico mais apropriado, não mais relacionado aos sinais de TEA, e que talvez seja um diagnóstico de base que sempre esteve com ele, mas que foi camuflado por um tempo devido aos sinais associados ao autismo.

O quadro de autismo está configurado, neste momento, como secundário a um outro quadro mais amplo; como uma comorbidade de outro diagnóstico.

Sugerimos, assim, que seja feita uma investigação neurológica, neuropsicológica, fonoaudiológica e genética, para uma melhor compreensão dos atuais sintomas (ausência de fala, dificuldade de planejamento e execução motora, alterações sensoriais, hiperatividade de movimento) e provável causa. Isso tudo para que o Daniel possa receber o tratamento mais adequado possível conforme sua atual condição.

Colocamo-nos a disposição para quaisquer dúvidas e/ou esclarecimentos." ${ }^{47}$

${ }^{47}$ Fim da citação. 
O resultado da escala ADOS®, portanto: pelos critérios da avaliação, Daniel “está fora" do espectro do autismo.

Sigamos...

Quadro 3: sensações, corpo e praxia.

Daniel fez uma avaliação com Telma, Terapeuta Ocupacional que há anos trabalha na área de integração sensorial ${ }^{48}$, uma especialização possível da profissão. Segue resumo das conclusões e hipóteses de Telma, segundo seu recorte teórico-metodológico:

- Dificuldade na compreensão de comandos e tarefas;

- Dificuldade no planejamento motor que impactam o desempenho em diversas tarefas;

- Busca de sensação tátil, proprioceptiva e vestibular;

- Aspectos da modulação e percepção sensorial estão possivelmente comprometidos, e tende a afastar estímulos quando os "detecta" efetivamente;

48 “A Integração Sensorial é uma técnica de tratamento que foi preconizada pela terapeuta ocupacional americana Jean Ayres. [...] 'Ayres define a integração sensorial como sendo a organização de informações sensoriais, proveniente de diferentes canais sensoriais e a habilidade de relacionar estímulos de um canal a outro, de forma a emitir uma resposta adaptativa". (texto retirado do site http://www.clinicaludens.com.br/especialidades-terapia-ocupacional-integracao-sensorial.html, em 19/09/2017 às 20:05hrs) 
- Falhas nos componentes da praxia: não tem ideia de o que ou de como fazer com os objetos, dificuldade em estabelecer um alvo e se manter nele. Esquema e imagem corporal ainda precisam ser desenvolvidos.

- Por fim, Daniel teria um quadro de apraxia geral, um déficit de planejamento motor e dificuldades várias no processamento do input sensorial (sobretudo vestibular, proprioceptivo e tátil).

Sigamos...

Quadro 4: A boca-bloco

Daniel foi avaliado por duas diferentes fonoaudiólogas. A profissional Ana disse que Daniel tem uma apraxia de fala. A profissional Rosa concluiu que a "boca extensiva" (que compreende língua, lábios, laringe, etc) de Daniel é "uma coisa só", um "bloco", ou seja, ele não discrimina motora e sensorialmente seus diferentes órgãos constituintes. Quando mastiga, por exemplo, não ajustaria o movimento da boca para dar conta de triturar plenamente os alimentos, é como se a boca fizesse apenas um movimento, sem alteração para se adaptar a cada situação de mastigação. Se ele, disse Rosa, não consegue coordenar e articular os movimentos para a mastigação adequada, imagine para a fala, que requer elementos motores ainda mais finos - embora saiba-se que o planejamento motor da fala é relativamente independente da motricidade oral de uma forma geral, mas no caso do Daniel, ambos estariam comprometidos.

Sigamos.... 
Daniel foi a uma consulta com um ortopedista de uma associação referência em quadros neuromotores, com o objetivo de encaminhar um tratamento para sua marcha (Daniel, como sabemos, anda na ponta dos pés).

No plano diagnóstico, o médico disse, segundo fala da mãe, que a "questão" era neurológica. $\mathrm{O}$ que nesse caso significava algo da ordem do comando motor para a marcha e não algo ortopédico simplesmente. Ou seja, em suas palavras, Daniel precisaria reaprender a andar. Ele, segundo o médico, não saberia planejar e executar adequadamente o movimento da marcha. Foi indicado, em decorrência, fisioterapia com ênfase em reabilitação neuromotora e foi descartada, por ora, a possibilidade de intervenção cirúrgica, comum nesses casos uma vez que a marcha em ponta de pé pode acarretar o encurtamento dos tendões posteriores. Alertou ainda para os riscos de uma intervenção como esta, pois, uma vez impossibilitado, por conta do "corte" dos tendões, de realizar o movimento de marcha que lhe é habitual, Daniel seria obrigado a aprender a andar de outro modo, caso contrário, não voltaria a fazê-lo.

Daniel iniciou então tratamento fisioterápico. Segundo o que a profissional Carla avalia, a "ponta de pé" aparece em função de uma "questão sensorial" (um modo de intensificar a sensação? Ou uma reação à sua intensidade? Não sabemos...). Além disso, os anos que Daniel passou andando assim, acarretaram algumas descompensações musculares: ele teria certa hipotonia dos músculos frontais, sobretudo os da coxa e do abdômen, bem como certa rigidez muscular e déficit no alongamento. Seu trabalho iria focar em: uma estimulação sensorial progressiva aliada a uma readequação motora 
(inclusive de fortalecimento dos grupos musculares necessários) e a um processo de conscientização corporal.

\section{O mosaico}

Agora que o leitor tem em mãos as fotografias das diferentes avaliações e olhares a que Daniel foi submetido, pedimos que as coloque, todas, metaforicamente, num mesmo painel ou quadro de imagens, para que possamos traçar linhas de semelhança entre esses discursos e, quem sabe, construir uma espécie de mosaico. Comecemos pelas recorrências de termos.

Motor e sensorial são, sem dúvida, os que mais aparecem, em geral como adjetivos, que nesse caso caracterizam, além dos déficits e "questões" relativos aos sintomas, um modo de ação, uma conduta geral de Daniel.

Tomados em conjunto, as cenas construídas por essas avaliações profissionais têm um duplo efeito: configuram ao mesmo tempo um discurso sobre o Daniel e um discurso sobre o mundo do Daniel. De tal forma que elas incitam a imaginar como é estar sob sua pele. Seu efeito, portanto, não é só o de produzir um saber que se (im)põe como verdade a respeito de alguém, mas o de instrumentar a observação, alterar a lentes que usamos para vê-lo e as palavras que temos para ouvi-lo. De certo modo visitando e (in)vestindo, nós mesmos, o corpo dele, que não fala, mas que mostra... transmite... performa. 
$\mathrm{Na}$ maioria dessas avaliações algo chama atenção, a permeabilidade, certa cumplicidade e equidade entre corpo e Daniel. Como se materialidade física do gesto e da ação contivesse a profundidade da intenção, do sentimento, do sentido. Assim, bater e apalpar superfícies torna-se, nas palavras do Professor Lino, forma de expressão; levar objetos à boca, um modo de conhecê-los e conhecer a si (e à sua boca). Daniel é um corpo que cria, mas que, antes de tudo, busca sentido. E cada gesto, cada ação é uma tentativa de dar forma a si e às relações que estabelece.

É ou não completamente diverso esse quadro, onde "sintomas" podem ser considerados não como a desordem numa normalidade hipotética, mas como uma forma de constituição de ações, memórias, sensações e "identidade" possíveis a Daniel? Um quadro que é capaz de dar forma e unidade às lacunas e descaminhos produzidos nos dispositivos médico-diagnósticos que analisamos no período que vai até 2014, e por isso (e com isso) permite o desenho de uma ação possível no plano dos tratamentos/intervenções. A pergunta “o que o Daniel tem?” foi, nesse processo, reconfigurada na forma de "Como agir com o Daniel?”, em benefício dele.

Trataremos, por meio de um exemplo, dos efeitos básicos que essa formulação pode provocar no contato com Daniel, onde e quando quer que se dê (em seus tratamentos, em casa, na escola, com os pais, os colegas, etc.). O exemplo trata de uma situação prosaica, cotidiana, e que por isso cumpre sua função de retratar um modo natural de ação do pequeno: é sobre a situação de "limpar-se frente ao espelho do banheiro".

- Frente ao espelho, Daniel se olhava muito pouco, quase nunca. Mas dirigia o olhar para os outros, triangulando. Se se pedia para ele limpar a boca, e mostrávamos onde estava sujo, ele não parecia entender o que se passava, quando muito colocava a mão na boca, dentro dela, como quem chupa ou 
lambe os dedos. Por outro lado, quando não estava em frente ao espelho e recebia a mesma ordem de limpar-se, ele levava a mão ou um pedaço de papel até a boca e a limpava (não muito eficientemente, mas com “intenção" correta).

Há nessa ilustração (concreta e absolutamente frequente na vida comum de Daniel) uma espécie de dissociação: em frente ao espelho ele não fazia a mesma ação que era capaz de desempenhar longe dele.

Tomemos essa situação em análise a partir quadro referencial que montamos e perguntemos: o que está em jogo nessas situações em termos sensoriais e motores?

No espelho, há a presença da imagem refletida, muito embora ela não pareça exercer influência ou controle decisivos na execução da ação, não nos parece um regulador da ação; é como se o espelho lhe fosse indiferente, e sua própria imagem não tivesse valor diferenciado. Há também, na imensa maioria das vezes em que es sa situação ocorre, uma pia, torneira e... água. Suas mãos estão, nessas situações, quase sempre úmidas. Por conta da disposição do espaço, em geral estou atrás ou, mais raramente, ao lado dele, nosso contato visual é mediado exclusivamente pelo espelho. Ao solicitar que se limpe, aponto a boca dele, depois aponto para o espelho, nesse momento ele me olha, em triangulação, mas não olha para si, insisto, ele se olha rapidamente, ajudo fisicamente a fazer o movimento, ato contínuo a boca se abre, a língua salta e ele lambe a própria mão. Os lábios, alvo da higiene, permanecem sujos. No início desse aprendizado, Daniel “disparava" a língua mesmo quando era um terceiro (eu, por exemplo) que limpava sua boca. Era como se a equação mão-boca tivesse sempre o mesmo resultado, lamber.

Fora do espelho a situação tem alguns diferenciais. Não há a imagem refletida. Estamos, em geral, frente a frente. As mãos estão secas e, principalmente, ele segura um 
papel ou guardanapo para efetuar a limpeza, dado por mim ou indicado a ele pegar. Quando peço que se limpe, faço o movimento, como um modelo, na frente dele (a referência visual, nesse caso, é, portanto, única). Se demora para executar, repito o pedido, e quando é o caso, dou uma pequena ajuda física. Daniel não abre a boca nem põe a língua para lamber, simplesmente passa o papel ou pano nos lábios, limpando-se.

São, essas, duas situações cujo "produto" da ação seria (ou deveria ser) o mesmo: limpar-se. O movimento exigido seria, também, rigorosamente o mesmo: levar a mão até a boca e, sem abri-la, esfregar levemente. Muda, no entanto, o conjunto das “sensorialidades" envolvidas no processo: a água, a mão nua, o guardanapo, a referência visual, o posicionamento dos corpos no espaço, a imagem no espelho. Para Daniel é como se todo o resto se alterasse por decorrência; é como se aquilo que se sente no corpo alterasse completamente a ação do corpo. O movimento já não é o mesmo, o produto, igualmente. Não se trata mais de se limpar quando está com as mãos molhadas em frente a uma pia e (por acaso) um espelho, mas de molhar a boca, sentir a umidade e frescor da água na mucosa bucal, enfim, todo o prazer que puder se dar.

O espelho com que iniciamos o exemplo é objeto contingente, sem carácter diferencial na percepção de Daniel. O que parece, aí sim, fazer uma marca na regulação da ação é o conjunto de sensações táteis e proprioceptivas. O que está dissociado, nos corrigindo, não são os comportamentos, mas os diferentes conjuntos de modalidades sensoriais, que no caso do Daniel, exercem especial (quase total) influência em sua ação.

Quando o levamos para a frente do espelho e mostramos onde está sujo, esperamos que, como nós, ele se veja e faça o movimento de limpeza referenciado a essa imagem visual de si. Mas o que acontece não é isso, e parece significar que o movimento de Daniel não está referenciado na imagem do espelho, mas na "representação" tátil do conjunto 
mão-boca-água ${ }^{49}$. É nesse diapasão que se produziria a ação de Daniel, segundo esse quadro (o mosaico que produzimos). Nesse caso, portanto, ela não é, do ponto de vista dele, inadequada, disruptiva, errada. Antes, é um modo de atuar no mundo, sobre os objetos, sobre si, que leva em consideração um conjunto de referências diferentes; talvez menos compartilhadas, mas reais e concretas para ele. De tal modo que, para viabilizar outras formas de ação no processo de convivência com o contexto cotidiano, será necessário considerar essas especificidades na preparação de "estratégias do ambiente de aprendizagem" 50 .

Essa é, sem dúvida, uma construção. Possível, é verdade, mas com carácter de hipótese e de uma hipótese suportada pelo enlaçamento de tantos organizadores. Sem diminuir seu valor por conta dessa constatação, acompanhemos seus efeitos possíveis, como entendimento e encaminhamento de "planos de ação".

Um dos efeitos principais dessa ideia é o de permitir pensar sobre Daniel e sua relação com o mundo, a partir do sentido (direção) de seu comportamento em uma situação específica. Sendo assim, se deve considerar que os estímulos para ele relevantes são possivelmente diferentes daqueles a que um adulto dá atenção quando na mesma situação. O "mundo" de Daniel, possivelmente análogo (nesse aspecto sensorial) ao "mundo" de um bebê, tem tons e relevâncias de perceptos radicalmente diferentes do “mundo" de uma pessoa adulta. É como se Daniel buscasse algumas sensações ou padrões

\footnotetext{
${ }^{49}$ Nos termos de Spitz, é como se a percepção por contato (tátil) suplantasse a percepção a distância (visual) (Spitz R. A., 1965/2004).

${ }^{50}$ Essas estratégias aparecerão ao longo dos próximos capítulos.
} 
sensoriais específicos em determinados contextos, a partir de um conjunto de referências e memórias. Se ele busca, e tão intensamente, sensações, de um tipo ou com certas qualidades específicas e, em alguma medida, alheias às que os outros tem acesso cotidianamente, e se é isso que Daniel tem como a sua "realidade sensorial", não parece adequado ao bom senso privá-lo ou impedi-lo de ter acesso a elas. O que fazer então? Não se sugere, de forma alguma, que comportamentos como o de lamber a mão quando deve limpar a boca sejam incentivados. Considerar que certos componentes da atividade perceptual, da ação motora e da cognição tem um papel determinante na ação não significa, por implicação imediata, que essa ação seja adequada socialmente ou não deva ser alvo de uma intervenção. Pelo contrário, é a intervenção que deve ser enriquecida com essas informações. Alterando-se, portanto, o lugar de atuação dos interlocutores de Daniel, com isso o contexto e, quiçá, a ação desse pequeno.

O papel de quem media as relações dele, então, pode ser o de apresentar e instigar novas e mais ricas formas de contato com o mundo, na tentativa de ampliar esse universo sensorial. $\mathrm{O}$ adulto pode nomear, caracterizar os meandros dessas sensorialidades. Pode, ainda, mediar, amplificando ou diminuindo o impacto desses estímulos sobre ele. Pode contextualizá-los, preparando sua aparição e ambiente. É algo análogo ao modo, sem muito pensar, como cuidadores (sejam familiares ou não) interagem com bebês, filtrando estímulos ambientais, conversando e emprestando o sentido de suas palavras às suas ações, sem exigir deles a execução de "comportamentos funcionais". Para os bebês, basta interagir e descobrir o mundo, e o adulto é peça fundamental nessa empreitada. Se Daniel tem especificidades nessa ordem, por que fazer diferente?

Como equacionar, então, esse modo de interação com o mundo com as exigências de contexto e tempo? Pois, é verdade, Daniel tinha 9 anos de idade à época, e se comportar 
como um bebê e ser tratado como tal não são alternativas para seu desenvolvimento saudável. Exigir dele, por outro lado, comportamentos, atitudes e pensamentos compatíveis com os das crianças de sua idade, também não irá auxiliá-lo em nada, só provocará, no mínimo, frustração (nele e em nós).

Os caminhos, mais uma vez, são pelo específico, pelo singular.... Nesse sentido, facultados pelo quadro construído, escolhemos direcionar o olhar para o Daniel e não para a tarefa. De tal modo que o norte não fosse a atividade, a melhor técnica para executá-la, sua forma mais funcional ou eficiente. Antes, o objetivo seria imaginar/observar como e o que fazia sentido para Daniel. E tomar isso como uma postura de ação e conduta, que permita configurar um campo discursivo comum, minimamente compartilhado, no qual a ação de um corpo pudesse produzir sentidos e efeitos na ação do outro.

A essa altura, exemplos fazem-se necessários. Sigamos com a mesma situação de limpar-se frente ao espelho.

Quando percebemos a dificuldade de Daniel em executá-la, ato contínuo, pensamos "ele precisa aprender isso". Configurou-se então um objetivo geral: limpar-se utilizando o espelho como referência. Os motivos dessa escolha são variados, mas tem uma linha que os liga: ele está com 9 anos de idade e na maioria dos aspectos da sua vida e cuidado consigo é grosseiramente dependente de um adulto. Em uma palavra, autonomia. Limpar-se é só um de seus aspectos.

Pois bem. Como fazer isso? Por um conjunto de motivos pensou-se: "se ele discriminasse as partes de seu corpo e de seu rosto, seria mais fácil”. Na ocasião não tínhamos hipóteses tão bem estabelecidas como as que aqui apresentamos, mas, "no calor 
do momento", nos apoiamos na ideia de RTI (Response to Intervention) ${ }^{51}$ : se estivéssemos certos, veríamos os efeitos, caso contrário reavaliar-se-iam os procedimentos.

Esses consistiram em uma série de intervenções que visavam a "chamar a atenção" de Daniel para o seu próprio corpo, seja em sua representação tátil, cenestésica ou visual; preferencialmente procurando integrá-las, na medida do possível.

Abaixo segue a lista das intervenções que fizemos. Não constituem, em seu conjunto, nem uma regra, nem um manual; elas foram inspiradas a partir de uma pesquisa em livros sobre atividades para conscientização corporal, troca de ideias com outros profissionais, internet e ideias próprias. São uma espécie de construção.

- Quebra-cabeças e desenhos de rosto para montar e combinar suas partes.

- Estimulação tátil e proprioceptiva do próprio rosto e corpo, com ou sem espelho.

- Limpar marcas de tinta ou tirar pedaços de fita colocados no rosto e corpo.

- Estimulação tátil e proprioceptiva de outras partes do próprio corpo, com ou sem uso de outros objetos (massageadores, bolas em gel, etc.)

- Atividades motoras de um modo geral, com ou sem uso de objetos: andar de costas, andar sobre colchonetes em círculos, puxar e/ou se enrolar em cordas, andar sobre cordas ou linhas, carregar ou empurrar objetos

\footnotetext{
${ }^{51}$ A ideia de resposta à intervenção (RTI, do inglês) nos foi apresentada pelo professor Fernando Capovilla, a quem agradeço no momento, em aula ministrada no curso de pós-graduação do IPUSP, em 2016. Segundo o professor, há situações do intervenção em que não há tempo hábil para verificar todas as variáveis de modo a definir a melhor estratégia de atuação, nesses casos, o profíssional que está "na linha de frente" pode optar por determinada estratégia e verificar se há alguma resposta positiva a ela, em caso negativo, muda-se a estratégia.
} 
grandes como cadeiras ou colchonetes, usar bastões durante uma caminhada, subir e descer de bancos, engatinhar, entre outras.

Com isso objetivava-se que Daniel pudesse sentir e mover seu corpo de modos novos, inusuais para os seus padrões, propiciando, por hipótese, um aprendizado e uma descoberta sobre si, seus modos de sentir (percepção) e agir.

Em termos técnicos as atividades eram semiestruturadas ou semidirigidas. Com isso queremos dizer que a primeira coisa que era feita não era um treinamento, mas uma apresentação do material ou da atividade para ele e eram observados os modos como, por conta própria, atuava sobre e nas situações. Sendo assim, nossa postura era mais a de um provocador, menos a de treinador. Por exemplo: em um ambiente amplo da escola, montávamos um círculo (com diâmetro de aproximadamente 3 metros) com colchonetes e observávamos: Daniel perceberia a alteração no ambiente? Que sinais daria dessa percepção, caso ela ocorresse? Ele se interessaria pelo "objeto" novo? O que faria? Como reagiria? Em seguida, acrescentavam-se elementos de diversas ordens, a fim de enriquecer a atividade ou o contato com o material.

No exemplo supracitado, Daniel foi até o círculo e começou a andar sobre os colchonetes, dando repetidas voltas, olhando onde pisava, como que seguindo o traçado e ao mesmo tempo sendo guiado por ele. Era como se a pista que havíamos construído oferecesse contorno, forma e uma espécie de sentido ao seu andar.

Nas repetições que ele fez dessa atividade, inserimos pequenas, às vezes sutis, alterações. Alterações de carácter sensorial, como andar sem o tênis, ao que ele reagiu andando com a sola do pé plenamente apoiada no chão. Alterações de carácter espacial, 
como mudar a forma da pista (triângulo, quadrado), o que o fazia sair um pouco do trajeto ao que parava e retomava o caminho. Alterações de movimento e ritmo mais gerais, andar de costas, mais lenta ou rapidamente, engatinhando - para algumas dessas era necessária ajuda física -, o que fazia Daniel nos olhar e sorrir e, às vezes, repeti-las por iniciativa própria.

Não havia, em nenhuma dessas atividades, um modo correto de executá-las. Configuravam-se mais como disparadores de possibilidades. Isso, por sua vez, não implicava que deixaríamos de apresentar a Daniel o modo mais comum de executá-las. Por exemplo: não deixaríamos de mostrar que é possível, também, puxar ou pular uma corda, embora ele preferisse se enrolar nela.

Assim configuraram-se situações múltiplas e diversificadas, mas com vetorações coincidentes: o corpo, seu movimento e sua percepção (e, por hipótese, sua "representação" psíquica). Como dissemos, o procedimento, por conta de vários fatores, era o de resposta à intervenção. Então, qual foi a "resposta"?

Uma resposta esperada era a de que Daniel se limpasse em frente ao espelho. Isso aconteceu na primeira semana de maio de 2016. Na ocasião escrevemos:

"Fomos até o banheiro, a boca estava suja de requeijão e eu lhe disse isso; ele olhou no espelho, foi com o dedo até ela, controlada, suavemente, e limpou." (Diário de campo)

Mas, além do comportamento específico de limpar-se, uma série de novos comportamentos, ações e movimentos "apareceram" no repertório de Daniel; a maioria de criação própria dele ou executados de forma absolutamente espontânea (como uma 
lembrança "motora"), no contato com os outros, com os objetos, com o mundo de uma forma geral. Seguem alguns exemplos:

- Andar de costas espontaneamente;

- Arrastar-se no chão (soldadinho);

- Subir escadas de costas;

- Pegar no braço de alguém e direcioná-lo ao que quer (aqui tem um carácter eminentemente comunicacional);

- Levar o objeto que quer até alguém que o ajude a manuseá-lo;

- Empurrar alguém pelo braço como um pedido para "correr";

- Comer sem esmigalhar o alimento;

- Empurrar a mesa de modo a abrir espaço para sentar;

- Puxar uma cadeira e subir para alcançar algo que está no alto;

- Levantar o braço para indicar que quer se levantar ou sair do lugar onde se encontra.

Esses dados, novos acontecimentos no plano motor, apareceram na sequência dessas intervenções cujo alvo era o corpo, como sensação e movimento. E seu efeito foi o de possibilitar a essa corporeidade-Daniel formas um pouco mais plásticas e dinâmicas de ação, com sentidos e direções diferentes; marcas na singularidade da comunicação corporalmente contundente deste menino. 


\section{Capítulo 4.}

\section{Corpo, movimento e sentidos}

\section{Uma breve retomada}

Na segunda parte do capítulo anterior, configuramos uma espécie de mosaico para dizer sobre o Daniel, naquilo que nos fosse possível descrever analiticamente. Formamos, assim, um quadro que apontava para certa equivocidade entre Daniel e corpo, uma vez que este figurava como um índice forte e característico nas relações que estabelece e nos modos de ser/agir. Seu corpo físico e seu movimento concreto parecem ser os meios e os instrumentos de contato do Daniel com o mundo e com as pessoas com quem se relaciona. O que parece implicar, inclusive, que as "sensorialidades", de toda ordem, têm um papel central na configuração das ações e das respostas que o Daniel dá àquilo que o cerca. É o “mundo dos simples", para retomar um termo de O. Sacks (1997)...

Partiremos desse ponto na escritura deste Capítulo 4, já que, supomos, é pelas particularidades desse "modo de ser" que Daniel produz sentidos nas relações que estabelece vida a fora, nos diversos âmbitos de sua vida.

É à analítica desses modos de produção de sentidos que se dedica, portanto, esse capítulo.

Como muito se disse até aqui, faremos um breve retomada daquilo de mais significativo que dissemos sobre Daniel e este trabalho nas páginas precedentes, de modo a que o leitor refresque sua memória e sigamos juntos deste ponto em diante. 
Em função disso, pedimos licença ao leitor, mas as palavras que se seguem são, em sua grande maioria, repetições quase literais de trechos escritos anteriormente.

No que diz respeito a este trabalho dissemos à altura da página 36:

A análise que aqui fazemos será como um desenho possível, num contexto específico, de uma história, também, possível de um si.

Nesse (nosso) caso, o Daniel, "sua" história e "seus" modos de ser seriam esse desenho possível. E as aspas denunciam justamente esse arranjo em rede, pluriforme e caleidoscópico, dos registros e marcas, muitas vezes sem autor ou sujeito, da história da vida desse menino, cuja incomunicabilidade não o privou de se relacionar com os outros em contextos institucionais diversos, não o privou de um exercício singular de um lugar institucional. Será tarefa de nosso texto, como pesquisa, a narrativa dessa história na indeterminação dos emaranhados da rede desse bloco mágico de sua vida.

E nesse capítulo 4, mais do que em qualquer outro, Daniel e esse "desenho possível" é que estão em evidência. E isso porque será por ele que poderemos sustentar a hipótese inicial deste trabalho. A saber:

Daniel também faz registros, deles compõe memórias em rede, que carreia, como “expectativa", nas novas relações que estabelece vida a fora. Ele também traz consigo a memória marcada das relações que viveu e vive; é o bloco mágico do Daniel. Por isso, apostamos que, além de nós, ele também preserva uma história de si. Sem palavras como as nossas, que possa nos falar...

É sobre essa "aposta" que o presente trabalho se estrutura como o desafio de uma análise institucional do discurso do Daniel; uma analítica da subjetividade. 
Especificamente sobre Daniel, dissemos (altura da página 45) que há certos traços gerais no modo de ele ser que resistentemente, no tempo e no espaço, marcam sua atuação e ação no mundo. Foram eles.

\section{Fala}

Daniel não fala. Ao longo de alguns anos de nosso acompanhamento, apenas duas vezes foi possível discriminar algo próximo de uma palavra: "areia" (que ele disse a-e-ia, como quem canta uma música) e "não" (ão). Apenas isso é que pudemos observar. Muito embora ele tenha voz e emita sons frequentemente (quando ri, quando chora), ela parece sair involuntariamente nessas horas, como um efeito colateral de outras ações.

\section{Movimento}

Daniel não para. Está perenemente em movimento: quando em pé, anda de um lado para o outro, às vezes dispara em corridas. Quando sentado, os dedos não sossegam, estão sempre a girar objetos, qualquer objeto. As palmas de sua mão estão sempre vermelhas ou calejadas, pois bate com elas na maioria das superfícies, sobretudo batentes de janelas; sem sentido aparente, a não ser o de bater, simplesmente. Por alguns períodos, apenas, é que pode diminuir a intensidade desses movimentos, em geral sob medicação ou quando está muito cansado, mesmo assim, não é algo que se possa registrar sempre; diminuíram, isso sim, ao longo dos anos, as expressões de desagrado e de desconforto associadas a essa "agitação (com o uso de medicamento).

Ele é grande, maior que os garotos da mesma idade (está hoje com 10 anos). E parece ter ainda mais, pois anda sempre na ponta dos pés.

Sem dúvida, as mãos e corpo inquietos e a ausência de fala são suas maiores marcas. Quem é o Daniel? O menino que não fala e não para. 


\section{Choro}

Daniel chora, às vezes copiosamente, e como se fosse um bebê, ficamos todos ao redor procurando interpretar "o que", "por que" chora.

Quem mais de perto convive com ele, aprendeu a ler alguns sinais de desconforto. Muitas vezes essa "interpretação" é de que está com fome, ou de que está com vontade de ir ao banheiro, ou de que é alguma resposta ao impedimento de sua ação. Mas ainda mais frequente, de que está com algum tipo de dor, sobretudo quando leva as mãos e bate na sua cabeça.

\section{Intensidade e força}

Dissemos em outro lugar, Daniel é intenso e forte, na "alma" e no "corpo". Suas demonstrações de afeto, que se mesclam a uma autoestimulação, também são assim: fortes. Quando está muito animado, por exemplo, abraça a pessoa querida e leva sua cabeça até seu próprio peito, ou dirige seu antebraço à boca dessa pessoa, para que ela lhe dê "mordidinhas". Não há limite para essas expressões, ele agarra os cabelos, usa toda sua força para puxar; e cabe à pessoa, alvo e agente do carinho, prover o controle necessário à situação, evitando que ele e ela se machuquem. Mesmo assim, são frequentes pequenas lesões: uma mordida mais forte aqui, um arranhãozinho ali.

Com a mesma força que vem o prazer, vem a dor. Quando Daniel chora, é como um grito fundo e sem fim. Seus músculos se enrijecem, suas cordas vocais parecem que vão romper e sua pele, extremamente branca, avermelha-se e estoura de calor. E isso é mais frequente do que se desejaria. Em situações-limite, não há contenção física ou afetiva que lhe dê conforto; a impressão é que não há o que o fará parar de chorar até que o cansaço desse esforço caia sobre ele. 
A maioria de suas expressões e comportamentos são imediatos. Se vê um doce, ele pega e leva à boca. Se vê algo que parece interessá-lo, desenlaça-se de qualquer impedimento e vai até lá. Se "quer" um carinho no peito, abraça e ponto (às vezes esmagando alguns óculos, derrubando objetos e alimentos que estejam no caminho). Se “quer” correr, corre. Se “quer” pular, pula. Se vir água, se molha. Sem aviso e sem sinal, ele se lança, abrupta e subitamente, a essas sensações e experiências.

\section{Sensações}

Aliás, essa é uma outra característica de Daniel. Seu universo parece ser constituído basicamente por "sensorialidades". O seu mundo é aquele que suas mãos, olhos, boca e nariz alcançam e sentem. Por exemplo, quando fomos, certa vez, cozinhar biscoitos, toda tarefa que lhe era proposta (apertar a massa, usar forminhas para fazer formas de biscoito, usar o rolo, etc.) eram substituídas por uma única ação: pegar qualquer pedaço de massa (crua) que estivesse a seu alcance e levar à boca.

\section{Sentimentos}

Em meio a todas essas formas erráticas de expressão, a todos esses comportamentos “automáticos", enfim, em meio a esse Daniel "que não fala e que não para”, ele é também, na mesma medida, carinhoso. Daniel olha nos olhos, forte e intensamente. Gosta de contato físico e busca muito o rosto de outras pessoas, onde passa a mão. Basta que alguém tenha uma "cara boa" e "dê uma brecha" que ele abraça, mesmo sendo um desconhecido.

Nesses momentos privilegiados, Daniel chega a se envergonhar - como quando passeava comigo no parque e viu algumas crianças que lhe retribuíram o olhar. Diz de seus afetos e desafetos - como quando, ao levá-lo para casa depois de um passeio muito 
prazeroso, ao ver a avó vir abraçá-lo lhe virou as costas e segurou na minha mão com força. Tenta se sentir seguro - como certa vez, quando uma pessoa relativamente desconhecida dele veio cumprimentá-lo e ele alternava o olhar receoso para ela e depois para mim, como quem pergunta se está tudo bem.

\section{Acompanhamento}

A contrapartida das repetições dos modos de ser do Daniel é a constância (e repetição, também) de nossa presença e de nossas ações com e em relação a ele. De tal forma que se moveu uma ligação entre nós. Mas ele, por seu lado, permanece impossibilitado de dizer, com palavras, dessa ligação.

É assim que, por recorrências e repetições de nossa parte, se fizeram possíveis algo de novo e de mudança. O menino que não fala passou a dizer, sem palavras, um pouco de si: se utiliza de seu corpo como instrumento de ação sobre os outros (como comunicação, portanto). Aos poucos, à presença cativa desse psicólogo que, literalmente, o acompanhava em seu movimento constante, se fez seguir o primeiro gesto de comunicação de Daniel: pegar na minha mão e direcioná-la àquilo que ele deseja (à porta, ao doce, à geladeira, ao carro, etc). Se Daniel corria, corríamos também, se ele andava, estávamos a seu lado, onde quer que fosse, no tempo em que estávamos com ele, poderia contar com a presença física e concreta de nosso corpo e de nossa atenção, invariavelmente à sua disposição, para a relação, a interação, a comunicação.

\section{Comunicação}


Essa comunicação por gestos ${ }^{52}$ - com o uso do corpo, de forma pouco discriminada e apoiada em elementos de necessidades sentidas (as "vontades" do Daniel) - é, como tudo neste capítulo, exemplar deste menino, no sentido de um corte em todas as repetições antes apresentadas. Acabou por se configurar também como uma recorrência: o uso do corpo como meio e suporte da comunicação.

Comunicação que é, para ele, um desafio constante, uma vez que parcial e opaca, limitada a um conjunto de reduzido de gestos e carente sempre de um contexto que lhe seja favorável, na atenção dispensada, na disponibilidade e no entendimento. Limitada também pelas possibilidades de uso do próprio corpo, pois Daniel parece não saber o que fazer, como fazer, com seus dedos, suas pernas, suas mãos, braços, cabeça.... Um corpo que parece sempre precisar de alguma escora para agir, um guia externo que indique como usá-lo para determinado fim. De tal modo que Daniel não reproduz modelos de posições do corpo (imitar) - uma mão fechada, mão espalmada, por exemplo -, mas é capaz de aprender posições simples se for "colocado" nelas, ou seja, se se fizer com seu corpo e no seu corpo o movimento. Um exemplo disso foi o aprendizado do gesto de "não" (balançar a cabeça): inicialmente, nos momentos em que imaginávamos que as ações dele significavam uma recusa, púnhamos a mão em seu rosto e o ajudávamos (fisicamente) a fazer o movimento. Algum sentido disso ressoou nele, de tal modo que em determinada ocasião, ele pegou minha mão, levou a seu rosto e balançou sua cabeça. Ele parece ter registrado não só seu gesto de não, mas toda a situação de aprendizagem, incluindo minhas ações. Hoje, ele faz por si próprio o gesto.

${ }^{52}$ Não se trata de Libras. 


\section{Corpo}

De um lado, há seu corpo, de outro, seu movimento, entre um e outro Daniel se perde na impossibilidade de organizar seu movimento no corpo, ou seu corpo em movimento. Assim, ações simples, como abrir a embalagem de algum alimento, vestir-se ou ir ao banheiro, precisam constantemente desse "manual de como se faz", ao risco de ele não as realizar (o que é o pior) ou “dar seu jeito". Se for um alimento, por exemplo, é bastante provável que ele tente mordê-lo sem retirar a embalagem. Dessa forma, ensinar/aprender como fazer é mais uma das exemplares recorrências na vida do Daniel.

\section{Dos registros}

Ao longo de cinco anos, e com mais frequência e regularidade nos últimos quatro (2016, 2017, 2018 e 2019), acumulamos um volume considerável de registros sobre o Daniel, sob diversas formas: $a$. fotos (na casa dos milhares) e vídeos (centenas deles); $b$. diários de campo, com descrições de eventos e situações do dia-a-dia de Daniel; $c$. relatórios do acompanhamento que fazíamos, com carácter mais técnico e analítico, por vezes apresentados aos pais ou outros profissionais; $d$. um dossiê, no qual eu, além das situações concretas, escrevia minhas impressões, entendimentos, dúvidas e considerações sobre elas; e $e$. inegavelmente, há também os registros dessa história que tenho na minha "memória pessoal".

São esses registros o material-base de qual partem as cenas analíticas desse capítulo. Muitas delas (das análises), no entanto, foram produzidas no mesmo ato de 
registrar, isso porque, como já dissemos, eu pensava ${ }^{53}$ com a AID o próprio acompanhamento terapêutico do Daniel, enquanto ele acontecia, de tal modo que, muitas vezes, quando pegava a câmera de meu celular para uma foto, por exemplo, era porque eu via a possibilidade de retratar numa imagem o "sentido" produzido naquela determinada situação. E um sentido que enlaçava inclusive a mim.

Por tudo isso, consideraremos os relatos apresentados nas páginas seguintes como analíticos. Podemos dizer, inclusive, que são descrições analíticas a partir de uma observação atenta, para retomar termos conceituais deste trabalho.

${ }^{53}$ Embora tenha usado "Eu", devo acrescentar que se "eu" pensava assim, era tão só porque tive a oportunidade de ser supervisionado, orientado e acompanhado nesses trabalhos por Marlene Guirado. E muitas vezes, quando eu estava em contato com Daniel, as palavras da minha supervisora/orientadora ressoavam a me guiar. 
Das impressões e expressões de um corpo à produção de sentidos: a singularidade no/do discurso-ato

Como sugere o título, neste item abordaremos aquilo que se apresenta como os modos de expressão de Daniel: os desconfortos, as dores e os prazeres que, sinaliza no corpo, o atingem e que sente. Para isso nos fiaremos, no entanto, em um procedimento de escritura que exige a tomada de diferentes situações e a apreciação de elementos variados que nos permitam configurar o contexto amplo, por vezes complexo, que dá lugar e sentidos a essas formas de expressão.

Atravessando todas essas situações está Daniel, que age e reage como pode às exigências diárias que lhe são feitas. Essas, muitas vezes, ao virem de fora, dos outros que com ele se relacionam, podem ignorar as "condições internas", pessoais, que ele tem para responder num determinado momento. Por isso descreveremos alguns dispositivos e relações (institucionais), assim poderemos analisar e demonstrar que, muitas vezes, o desencontro entre o Daniel (com suas demandas e necessidades específicas) e a resposta, ou pior, a ausência de resposta do ambiente concreto que o cerca pode dar origem a formas muito agudas de expressão de sentimentos e sensações, sobretudo essas de caráter desconfortável.

Por fim, nesse caminho, seremos levados a pensar justamente sobre essas especificidades que compõe os modos de sentir e agir do Daniel, que requerem inevitavelmente que o contexto e o ambiente se alterem para abarcar essa gritante corporeidade. Pois, é de destaque que um garoto de onze anos de idade seja, ainda, tão sensível a desconfortos relativamente corriqueiros, como fome e sede, indicando que desequilíbrios internos (orgânicos, fisiológicos, relativos à homeostase do organismo de 
uma forma geral), por menores ou mais comuns que sejam, podem assumir facilmente o primeiro plano e influenciar diretamente sua conduta, devido à singular expressividade de sua comunicação.

No que tange aos efeitos das (im)possibilidades de negociação entre as expectativas de Daniel, seus estados internos e o contexto e ambiente imediatos, a entrada, no final de 2016, em uma instituição marcada pela disciplina e pela ordem foi exemplar, infelizmente... Descreveremos na sequência as práticas dessa instituição, pautadas mormente num exercício de disciplinarização do corpo e do movimento, que, por sua vez, como efeito sobre o Daniel, acentuaram esse modo de "funcionamento" que está na base de suas expressões de sofrimento, desconforto e dor. Essa situação concreta levou ao limite as exigências de controle que pesavam sobre um corpo ativo e, além do mais, avesso a constrições. Acompanhemos seus efeitos.

Como dissemos, desde de o ano de 2016 Daniel frequenta, no período matutino, essa instituição, que atende "crianças com autismo". Seus pais acreditavam que "era disso que ele precisava", e batalharam junto à direção do lugar para que ele fosse aceito. Ela é conhecida e se faz conhecer como um lugar que preza pela disciplina e regramento da conduta, sobretudo no que diz respeito aos cuidados consigo e com o ambiente em que a criança vive. Assim, sua clientela é submetida a uma rotina rigidamente estabelecida de atividades, numa sequência determinada, inclusive nos tempos de seu início e fim, bem como no modo que deverá ser executada determinada tarefa. 
Concretamente isso significa: chegar ao local na hora marcada para a entrada, às oito da manhã, onde a criança é recebida na porta por um dos agentes institucionais, que a cumprimenta com uma saudação (como aquelas reverências que se fazem antes de uma luta de judô ou karatê), e a criança deve responder do mesmo modo ${ }^{54}$. Sua passagem é liberada e ela deve entrar e sentar em um banco, aguardando seus parceiros, até que sejam todos chamados para a próxima atividade, a "troca". Esta consiste na mudança de roupa, em que a criança deve retirar sua vestimenta, dobrá-la e armazená-la em seu respectivo espaço no armário, depois, se vestir novamente com o uniforme da instituição. Seguem todos para a rua, devidamente uniformizados, em fila e com as mãos para trás, onde caminham até uma área a alguns quarteirões em que iniciarão a "corrida", a próxima atividade. É terreno asfaltado, relativamente espaçoso (do tamanho de duas quadras de futsal, aproximadamente), onde cones estão dispostos a fim de demarcar um percurso oval. Além deles, nada mais indica o traçado em que a corrida será realizada. Clientela e agentes institucionais devem, então, correr ou trotar por esse percurso ao longo de trinta minutos aproximadamente.

Algumas crianças, talvez sua maioria, realizam a corrida "obedientemente", seguindo o ritmo do grupo e o percurso padrão. Outras se destacam do pelotão; por diferentes motivos, algumas correm sem respeitar a "ordem" pouco clara imposta pelos cones, outros simplesmente sentam no chão, há os que andam morosamente e ainda os que, mais incomodados, choram e se batem. Ouve-se a todo momento gritos dos agentes

\footnotetext{
${ }^{54}$ Inclusive Daniel. Mas ele não costuma responder espontaneamente então, na maioria das vezes, alguém maneja seu corpo e força um pouco seu tronco para ele realizar o cumprimento. Provavelmente, não entenda quase nada desse contexto e desse ato.
} 
institucionais: "Vamos, pessoal!", "Vai, Silva [sobrenome], não para não!”, etc... E, por vezes se vê um ou outro ir buscar algum menino ${ }^{55}$ que corre sem direção naquele espaço aberto, para recolocá-lo na marcha do grupo. Os que sentam são levantados pelas mãos ou pelo tronco e também recolocados na corrida. Em contraste com os gritos de "incentivo", nesses outros momentos (os disruptivos) os agentes institucionais pouco falam com as crianças, apenas agem sobre seus corpos.

Findada a corrida, seguem, novamente em fila com as mãos postadas atrás, para a sede principal, onde respeitam uma rotina semi-escolar. A depender do cronograma do dia, são propostas atividades pedagógicas, em sala de aula; se espera com isso desenvolver na clientela a "postura de aluno", que a criança se mantenha sentada e realize sua tarefa. Intercalando com essas atividades, em outros dias, eles têm "aula de educação física", cuja proposta é basicamente a realização de circuitos psicomotores. Há, no entanto, um detalhe, os circuitos comportam número limitado de crianças (cinco ou seis), as outras devem, pois, esperar sua vez, não do modo que quiserem ou puderem, mas sentados no chão, orienta-se inclusive a manterem certa posição, abraçados aos próprios joelhos.

Por volta de onze e trinta, todos se dirigem ao refeitório, para o "almoço" (que é encarado como mais uma atividade). Cada criança deve se servir sozinha, sentar em seu lugar à mesa e aguardar até que todos tenham feito o mesmo, só depois é autorizada a comer, utilizando sempre garfo e faca (independentemente da habilidade que demonstre

\footnotetext{
${ }^{55}$ A clientela é toda formada por crianças e adolescentes apenas do sexo masculino. Embora não haja nenhuma restrição, por parte da direção, às meninas.
} 
ter com esses instrumentos). Cada um deve retirar seu prato ao término da refeição e se dirigir (sempre com o grupo!) até o banheiro para a "escovação" dos dentes. Solicita-se aos pais que enviem uma bolsinha com uma escova e uma pasta de dentes para seu filho, com uma recomendação: que a escova e pasta sejam as mesmas que os adultos utilizam (não é permitido, por exemplo, usar pastas de dente com sabores menos agressivos ao paladar infantil, ou mesmo sem flúor para aqueles que ainda a engolem). Por fim, nova "troca" de roupa e todos se preparam para esperar, sentados lado a lado, seus responsáveis para irem embora. O portão abre pontualmente às treze horas e se repete o ritual da entrada com a reverência de tronco inteiro.

A instituição Walden $G^{56}$ assim se faz diariamente. E desde a porta de entrada promete exatamente isso: que suas crianças aprendam a cuidar minimamente de si (trocarse, escovar os dentes, banhar-se, servir-se, alimentar-se, etc.), acreditam que os jovens com autismo não fazem isso por não terem adquirido o hábito, um hábito que se construiria por meio de uma disciplinarização da conduta, repetida diariamente até que a criança (ou adolescente) discipline-se a si própria e passe a ter como sua a responsabilidade que antes lhe era imposta de fora, ou ao menos que façam as atividades que a instituição propõe do modo como esta considera adequado. Mais do que a realização de uma tarefa, está em jogo, portanto, a postura, a conduta da clientela, é este o alvo das ações dos agentes institucionais.

${ }^{56}$ Nome fictício. Inspirado no livro de B. F. Skiner, Walden Two (Skinner, 1948/1975). 
No entanto, não se trata apenas da disciplina como "virtude moral" ou modelo educacional, pois nas práticas concretas dessa instituição a disciplina ganha contornos de um controle massivo sobre o corpo, as ações, os comportamentos e as condutas de sua clientela. Explicamos e exemplificamos.

Não basta à criança fazer a troca de roupas, ela deve dobrá-las e guardá-las, não de qualquer modo, mas segundo certa "técnica de dobradura", que é inclusive exaltada pela direção da instituição ao apresentar o trabalho lá realizado. Coloca-se a peça de roupa por sobre uma mesa, onde é esticada, depois dobrada ao meio duas vezes. Já para se trocar, a criança deve estar sentada, o que aumentaria eficácia do movimento e de seu controle. Os tênis não devem ser aqueles que tem velcro® no fecho, e sim cadarço, pois as crianças "precisam aprender a utilizar os mesmos objetos que os adultos, sem nenhuma facilitação ou adaptação", é o que se diz. E para isso há também uma "técnica" de amarração que lá se emprega.

Controla-se também a posição que assumem corpos, braços e mãos em diversos momentos do dia: nas filas, mãos para trás; ao esperar, abraçar os joelhos; ao comer, manter em mãos os talheres. Cria-se uma espécie de corpo-padrão que a todo momento é implantado e forçado sobre os corpos reais e movimentos singulares desses meninos.

Do corpo-padrão se exige, também, uma conduta determinada, uma espécie de etiqueta bufona. Assim, o ato de cumprimentar ao entrar e ao sair ganha ares de uma reverência litúrgica, onde as crianças, brasileiras, são forçadas a curvar seus troncos, de forma inusual e, até certo ponto, pouco funcional para nossa realidade social, na qual os cumprimentos entre os jovens costumam ser um tanto mais "descolados". Traveste-se também de formalidade o nome, pois a clientela da instituição é chamada por seu sobrenome. Tantos Pedros e Joãos se tornaram Costas e Silvas ao pisar por lá. 
Por fim, o controle se exerce também sobre o tempo e a rotina, de tal forma fixados que não admitem mudanças de rota, atrasos, pressas, desordenamentos quaisquer que alterem o pré-estabelecido. Às crianças e jovens (clientela), resta se adequar, se submeter; não há negociação ou resistência previstas na ordem discursiva dessa instituição.

Tudo que até aqui dissemos não fere as premissas de isenção na observação por parte desse pesquisador; foi, de fato, visto, ouvido, registrado, observado nas inúmeras vezes que esteve em contato com os agentes institucionais, com o ambiente físico e institucional de Walden $G$. Dessa forma, as cenas que destacamos são uma chave fundamental para o entendimento dessa prática institucional e de seus efeitos sobre a clientela, mais especificamente, sobre Daniel. Uma instituição que, tudo indica, funciona ao modelo do poder disciplinar, como analisado por Foucault em Vigiar e Punir (Foucault M. , Vigiar e punir, 1975/1977). Pois a disciplina, segundo esse autor, exerce um domínio sobre os corpos dos outros, não apenas para que façam o que se quer, mas para que funcionem como se quer. Com a técnica, a rapidez e a eficácia desejadas. "A disciplina fabrica assim corpos submissos e exercitados, corpos dóceis”. (Foucault M. , 1975/1977, p. 127).

Se assim podemos pensar, temos que o objeto de ação dessa instituição é a antítese do Daniel. A instituição força a docilização de um corpo forte, intenso e... insubmisso. Na sequência ampliaremos e detalharemos essa ideia analítica. Alguma tensão deve estar se criando. Como Daniel e Walden $G$ sobrevivem a ela é difícil de avaliar.

Como acontece em muitas instituições que recebem aos seus cuidados crianças e jovens com autismo, a discriminação das características e necessidades específicas de uma determinada criança e/ou jovem é embaçada pela nosologia ampla e genérica do 
quadro comportamental do diagnóstico psiquiátrico ${ }^{57}$. De tal forma que, Daniel, o menino que (não) tem autismo ${ }^{58}$, mais uma vez foi admitido numa instituição para “autistas" (essa Walden G). Enredado na malha discursiva dos procedimentos, sem se considerar nisso que seu corpo agitado, seus movimentos intensos, rápidos e por vezes erráticos não se submeteriam à sua ordem e disciplina. Soma-se a isso que Walden $G$ não é uma instituição-padrão, por assim dizer, pois preza, em seu exercício, por práticas disciplinares e corretivas, da conduta, do corpo, do movimento.

Logo se perceberam os sinais de descompasso. Se o leitor se lembra, foi nessa época (2016), pouco antes de Daniel ingressar em Walden $G$ que passamos a acompanhálo na escola, e uma premissa básica de nossa postura era a possiblidade de negociar, intermediar, as demandas de contexto e ambiente com as condições de o Daniel responder a elas, de modo que aquilo que ele vivesse pudesse reverberar algum sentido para ele. Assim, nos meses que antecederam sua entrada na instituição referida, Daniel quase sempre chegava à escola rindo (na parte da tarde, quando eu o encontrava), com semblante alegre. Gostava de correr com ou entre as crianças, percebia quando uma trombada se aproximava e desviava a rota ou diminuía a velocidade de sua corrida. Gostava de escorregar no corrimão de uma escada de acesso ao pátio, escalava o "brinquedão" e lá de cima mirava a tudo e todos, acompanhando os movimentos de correria de seus colegas. Por vezes, abraçava alguém que o viesse cumprimentar. Mantinha contato visual intenso e significativo com quem se dispusesse, como eu muito fiz, a interagir e brincar com ele nessas situações. Com liberdade e prazer se movimentava

\footnotetext{
${ }^{57}$ Discussão similar empreendemos no Capítulo 3. Uma historiografia Diagnóstica.

${ }^{58}$ Ver o mesmo capítulo 3.
} 
por essas áreas da escola, se aproximando ou se afastando de quem ou de quê quisesse. Eu, nessas ocasiões, apenas o acompanhava, facilitava certas interações, estimulava alguma forma de contato ou comunicação que fosse pertinente a esse contexto. Passados uns minutos da hora de entrada, todas as crianças, inclusive ele, subiriam para as salas de aula onde o dia seguiria de acordo com as programações.

Já nas primeiras semanas em que frequentou Walden $G$, ocorreu uma mudança sensível nas formas de agir e nas expressões do Daniel. Não apenas eu, que sempre fui mais próximo e atento a ele, mas boa parte do alunato e dos funcionários da escola notaram que ele estava mais "bravo". Não se via mais o semblante alegre ao entrar na escola, em seu lugar os cenhos se franziam, tornando a expressão facial algo tensa, indicando um incômodo interno qualquer. Seus movimentos também mudaram, mais fortes e "cegos", ao invés de desviar de alguém, Daniel empurrava ou trombava, de forma não intencional, mas displicente. "Passava reto", ignorando, quem viesse cumprimentálo. Não subia mais no "brinquedão", nem observava as movimentações e as pessoas ao redor. Parecia um tanto desconectado daquele contexto, um tanto incomodado e desorientado. Nesses primeiros dias, Daniel chegou a chorar bastante, gritando alto e inconsolavelmente.

De certa forma eu já havia aprendido a perceber seus sinais de desconforto. Mas que tipo de desconforto seria dessa vez? Perguntei o que ele queria, ao que apontou sua boca (indicando que queria comer com o gesto que havia lhe ensinado). Pegamos sua lancheira e nos dirigimos à mesa. Deixei que se servisse do que quisesse: ele, ao invés de abrir seus iogurtes com as pontas de seus dedos em pinça, como já tinha aprendido (no nosso acompanhamento) há tempos, mordeu a embalagem, como fazia antes de nosso trabalho. Auxiliei na abertura dos recipientes, mas ele se alimentava de modo um pouco 
desesperado, um tanto ansioso, faminto. Depois de deixar que devorasse parte de seu lanche, eu procurava fazer com que ele "retomasse o controle", acalmando-o com um carinho e uma conversa amena sobre ele e sua fome, garantindo sempre que poderia comer o quanto fosse suficiente. Depois, o levava ao banheiro, e sua bexiga estava invariavelmente muito cheia (mais um desconforto). Por fim, brincávamos e corríamos no pátio, infelizmente sem os colegas (que já haviam subido para a aula), mas era o momento em que Daniel voltava a ficar disposto e alegre.

Por força de seu estado ao chegar de Walden $G$ à escola, esse tempo de regulação, folga e prazer (no qual se alimentava, usava o banheiro, recebia carinho e ficava livre para brincar e correr) teve de ser inserido na rotina de seu acompanhamento. De tal modo que, se o desprezasse, o estado de aflição e desconforto do pequeno se elevava enormemente, e ele se desregulava muito, chorando por mais de hora, inconsolável. Seu humor se alterava sensível e repentinamente ao longo do dia, por vezes inviabilizando a execução de ações e atividades a que já estava adaptado.

Assim, se formou uma equação um tanto paradoxal. Uma instituição pautada na ordem, na docilização do corpo, no regramento da conduta, na displinarização das ações, produziu, na relação de clientela, um corpo ainda mais impulsivo, um humor ainda mais instável, um estado geral ainda mais desregulado. Daniel se tornou, no plano das relações institucionais, podemos dizer, um foco de resistência ao controle e submissão de seu corpo e de sua conduta. Uma resistência à disciplinarização, exercida por decorrência de um modo muito particular de funcionar para equilibrar as demandas "internas" (de seu corpo, de seu tempo, de suas vontades e capacidades) e as demandas "externas" a que tem 
que responder. E tudo isso sem que se possa atribuir a ele qualquer intencionalidade ou consciência dos fatos. Daniel é resistência, sem "saber" que é.

Mas, afinal, que "modo particular de funcionar" é esse que está na base de sua resistência?

Daniel reage de corpo inteiro, por totalidade, ao sofrimento e dor por ele sentidos. A tensão de seus músculos aumenta consideravelmente, o ritmo e velocidade de seu movimento ficam por vezes frenéticos e desorganizados, a delicadeza que lhe é possível em algumas ações se perde e dá lugar a uma força incompatível com a ação prevista, a feição invariavelmente tensa de seu rosto e de seu olhar, são as principais formas de expressão que comunicam, nesse seu corpo concreto, aquilo que sente. Estas praticamente não mudaram ao longo do tempo, são observáveis ainda hoje e servem de sinal de que “algo não vai bem" com o pequeno. De certa forma, ao menos nesse aspecto, Daniel é cristalino: basta olhar e com a mínima sensibilidade do observador, é possível perceber como ele se encontra, se pende mais para o desconforto e o incômodo, ou para certa tranquilidade e alegria. Trata-se de uma constatação quase imediata, gestáltica.

Esse é o estado geral que se apresenta. No entanto, as atitudes mais específicas se alteraram ao longo do tempo. Em 2016, antes de entrar em Walden G, Daniel chorava muito alto e se agitava nessas situações, mas tolerava ser abraçado, contido, acariciado e acalmado; embora "acalmar-se" fosse muito difícil para ele, seu corpo e seu movimentos não expulsavam ou reagiam a quem se dispusesse a dele cuidar. Já nos primeiros meses a frequentar Walden $G$, Daniel passou a se bater, ou melhor, bater a cabeça na superfície mais próxima, normalmente a parede, quando se encontrava nesse estado. E muito pouco se deixava conter, acalmar... parecia arredio ao toque, à presença e à proximidade. 
Essa curiosa contemporaneidade entre bater-se (especialmente a cabeça) e a entrada na instituição merece ser destacada e comentada. É que, entre todos os procedimentos de controle do corpo e do movimento lá exercidos, se encontra um para lidar com o que eles chamam ou consideram "crises". Trata-se de segurar as mãos da criança, posicionando-a de pé, em frente ao agente institucional e aguardar que a "crise" passe. Qualquer movimento da criança (correr, tentar se desvencilhar, limpar o rosto, se jogar no chão, etc.) é impedido até que ela volte a ficar mais “calma”. O adulto permanece calado, evitando dar qualquer resposta à criança “em crise”. Com isso, se cria uma espécie de batalha muda entre o agente institucional e a "crise", um dos dois cederá, mais cedo ou mais tarde!

É aí, no entanto, que Daniel é resistência. Nesse caso, inclusive física. Ele não se cala, não para, não acalma...enfim, sua "crise" não cede. E, quando está nesse estado, a escalada de seu desespero é exponencial, sendo possível imaginar que levado pelo desamparo de não ver seu sofrimento acolhido, contido, redirecionado, respondido, Daniel, com as mãos presas, arremesse-se para trás, num movimento de cabeça e tronco, acertando a parede mais próxima.

Assim, bater a cabeça ao mínimo sinal de desconforto se tornou, à revelia de todo o trabalho e acompanhamento que fazemos com o Daniel, um recurso de que ele dispõe de forma quase automática na expressão e sinalização de seu sofrimento. Uma formalimite de seu corpo "gritar" que algo não vai bem, gerada em e por um contexto que suprime toda e qualquer forma de expressão singular, que funciona pela domesticação e coação de corpos e movimentos. Há, portanto, inesperada positividade nesse autoflagelo, a da triste e possível resistência de um menino à norma e ao desamparo produzidos no exercício de um poder disciplinar. 
É comum, no entanto, outra explicação para as "crises", como se costumam chamar esses rompantes intensos e incontroláveis. De forma muito recorrente e insidiosa, não raro, profissionais (psicólogos ou não) nomeiam como crise aquilo que imaginam ser uma birra, um comportamento disruptivo qualquer, ou seja, a crise é quase sempre entendida como uma negativa desadaptada e malcriada da criança a alguma tarefa, situação, ordem, etc.

É insidiosa porque reconhece na inespecificidade do termo "crise" apenas um de seus muitos sentidos, produzindo uma automática sinonímia entre crise e birra. A esta o agente institucional não deve ceder, não deve acolher, não deve tratar, não deve responder. Assim, uma vez identificada, no bojo do discurso e das práticas institucionais, a crise-birra, aciona-se o procedimento padrão. E já sabemos qual é, no caso de Walden G. Na contramão, se ignora ou se despreza a possibilidade de a criança negar, recusar, alguma ordem, demanda ou tarefa, e isso independentemente de se saber por que ela nega, de suas razões e motivos para recusar.

Todavia, não é privilégio de Walden $G$ não dar voz à criança. Como demonstraram Guirado \& Guirado (2014/2018), é recorrente o solapamento do lugar de enunciação dessas crianças que não falam, que "tem" autismo e que são diariamente submetidas aos procedimentos e dispositivos da saúde mental (entre eles os da psicologia). A história de Daniel, até nisso, é novamente exemplar. Segue o relato e a análise de mais uma situação.

Em 2018, sobretudo no segundo semestre, por algumas semanas, ele passou a ter explosões frequentes, várias vezes ao dia, por dias seguidos, dessas expressões de sofrimento (choro, agitação, bater-se...etc.). A intensidade só aumentava, a força com que se batia era sempre maior, e cada vez esboçava menos sinais que permitissem prever o que faria, era repentino, rápido e agudo. Uma das profissionais que o atendia, ainda que 
não fosse psicóloga, não hesitou em "diagnosticar" como "comportamental" (ou seja, uma birra) essas suas explosões de sofrimento. Ela dizia que ele fazia isso para "fugir da demanda" dos exercícios que ela lhe ordenava. Atribuía-se ao seu modo singular de resistir ao sofrimento, uma intencionalidade de comunicação de oposição à ordem do outro. Intencionalidade esta que, ao que discutiremos depois, não se pode considerar como a comunicação de Daniel, mormente expressiva.

Esse "diagnóstico", emitido de forma quase automática, mais obscurece o quadro, na medida em que desconsiderou elementos importantes para o entendimento de o que se passava com ele à época. Essas semanas foram marcadas por diversos sinais de que o Daniel sofria de alguma moléstia física. Listaremos, para facilitar o acompanhamento por parte do leitor:

1. O primeiro sinal foi um sangramento em seu ouvido externo. No Prontosocorro diagnosticaram uma otite e uma pequena lesão, sem danos ao tímpano. Receitou-se um antibiótico tópico.

2. Três dias depois, Daniel ainda chorava, se batia e se beliscava de forma muito intensa, sendo necessárias ao menos duas pessoas para contê-lo de forma a não se machucar ainda mais. Fomos ao pronto-socorro novamente, onde verificouse ainda a lesão no ouvido e uma possível alergia.

3. Mais três dias, em consulta de emergência (uma vez que continuava se batendo e se beliscando) com a neurologista que o acompanha, foram observados sinais de uma forte alergia na pele (evidentes até para nãomédicos), além de um claro desconforto físico, um certo desespero nas expressões faciais e comportamentais do pequeno, nomeados dessa forma pela 
médica. Solicitaram-se exames e iniciou-se um tratamento mais intenso para conter os sintomas da alergia.

4. Uma semana depois, como ele ainda apresentava "crises" em que chorava muito e se batia, foi levado a uma consulta com uma médica que acompanha a família. Mais uma vez, foram constatados os sinais de alergia, já mais enfraquecidos, e uma afirmação categórica por parte da profissional: ele está com dores e desconfortos, mas não sabemos o que está provocando isso!

5. Por fim, quando já parecia se recuperar da alergia depois de quase três semanas, passou a ter febres e vômitos, que duraram cerca de três dias.

Daniel foi violentamente acometido por um conjunto de moléstias e desconfortos que atacaram diretamente seu corpo, causando dores e mal-estares difusos, diversos e incessantes. Isso, ao longo de quase três semanas! Além disso, alguns elementos se somaram para agravar o quadro: $a$. a indefinição diagnóstica dos médicos que o atenderam, inviabilizando que o tratamento pudesse ser presto e efetivo, alongando assim o sofrimento e atrasando a melhora do Daniel (foram quatro médicos em duas semanas e as crises, ao invés de diminuírem, só aumentaram em intensidade e frequência); $b$. por negligência de quem estava responsável por seus cuidados básicos diários, sua cuidadora, que não seguiu as orientações médicas no que diz respeito à dose e frequência com que recomendaram ministrar os medicamentos, entre eles, antialérgicos, antibióticos e analgésicos; isso porque considerava, segundo o que ela mesma dizia, que era um exagero, que o que o Daniel "tinha" não era algum tipo de dor ou sofrimento físico e, sim, comportamental; $c$. essa fala da cuidadora, curiosamente, repete e reverbera a fala da profissional (que citamos acima), causando uma espécie de desentendimento dos reais 
motivos pelos quais Daniel estava tendo "crises"; $d$. Daniel, repetimos, não fala; como poderia ele expressar tamanho sofrimento que não pelo próprio corpo?

De todo modo, nessas condições agudas de sofrimento, soa a negligência, com pendor antiético, disparar o procedimento padrão ${ }^{59}$ para corrigir a falaciosa birra.

Para quê nos alongamos nesse histórico? Para mostrar como "não dar voz" 60 a uma criança como o Daniel, que tem esse corpo, esse movimento e todas essas formas erráticas, mas específicas e singulares de expressão, pode facilmente se tornar um ato de violência. Violência porque anula toda e qualquer possibilidade de ele resistir. Quando sua resistência se transforma em birra, nas palavras de um adulto, o que mais pode ele fazer? Ele que não fala, que não pode gritar, pedir ajuda, e, além de tudo, que não consegue se acalmar, que não consegue parar.... Nesse caso, o desespero é a única forma de rebelião!

E cabe aqui uma hipótese. Daniel é levado a agir dessa forma porque não tem condições amplas de se regular, única e exclusivamente por si, de dar vazão, destino, expressão e solução às suas demandas (das mais básicas, fome, sede, dor) de forma a lhes responder adequadamente e amenizar o sofrimento por elas imposto. É necessário que o contexto também possa ter ouvidos e ser sensível a essas demandas que não se expressam em linguagem comum, mas nesse e por esse corpo, e assim responda e acolha, no bojo de suas práticas, aquilo de que Daniel precisa para se apaziguar. Acontece que, tanto Walden $G$ quanto a profissional citada e a cuidadora, pouco ou nada estavam disponíveis para

\footnotetext{
${ }^{59}$ Mormente o da extinção comportamental.

${ }^{60}$ Nos termos de nossa Análise Institucional do Discurso, não dar voz é não garantir o lugar de enunciação à criança com quem nos relacionamos. Ver (Guirado \& Guirado, 2014/2018).
} 
negociar as suas demandas (técnicas, profissionais, institucionais, etc.) com as demandas deste nosso pequeno. Produzindo assim um estado agudo de tensão no Daniel e em seu corpo, levando a também um tensionamento no exercício das relações que estabelece.

Assim, pensar em termos de regulação se tornou fundamental para a configuração dos sentidos desses discursos, o do Daniel e este nosso. Observamos também que outro termo que ganhou importância foi tensão/tensionamento. Este, caracteriza, ao mesmo tempo, o efeito desses desencontros sobre o Daniel e seu corpo, bem como sobre as relações institucionais que nessas condições ele estabelecem; elas se tornam também tensas, aflitas, inquietantes. Mas precisamos dar um passo além e responder ao leitor o que, nesse ponto de nosso texto, entendemos por regulação e tensão, essas formas de expressão e ação do Daniel.

De certo modo, isso já se anunciou nas descrições analíticas das cenas da vida deste menino, no entanto, para avançarmos em clareza, faremos também uma digressão por algumas ideias de Marlene Guirado que permitem instrumentar o nosso pensamento a partir de discursos de autores como Renée Spitz e Sigmund Freud. Será breve, logo voltaremos ao Daniel.

Palavras para um corpo: sobre contexto, relação, comunicação expressiva e memória

Já dissemos diversas vezes nesse texto que Daniel não fala. No entanto, não discutimos isso nas graves implicações para a vida desse menino que, a todo momento, é instado a estar no mundo e agir, sem pouco ou nada poder dispor de comunicação pela 
palavra e com isso equilibrar as demandas internas e externas. Não falar, nunca ter falado, não ter "atingido esse marco do desenvolvimento", não ter "desenvolvido um universo simbólico", têm, provavelmente, implicações radicais nos seus modos de expressão e de ação, de tal forma que somos levados (nós, que convivemos e nos relacionamos com ele) a fazer um esforço de imaginação para entender o que se passa quando ele sente dor, quando tem reações extremadas por motivos ordinários e às vezes, a nossos olhos, inexistentes, quando ele se bate, quando chora sem consolo possível...

Para esse "esforço de imaginação" contamos, mais uma vez e sempre, com Marlene Guirado. Além de autora do método que anima esta Tese, ela é também a professora Livre-docente responsável pela disciplina de Psicologia do Desenvolvimento II (Desenvolvimento Afetivo) neste Instituto de Psicologia. Nesta disciplina, ela faz um recorte interessado da obra de Freud para apresentar aos alunos uma possibilidade, pela psicanálise, de pensar o desenvolvimento humano. Nas últimas aulas do curso, também a partir de um recorte, apresenta aos alunos outro autor, Renée Spitz, que ampliou e desenvolveu as ideias de Freud sobre a constituição do objeto da libido e das relações objetais, bem como a gênese do Ego. Quando dizemos que Guirado "apresenta por meio de um recorte interessado" esses autores, fazemos referência ao modo nada trivial dessa autora de pensar e organizar discursos. No referido curso, ministrado em 2018, Guirado, em aula, em ato e palavra, teceu uma relação conceitual entre comunicação como comunicação expressiva (segundo Spitz) e o inconsciente como memória no bloco mágico (segundo Freud). Foi uma organização brilhante e sui generis de discursos e conceitos que, hoje e aqui, fazemos reverberar para avançar no entendimento desse nosso 
garoto, Daniel. Que, aliás, como Guirado nos disse ${ }^{61}$, animava seu pensamento enquanto expunha em aula as ideias que na sequência relataremos. Com a palavra, a professora Marlene Guirado.

Segundo Spitz (O primeiro ano de vida, 1965/2004), o início da comunicação não exige nenhuma intenção ou consciência do gesto comunicacional por parte do bebê (que, aliás, segundo ele, é incapaz dessa "intencionalidade"). Ela tem como precursor o afeto materno que se expressa, sem passar pela consciência da mãe, em posturas, gestos, na repetição de movimentos, no toque, no tom de voz, etc., que são "apreendidos", no bebê, por mecanismos dos sistemas intero e proprioceptivos ${ }^{62}$.

${ }^{61}$ Comunicação pessoal em janeiro de 2019.

${ }^{62}$ Segundo Spitz (Spitz R. A., 1965/2004), as formas de percepção poderiam ser classificadas como percepção por contato e percepção à distância ou, para sermos conceitualmente mais rigorosos, recepção cenestésica e percepção diacrítica, respectivamente.

A caracterização do sistema cenestésico não é, ao que indica Spitz, uma tarefa simples, uma vez que essa seria uma forma de percepção estranha e "há muito esquecida" por nós, adultos-padrão, e portanto muito diferente da experiência comum e imediata que temos do mundo por meio de nosso sistema sensorial. Isso se deveria, em grande parte, ao fato de funcionarmos sobremaneira segundo uma organização sensorial diacrítica. Dessa forma, definir o que seria essa "recepção cenestésica" é, em verdade, imaginar/supor um quadro a partir de paralelos e indícios derivados de situações e fenômenos diversos. Não nos estenderemos, devido aos objetivos desse trabalho, no relato destes últimos. O leitor que se interessar encontrará o material na íntegra no livro de referência. Para o momento, nos basta citar que Spitz procura retratar essa forma de percepção a partir: a. de relatos de cegos de nascença que, quando operados de suas cataratas congênitas, recuperaram a visão mas ainda assim não conseguiam "ver" os objetos, dar-lhes sentido e reconhecê-los. Muitos desses pacientes relatavam serem invadidos por sensações inespecíficas, confusas, totais, acachapantes. E alguns, em princípio, nem identificavam que elas vinham de seus olhos; b. de fenômenos regressivos nos adultos, como os estados de transição entre sono e vigília, bem como o efeito sobre a percepção provocado pela anestesia local em uma parte do corpo; c. de estudos neuroanatômicos e fisiológicos sobre o funcionamento dos órgãos de percepção de bebês e também de animais, dando destaque à primazia de regiões como a pele, a boca e o estômago.

Afirma, por esse caminho, que praticamente toda a percepção do recém-nascido "passa pelos sistemas interoceptivo e proprioceptivo; [e] as reações das crianças ocorrem a partir da percepção de necessidades comunicadas por esses sistemas" (Idem, p.36). Justifica-se falar, assim, em "mundo do bebê", isto porque os estímulos e perceptos gerados por esses dois sistemas (interoceptivo e proprioceptivo) e que constituem a maior da parte da experiência sensorial do recém-nascido seriam de uma ordem muito diversa dos que compõe o "mundo" dos adultos. Em outras palavras, os elementos que compõe as formas de percepção são tais como: ritmicidade, calor, toque, tato profundo, alterações de posição do corpo, sensações de 
Spitz deixa claro que o bebê conserva uma espécie de memória corporal, nesse sentido intero-proprioceptivo, das regularidades com que a mãe o pega no colo, balança, encosta no peito para mamar, do seu calor, das batidas do seu coração, do ritmo, do tom de voz... enfim, desse conjunto de experiência que poderiam compor um tipo de registro a partir dos sistemas de recepção cenestésica. Esses registros são fundamentais no primeiro ano de vida do bebê, quando ele pode, então, a partir deles, organizar uma percepção diacrítica, que envolve uma discriminação maior pela visão e pela audição (percepção à distância). Uma vez que tato (incluindo tato profundo), olfato, sensações vestibulares, etc. são as sensações básicas dos sistemas intero e proprioceptivos ${ }^{63}$. Assim, estes se tornam, por um lado, a base necessária para a percepção diacrítica, pela aproximação "captada pela visão" do alimento que chega, normalmente trazido pela mãe ou cuidadora e que "resolve" a tensão interna provocada pela fome no corpo. E, por outro, se tornaram a base da comunicação que passará a envolver a discriminação perceptiva.

Façamos um pequeno parênteses no discurso dessa aula. Para Spitz, em linhas gerais, se poderia dizer que ao longo do primeiro ano ocorrem transformações radicais de diversas ordens (motoras, neurológicas, psíquicas, afetivas e perceptuais) que levam o bebê de um estado de indiscriminação e desamparo ao desenvolvimento de recursos e mecanismos que lhe permitem algum domínio (atividade), reconhecimento

desconforto ou satisfação de um modo geral (muito ligadas à homeostase do organismo e ao sistema interoceptivo), entre outras. Assim, afirma Spitz, que a percepção do bebê é de certa forma caótica e indiferenciada e que ele reage principalmente a esses estímulos que "vem de dentro do corpo" (intero e proprioceptivos).

${ }^{63}$ Diz Spitz: “As sensações do sistema cenestésico [recepção cenestésica] são extensivas e em grande parte viscerais; seus órgãos efetores são, basicamente, a musculatura lisa; sua organização nervosa compreende, entre outros, os sistemas simpático e parassimpático. As sensações do sistema diacrítico são intensivas e envolvem os órgãos sensoriais; sua musculatura é estriada e sua organização nervosa é subordinada ao sistema nervoso central." (grifo nosso, Spitz, 1965/2004, p. 74) 
(discriminação) e adaptação relativos ao "mundo externo". Em termos psicanalíticos, isso significa que ao nascer o bebê não teria Ego (e, portanto, nenhum de seus mecanismos psíquicos está desenvolvido, como consciência, percepção, memória, linguagem) e que seria ao longo do primeiro ano de vida, pelo progressivo desdobramento das relações objetais, que o Ego se constituiria (Spitz R. A., 1965/2004, p. 4). De tal forma que, nesse período, a criança transitaria do "fisiológico para o psicológico e social" (Spitz R. A., 1965/2004, p. 12). Está aí, na possibilidade de transitar do orgânico para o psicológicosocial, o ponto nodal dos pressupostos e estudos de Spitz, de que o desenvolvimento psicológico na primeira infância (independentemente de que esfera se tratar) se dá por meio e a partir das relações e trocas mútuas no interior da díade mãe e bebê, num clima afetivo favorável (com caráter prazeroso). Voltemos às palavras de Guirado.

É daí, da produção e conservação desses registros, que ocorre a evolução para a apercepção ${ }^{64}$ característica da angústia dos oito meses, em que se mostra a memória do objeto, já objeto da libido. Nesse momento, o vínculo afetivo com a mãe assume as características de um objeto presente no afeto e na memória, e que vai fazer evoluir a função egóica da comunicação para além da expressividade da Anlage, que por sua vez é característica biológica da espécie. Ou seja, quando a criança chora a ausência da mãe, na presença de um estranho, ela teria constituído, na singularidade que lhe torna característico, o objeto da libido, marcado e reclamado por sua memória.

64 “Quando um estranho se aproxima do bebê de oito meses, este fica frustrado em seu desejo de ter a mãe. A ansiedade que demonstra não é uma resposta à memória de uma experiência desagradável com um estranho; é uma resposta à sua percepção de que o rosto do estranho não é idêntico aos traços de memória do rosto da mãe. Isto ilustra a operação de apercepção; nesta operação um percepto no presente é comparado com traços de memória do passado.” (Spitz R. A., 1965/2004, pp. 156-157) 
Nisso tudo, considerando-se que fica aberta a possibilidade da comunicação por sinais intencionais na relação mãe-filho, não se perde por completo a comunicação expressiva $^{65}$. A linguagem incluindo a palavra pode obscurecer, mas não eliminar a expressividade como comunicação. Ela ressurge com mais força em momentos e em algumas pessoas ao longo da vida. Há pessoas que preservam a comunicação expressiva, segundo Spitz, são alguns artistas, a título de exemplo, os circenses no trapézio, nas apresentações de equilibristas, etc. Por outro lado, todos nós, em fases e momentos específicos de nossas vidas, podemos retomar as formas de comunicação expressiva. A maternidade, por exemplo, para mulheres é ocasião disso.

Se entendemos o Bloco Mágico, com Freud, como memória inconsciente que parte do aparelho perceptivo consciente até a constituição de uma rede de sentidos organizada no plano inconsciente ${ }^{66}$, podemos estender essa compreensão para a comunicação expressiva do início da vida. Mesmo que independa da consciência e da intencionalidade do "feito" comunicativo, ela guarda essa função de origem de toda e qualquer comunicação, datada do início da vida e exercida na díade mãe-filho. Mesmo os registros que não passem inicialmente pela palavra, são experiências de um corpo em

\footnotetext{
65 Nos termos de Spitz (Spitz R. A., 1965/2004), a comunicação por sinais é um tipo de linguagem alocêntrica, em oposição à comunicação expressiva, que é uma linguagem egocêntrica. Esta se refere ao fato de ser centrada no sujeito, ou seja, ela é a expressão de um estado ou processo interior e não se destina a ninguém. É assim que pensa, analogamente, as vocalizações do bebê recém-nascido, sem uma mensagem destinada volitivamente/intencionalmente a um interlocutor. Em contrapartida, boa parte da comunicação adulta, tem características alocêntricas, pois compõe-se de uma mensagem dirigida intencionalmente a uma outra pessoa.

${ }^{66}$ Um desenvolvimento conceitual a respeito do inconsciente do Bloco Mágico como memória foi trabalhada na primeira parte deste trabalho no Capítulo 1. Sobre este trabalho: história e método.
} 
relação ao outro (mãe e filho) fundamentais para a possibilidade de comunicação intencional posterior, a dos sinais apreendidos e emitidos volitivamente pelos parceiros.

Daniel preserva essas formas de comunicação expressiva, como já se poderia depreender do que dissemos até agora. Mas isso acontece em um menino de onze anos, de quem é exigida uma comunicação por sinais, para demandar do outro o que deseja ou precisa. É, então, de se esperar que ele se "atrapalhe" entre seu modo de se comunicar e as exigências do mundo a que ele deveria estar respondendo.

O que se tem notado é que ele consegue, com algumas pessoas e figuras que garantem a ele a regularidade, a constância e a presença, uma comunicação que admite o gesto compreendido no outro e que recebe dele respostas de prazer e desprazer, às vezes conforto e desconforto. A expressividade é marca dominante dessa sua comunicação!

Não é brilhante a tessitura que Guirado estabelece entre comunicação expressiva, memória e os sentidos desse e para esse corpo chamado Daniel? Com essas suas palavras, nos autorizamos a voltar a tratar da vida de nosso grande garoto.

Daniel ainda é, como já foi dito, na idade de onze anos, muito sensível a desequilíbrios de ordem "fisiológica". Os desconfortos físicos (dores de cabeça, de barriga, câimbras nas pernas, no corpo todo, etc.), quando presentes, alteram radicalmente sua condição de "estar no mundo". Ou seja, suas formas de contato, suas ações e atitudes se modificam, em geral perdendo em complexidade e plasticidade, quando se lhe apresenta algum mal-estar corporal. Dores de barriga e constipação são exemplares disso, aumentam sua agitação geral, dando um caráter ansiógeno aos seus movimentos, algo 
tenso e ininterrupto; se torna incapaz de permanecer na mesma posição, sua ponta de pé assume o ápice de elevação e sua expressão facial assume certo ar de compenetração ${ }^{67}$. Esses podem ser considerados os sinais de uma comunicação expressiva, sem intencionalidade ou consciência.

Nesse sentido, é como se Daniel o tempo todo estivesse numa espécie de negociação entre o que o atinge por "dentro" e o que o atinge de "fora", de tal modo que “descompensações" internas, por vezes, podem tomar todo o foco de suas atenções e ações. Uma simples dor de barriga, muitas vezes, inviabiliza que ele estabeleça contatos e se coloque frente às pessoas, objetos e situações do modo a que está habituado. Segundo estudos da etologia, citados por Spitz (Spitz R. A., 1965/2004), bebês famintos, podem não "reconhecer" o bico do seio e demorar a mamar, tal o grau de tensão a que chegam por seu desconforto interno.

Daniel não é um bebê, no entanto, carrega certa semelhança em seus modos de ser e de se comunicar. Suas expressões, de toda ordem, se alteram em função de seus estados (de cansaço, de fome, de alegria, de contrariedade). Como quando o levei para almoçar na casa de uma amiga sua, que não o via há meses. Nesse dia, sofremos mais de hora parados no trânsito, enfrentando o calor e a fome que já se anunciava. Quando chegamos ao apartamento, Daniel foi recebido de braços abertos e sorriso largo pela amiga, que dizia da sua saudade. Ele a olhou significativamente, mostrando que a reconhecia, mas o resto de seu corpo estava tomado pelo desconforto causado pelo calor e a fome, de modo

${ }^{67}$ A constatação dessas relações entre as dores de barriga e seus efeitos "visíveis"/observáveis não foi pontual, ao contrário, temos registros de frequência quinzenal de sua ocorrência ao longo destes últimos cinco anos. 
que havia certo descompasso entre o olhar satisfeito e significativo dirigido a ela e o corpo tenso e agitado que adentrou o recinto. Eu o levei até a cozinha e, todos, nos alimentamos. Depois, já mais satisfeito, Daniel se acalmou um pouco e passou a admirar as pessoas que estavam sentadas à mesa. Fomos lhe explicando e retornando à memória quem eram e o que ele fazia lá; tinha ido para ver a amiga, que tanto gostava dele. Logo segurou o colar que ela usava, como costumava fazer, intercalando olhares entre a bijuteria e ela; enfim, parecia que seu corpo estava novamente disponível e em seu controle, para responder à suas memórias e expectativas, e não apenas às suas "necessidades básicas".

Entre todas as investidas desse trabalho, essa no domínio daquilo que amplamente se chama comunicação foi, sem dúvida, a mais delicada e complexa. Isso porque, se podemos pensar as formas de contato e relação do Daniel nos limites das possibilidades da concretude de seu corpo e de seu movimento, coloca-se a pergunta: que comunicação, então?

Essa pergunta funciona como uma cobertura para ramificações várias, exigidas pela singularidade desse caso. A primeira que abordaremos é mais concreta e, por isso, o carro-chefe: que comunicação é possível para o Daniel? Uma vez que, quando o conheci (contava então com seis anos de idade), encontrava-se em uma condição de quase incomunicabilidade... Não que seu corpo e expressões não dessem sinais de seu estado geral, que poderiam ser "lidos” por um observador atento e sensível. Mas ele (o Daniel) é que não comunicava intencionalmente praticamente nada do que queria, sentia, pensava... O que não implica que não quisesse, sentisse ou pensasse algo. Mas o que 
dizia dele era, mormente, alguns sinais expressivos ${ }^{68}$, que têm a característica de serem quase involuntários e genéricos, concernentes a emoções, estados afetivos e/ou sensações experimentadas no próprio corpo. Assim, Daniel não comunicava que estava com fome, por exemplo, seu semblante é que se alterava, denotando claro desconforto. Se a necessidade não fosse saciada, ele explodia em choro inconsolável. Dessa maneira, ficava a cargo das pessoas ao redor dele "decifrarem" esses índices nebulosos e genéricos, para suprir, com sorte, alguma necessidade sua; dar uma resposta a um pedido nunca formulado. Em resumo, na idade que o conhecemos, Daniel não apresentava um meio de se comunicar, também não parecia ter "vontade" de fazê-lo e provavelmente ignorasse a possibilidade de ter, em outra pessoa, um interlocutor.

Seguem dois exemplos de situações que ilustram esse modo de (in)comunicabilidade dos inícios do acompanhamento de Daniel.

Situação 1:

Daniel está eufórico, mais tenso e intenso que o normal. Ainda que aparentemente feliz, corre de um lado para o outro, alheio ao redor. Bate fortes palmas, que certamente devem machucá-lo, pois o som dos estalos faz doer nossos ouvidos. Tento contê-lo, abraçá-lo. Em vão... Seus músculos estão rígidos e ele pula freneticamente entre meus braços, incapaz de se deixar

\footnotetext{
${ }^{68}$ Para retoma aqui um dos conceitos de Spitz, tal como organizado por Guirado. Nesse caso não há uma mensagem que é dirigida intencionalmente a outrem. Na comunicação expressiva, as ideias de interlocutor, de intencionalidade e de mensagem estão ausentes do ponto de vista do sujeito da ação.
} 
acolher. A boca cerrada e o cenho franzido expressam imensa concentração, mas em algo que só pode ser interno (do corpo? Da mente?..). Ele força ainda mais sua ponta de pé, esticando ao máximo seu corpo para cima. A certo tempo, apoia as mãos na mesa e o corpo assume uma postura singular, como se estivesse sobre uma bicicleta. A agitação dá lugar a um estancamento rígido... Encaminho-o apressadamente ao banheiro, onde ele, prontamente, faz cocô. Sua expressão desanuvia e volta a sorrir com um pouco de prazer.

Situação 2:

Ao chegar à escola é levado, por sua tutora, para a sala de aula. Se dirige a algumas cadeiras e as gira, habilmente apoiandoas sobre uma de suas pernas (da cadeira). É colocado sentado. Mas não consegue parar, pelo contrário, dá sinais de ansiedade, e há um aumento claro de sua agitação. Enfim levanta. Corre para fora da sala. Em seguida é trazido de volta, mas ele está diferente, seus movimentos estão mais rápidos e frenéticos. Tenta correr novamente para fora da sala, mas é bloqueado. Não reage ao impedimento, apenas muda a rota de sua corrida, que está ainda mais veloz. Suas mãos, num ritmo alucinante, agarram e soltam objetos que encontram pela frente, lápis, canetas, cadernos...mas ele mesmo não parece se dar conta disso. Os sinais de ansiedade agora são inegáveis. E Daniel age como um passarinho que acabou de ser preso numa gaiola, sem raiva, apenas se debate e bate entre uma e outra grade. Saímos da sala para um espaço mais amplo, o pátio da escola, e ele corre rapidamente, como numa explosão de energia. Depois, destensiona e retoma certo nível de relaxamento (que nunca é pleno, em seu caso). 
É de destaque nesses exemplos a importância que assume quem o observa no destino que será dado a esse desconforto, que só parece aumentar. Um desconforto que é, no início e no fim, físico, corporal, descrito como tensão, rigidez, intensidade, velocidade; atributos de seus músculos, suas mãos, seus pés, seu rosto e seus movimentos. E nisso tudo, um Daniel que parece não se "dar conta" do que sente e faz... parece tão só sentir e fazer. Nesses exemplos, seu corpo é o mandante, o sujeito dos verbos nas orações que construímos. Quem observa é então também quem lê em suas ações, em seus movimentos, em seu estado geral, sinais de que algo está acontecendo... Sinais, nesses casos, de tensão, aos quais atribuímos o sentido de desconforto, desagrado, desprazer. E esse talvez seja o aspecto definidor de situações como essas: Daniel parece impossibilitado de atribuir sentido àquilo que sente, e impossibilitado também de fazer qualquer ação que seja mais efetiva para alterar seu estado geral para um mais confortável... É o observador que atribui esses sentidos para aquilo que faz - "vontade de ir ao banheiro"; "sentir-se preso na sala de aula" - e lhe oferece o destino adequado (direcioná-lo ao banheiro ou correr no pátio).

Nesse caso, o que podemos chamar de "comunicação" é mais uma construção de um dos parceiros de cena a partir dos indícios expressivos dados pelo outro... que pode observar e atribuir sentido aos movimentos um tanto erráticos e pouco claros, mas nem por isso menos significativos.

Nas ações de Daniel, um olhar sequer, dava sinal de que ele percebia o que estava acontecendo consigo, também não procurava, em qualquer pessoa, algum tipo de ajuda... Ele, mais do que ninguém, estava à mercê de seu corpo. 
Assim, em situações como essas, positivava-se essa corporeidade eloquente do Daniel... embora alheia a ele mesmo.

Foi nesse "quadro" que o encontramos em 2014. Um corpo que dava sinais evidentes de que algo acontece, mas que nunca dirigia esse sinal a um interlocutor; um corpo que pedia ajuda sem pedir.

O leitor atento notou que, ao tratarmos dessa incomunicabilidade, conjugamos os verbos no passado. Pois bem, de fato temos um antes e depois nessa história. Mas o momento inicial dessas formas de expressão genéricas e totais não cedeu completamente seu lugar para uma comunicação relativamente clara, direta e inequívoca. Mais certo seria dizer que, nesse intervalo de alguns anos, se mesclaram em seu corpo, em seu movimento, por seu corpo, por seus movimentos, sentidos possíveis, construídos em contextos possíveis nas relações concretas que estabelecia. Produzindo formas bastante singulares de dizer de si.

A descrição analítica desses tempos é que responderá à pergunta "que comunicação é possível para o Daniel?”, que abordaremos no tópico seguinte. Uma ressalva final: a expressão possível para o Daniel, não foi utilizada no sentido mais comum, referente às capacidades (comunicacionais, mentais, cognitivas, etc.) de nosso garoto. Antes disso, refere-se à constelação sui generis de fatores para a configuração deste quadro. O possível está no campo do contexto, do acaso e do discurso, como diria Guirado, e não no binômio capacidade-incapacidade do Daniel. 
Cenas e discursos: os caminhos dos afetos, das memórias, da singularidade

Esse item se compõe de múltiplas e variadas cenas, análises e considerações. Com ele se pretende desenhar os diferentes modos pelos quais Daniel exerce lugares de enunciação, as diversas nuances que seu corpo e seu movimento assumem, tecendo seus afetos, suas intenções, suas memórias... Tudo isso, para configurar os sentidos que se produzem por e nessa singularidade marcadamente Daniel.

Retomamos assim a Tese dessa pesquisa, anunciada muitas páginas atrás:

Daniel também faz registros, deles compõe memórias em rede, que carreia, como "expectativa", nas novas relações que estabelece vida a fora. Ele também traz consigo a memória marcada das relações que viveu e vive; é o bloco mágico do Daniel. Por isso, apostamos que, além de nós, ele também preserva uma história de si. Sem palavras como as nossas, que possa nos falar...

É sobre essa "aposta" que o presente trabalho se estrutura como o desafio de uma análise institucional do discurso do Daniel; uma analítica da subjetividade." (ver p. 36)

Retomemos também o ponto em que deixamos a discussão no item anterior: entre a comunicação expressiva estendida e as solicitações sociais para alguém de sua idade, Daniel assenta-se sobre tensão constante para se posicionar no mundo. 
Corpo e discurso: alçando algumas soluções de sentido (título provisório)

Nesses anos que acompanho Daniel, pudemos viabilizar novas formas de comunicação, sempre numa negociação tensa e delicada entre a singular expressividade que lhe é característica e as necessidades de contexto. Algumas se mantém até hoje, ao que discorreremos em breve, com o objetivo de desenhar (analiticamente) os modos como Daniel "diz" do que quer, pode ou precisa dizer. Não é nossa intenção, por outro lado, discutir os pormenores das estratégias e dos métodos utilizados no trabalho concreto que fizemos ao lado dele. Antes, nos interessa a singular apropriação que ele pôde fazer desses instrumentos, bem como os sentidos que foram possíveis produzir a partir daí. E já adianto que, de certa forma, não fui eu que escolhi ensiná-lo o método $\mathrm{A}$ ou o método $\mathrm{B}$ de comunicação (alternativa ${ }^{69}$ ), mas a situação concreta, o contexto e o próprio Daniel foram trilhando um caminho ou outro; de tal forma que foi possível manter alguns recursos e outros simplesmente deixar de lado. Portanto, não vamos levantar nenhuma bandeira em defesa de outra coisa que não a da urgência, da possibilidade e da competência de Daniel se comunicar, da forma que for lhe possível.

${ }^{69}$ Por exemplo: sistema de troca de figuras ou gestos motores, ou recursos de informática, e tantos outras formas de comunicação suplementar e alternativa. 
No contexto da escola em que o acompanhávamos, uma situação concreta em especial "solicitava", por assim dizer, algum "signo" de comunicação, embora ela não fosse ocasião de produção de desconforto para ele, em princípio. Tratava-se do momento da hora do lanche. Como já dissemos, Daniel costumava pegar, sem permissão, o lanche das outras crianças. O que era muita vez constrangedor, embora ele mesmo não indicasse ter ciência dos efeitos dessa sua ação, até do mais imediato deles, o afastamento das crianças, que receavam perder seu alimento para aquele menino "grandão".

Há, na ação do Daniel, alguns elementos que podemos destacar para melhor caracterizar essa situação. O primeiro é da ordem das imagens e das expectativas que se formavam para as crianças sobre o Daniel. Pois os alimentos que ele pegava eram sempre aqueles mais saborosos (coxinhas, salsichas, balas, refrigerantes, etc.) - talvez por isso mesmo é que os pegasse. No entanto, assim como ele, as crianças que os levavam ou adquiriam na cantina também os preferiam por esse motivo... Isso aumentava a tensão provocada pela ação do Daniel, que era avaliada como muito danosa pelas crianças, sobretudo as menores, ao se verem sem suas guloseimas.

Em segundo lugar, era curioso que, numa situação inversa, quando alguma criança pegava uma bala sua, por exemplo, ele não demonstrasse qualquer tipo de contrariedade ou simplesmente uma reação. Se de um lado tínhamos as expectativas e imagens que as crianças formavam sobre ele, o "pegador de lanches"; do lado do Daniel, suas ações não denunciavam que reconhecesse ou sequer conhecesse essa sua imagem. Talvez, inclusive, isso a que chamamos de expectativa e imagem de si e do outro, bem como a imagem do outro sobre si, sejam elementos alheios ao Daniel, distante demais para organizarem, por assim dizer, suas ações. Por tudo isso, é possível supor que para ele os pronomes próprios e possessivos parecem não ter registro na experiência. A ideia de que aquele lanche é dele 
e não de um outro, ou de que é do outro e não dele, parecem não compor as ações do Daniel. Em resumo, supomos que lhe faltassem todas essas noções que ligam a coisa a seu dono - "meu”, "seu”, "nosso".

Em terceiro lugar, Daniel avistava à distância seus alimentos de preferência e mudava a rota de seu caminhar em direção a eles. Poucos objetos ou pessoas chamavam tanto sua atenção e o faziam agir desse modo certeiro e intencional.

Por fim, mesmo com essa sensibilidade para perceber e essa prontidão para agir de forma a conseguir suas guloseimas, Daniel não teimava obstinadamente quando, por qualquer motivo, não as conseguia. Muitas vezes era impedido por algum adulto ao esticar a mão para arrancar o pedaço de algum lanche, e não dava sinais de frustração ou de chateação. Com naturalidade seguia andando ou fazendo o que estivesse fazendo momentos antes. E quando aparecesse novamente em seu radar um alimento saboroso, ele faria exatamente a mesma coisa: tentaria pegar um pedaço.

Por tudo isso, temos que: socialmente, a atitude do Daniel é prejudicial. Afasta os colegas e, por ser inadequada às regras pactuadas no cotiadiano, pode ser considerada "mal-educada" (por alguns moralistas....). Para ele, no entanto, não é possível aplicar o mesmo crivo. Pois o "social" é uma paisagem que o universo de suas sensorialidades, necessidades e prazeres não lhe permite contemplar. Pegar, e só, é uma ação que lhe é possível executar para atingir seus fins, talvez a única. Sem poder falar, sem poder dizer de alguma outra forma e, ainda, sem ter alguém que se coloque como seu interlocutor, e que atentamente possa mediar a transição de suas vontades em realizações.... Ora, quem não pegaria?

Escolhemos essa situação para o aprendizado porque, diferentemente das que narramos acima, ela envolve algum prazer, e não desconforto, tornando-a auspiciosa para 
nosso fim: no plano imediato, ensiná-lo a esticar a mão aberta para pedir o lanche das crianças. Num plano mais geral, ensiná-lo a se comunicar por meio de um sinal na forma de um gesto motor. ${ }^{70}$

Experiências passadas vieram a nosso socorro. Luisa Guirado, a psicóloga que o acompanhava antes de nós, relatou ter lhe ensinado a "chamar as crianças batendo em seus ombros e em seguida esticar a mão aberta, espalmada para cima, para pedir um pedaço"; como se vê, desde seus três anos, pelo menos, ele "pega" a comida alheia. Disse, inclusive, que ele fazia com regularidade isso e que demonstrava entender seu sentido.

Assim, retomamos, na nova situação, o gesto... que se mostrava promissor, o de espalmar sua mão em direção àquilo que deseja (o chamaremos, doravante, para facilitar a leitura de "gesto de pedido"). De fato, ele tinha a lembrança motora e o realizava com certa facilidade. Mas, passados alguns anos, escapava-lhe o sentido. Ele o fazia apenas se solicitado e, mais ainda, se lhe fosse impedido o acesso ao que queria. Era necessário um comando externo e/ou uma barreira concreta para ele, só aí, recorrer ao sinal que, não obstante, conhecia. É que, ao que parece, ele não o reconhecia...

Ainda que aparentemente sem sentido para ele, repetimos insistentemente situações diversas que o instigassem a usar o gesto de pedido, procurando modos de viabilizar seu aprendizado ou, no mínimo, seu uso. Para isso, por exemplo, retínhamos

\footnotetext{
${ }^{70}$ Poder-se-ia questionar por que este era o objetivo e não outro como, por exemplo, ensinar as noções de o que é próprio ("meu") e de o que é do outro; ou mesmo uma ideia de proibição ("não pode pegar") como regra social. Pelas observações que expusemos é lícito supor, no entanto, que essas outras possibilidades não contemplavam as condições do Daniel naquele momento de sua vida. Dessas condições falamos no início deste trabalho no capítulo "Daniel: uma descrição exemplar". Para as retomar de modo sintético: de um lado, não existia um lugar de enunciação previsto para o Daniel, ele estava de fato à margem do discurso, das instituições e das relações que o cercavam; de outro, ele mesmo ainda tinha exclusivamente no próprio corpo a referência e o sensor de suas ações no mundo.
} 
em nossas mãos seu lanche e ficávamos "distraídos”, como ele não conseguia pegar, em pouco tempo passou a usar o gesto conosco. Depois expandimos, com a contribuição das crianças e das professoras, que faziam "exercícios" semelhantes com ele. Trocamos também os alimentos por outros objetos e repetimos, sempre que possível, diversas situações que exigissem esse sinal de comunicação. Por tudo isso e por sua capacidade, Daniel (re)aprendeu a utilizar o gesto. Mas esse não foi todo o processo... Observamos, durante a gestação desse aprendizado, uma mudança de carácter mais geral em sua postura e em suas condições de relação com o mundo e com os outros. O gesto sem sentido, repetido maquinalmente em situações forjadas de aprendizado, disparou e abriu o discurso e as possibilidades de ação e produção de sentidos pelo e com Daniel. Vejamos como...

Em pouco tempo, Daniel entendeu que, para conseguir aquilo que estava em posse de outra pessoa, ele precisava fazer aquele gesto de pedido. Muitas vezes, no entanto, até que chegássemos a essa prontidão da ação, foi necessário oferecer um suporte físico ao movimento do Daniel, a saber: acontecia de ele repetir a tentativa de pegar algo e não se "lembrar" de fazer o gesto, nesses casos, demonstrávamos para ele como deveria agir e, como lhe era difícil reproduzir apenas olhando, lhe dávamos um suporte físico, conduzindo sua mão à posição esperada. A nossa expectativa é que ele passasse, por si, a usar o gesto de pedido em situações similares sem o escoramento fornecido no processo de aprendizagem.

Observamos, no entanto, que Daniel se apropriou não só do gesto que ele fazia, mas também do gesto que o seu interlocutor realizava. De tal forma que, antes de esticar 
a sua mão, ele conduzia a mão do outro à posição espalmada e aí colocava a sua por cima. Estava feito, a seu modo, o pedido.

Interessa-nos destacar, para os fins deste trabalho, que muito mais importante do que um pedido, foi o sentido do gesto, denunciando a expetativa do Daniel em relação ao seu parceiro de cena. Este deveria, segundo o que lembrava, também esticar sua mão; era uma ação que ele esperava que o outro realizasse. Por isso, antes de esticar sua mão, gentilmente posicionava a mão de seu interlocutor na posição costumeira que suportaria a sua. Na relação que estabelecia com os outros nessas situações, sua ação se voltava sobre a ação do outro, de acordo com a expectativa que carreava de sua memória para a situação presente. Exploraremos essas considerações um pouco mais à frente, neste capítulo. Por ora, seguiremos com o relato de outros desenvolvimentos no domínio da comunicação.

No âmbito dos gestos motores, desenhamos um "plano de ensino" de mais alguns sinais de comunicação. Foram eles: apontar, "não" e "comer”. Por características próprias ao modo de aprendizado do Daniel, a ajuda física foi nosso principal instrumento para viabilizar que ele executasse os gestos. No caso do apontar, segurávamos sua mão em direção àquilo que desejava (mormente, algumas guloseimas da cantina que estavam a uma altura que ele não alcançava) e o auxiliávamos a fechar a mão e esticar o indicador. Conforme sua ação tornava-se mais clara e autônoma em relação ao nosso apoio físico, retirávamos esse. Com alguns dias de prática, Daniel passou a fazer o gesto de forma relativamente clara. Um detalhe importante é que ele só o fazia quando da presença de um adulto que estivesse com ele, lhe dando atenção. Este era o contexto no qual, para ele, o gesto tinha lugar e sentido, a saber, a atenção dispensada por um interlocutor qualificado. 
O gesto de comer se tratava de apontar, com o dedo indicador, a própria boca; seu significado seria "quero comer", segundo, mais uma vez, a nossa expectativa/planejamento. Como o de apontar já estava estabelecido quando iniciamos esse outro aprendizado, o processo de ensino foi mais rápido, bem como a apropriação de um sentido pelo Daniel. Assim, quando ele via algo que desejava comer, ele apontava, ao que oferecíamos o auxílio físico levando sua mão em direção à própria boca. Rapidamente esse apoio físico pôde ser retirado e substituído por um visual, nós é que realizávamos o gesto ao que Daniel repetia/imitava. Tendo sido motoramente estabelecido, ampliamos seu uso para situações em que a comida não estava sensorialmente presente (ao alcance de suas mãos, olhos, paladar e olfato). Assim, fazíamos ou solicitávamos que ele realizasse o gesto instantes antes de pegarmos sua lancheira para descer para o intervalo, por exemplo. Da mesma forma em todas as outras situações previstas de alimentação; preferencialmente sem a presença do alimento. De forma a que ele pudesse entender que o gesto valia para comunicar que ele "quer comer", independentemente de haver ou não algum alimento diretamente à sua disposição. Mesmo depois de saber o gesto, raramente Daniel o usava de forma absolutamente espontânea, por exemplo, dirigindo-se a alguém e sinalizando. Na maioria das vezes, ele usava para responder alguma pergunta direcionada a ele: “onde você está indo, Daniel?"; “O que você quer?”. Assim, cabia a seu interlocutor iniciar a comunicação, ao que ele respondia com o gesto que sabia e fazia sentido naquele contexto. 
Por fim, também trabalhamos o gesto de "não" com a cabeça. Linguisticamente, talvez fosse o mais complexo, pois o "não" é um conceito ${ }^{71}$, não representa nada especificamente; é uma negativa apenas. Por outro lado, no conjunto das situações de vida do Daniel, muitas vezes suas ações denunciavam uma espécie de negativa, recusa, de tal forma que nelas o "não" teria um sentido menos abstrato, mais apegado ao contexto. Quanto a isso, podemos destacar que ele, no momento de subir para a sala de aula, "estancava" na escada, chegava a sentar nos degraus e olhar vagamente para a frente, como quem pudesse (desejasse) passar desapercebido. Também, alguns objetos, por suas características sensoriais, eram aversivos a ele, principalmente aqueles mais ásperos, como lixas, e Daniel os afastava prontamente quando lhe eram apresentados. Por fim, alguns itens de alimentação, inclusive água, eram rejeitados por ele, que os empurrava ou virava seu rosto. Foram essas situações aproveitadas, então, como ocasião de ensino: ao se apresentar a situação ou objeto alvo de sua "esquiva", verbalizávamos "Ah, você não quer...” ou “não?!" ao mesmo tempo em que realizávamos o gesto de balançar a cabeça e o auxiliávamos a fazer o mesmo. Assim se seguiu até que ele utilizasse e se apropriasse desse sinal.

De posse desse conjunto restrito, mas crucial, de sinais de comunicação, Daniel estabeleceu comigo sua primeira conversa. Contava oito anos, estávamos em sala de aula, tendo há pouco retornado de uma atividade lúdica no espaço externo, quando lhe solicitei que sentasse para "trabalharmos um pouco". Tendo realizado apenas metade da atividade, um jogo de montar peças, Daniel parou. Ao que lhe disse "vamos lá, Dani, está

\footnotetext{
${ }^{71}$ Ver O primeiro ano de vida (Spitz R. A., 1965/2004) e O não e o sim (Spitz R. , 1957/1978).
} 
faltando...", mal pude finalizar a sentença e sua cabeça já se movia eloquentemente de um lado para outro, seus olhos me encaravam expressivamente asseverando o que sua boca não podia dizer. “Ah...não, né...então o que você quer, Daniel” perguntei. Apontou para sua própria boca - "Comer! Você quer comer?! Pode pegar a lancheira. Vamos lá". Descemos, em silêncio, para o refeitório, porque tudo já estava dito...

Mais sobre comunicação: sentidos nas palavras de um outro

Este item é dedicado à análise e discussão das situações apresentadas acima. Nesse sentido, uma mudança dos registros pelos quais pensamos e entendemos usualmente o que é comunicar-se será necessária, uma vez que, no caso do menino Daniel, a comunicação intencional foi uma construção diária e não uma habilidade que surgiu natural e espontaneamente, como para a maioria de nós. É preciso lembrar aqui da completa incomunicabilidade intencional desse menino e dos modos unicamente expressivos que de suas manifestações (como descrevemos à altura da p. 130). O que provocou que o trabalho sobre comunicação, além de urgente, devesse se construir apoiada justamente nesses elementos de expressividade que não dependem da intencionalidade de quem os "emite". Ou seja, mais do que ensinar alguém o uso de alguns gestos, placas ou palavras, se tratava de desenhar os caminhos pelos quais ele poderia reconhecer que é possível "dizer" de algum modo alguma coisa. Que ele, o Daniel, poderia com o mínimo de intencionalidade dirigir algum signo, sinal, gesto, expressão para uma outra pessoa. Tratava-se de estabelecer as bases de uma comunicabilidade possível. Por isso, no plano imediato de seu acompanhamento, foi preciso emprestar sentidos às ações e atitudes que fazia ou aos estados em que se 
encontrava; foi preciso considerar como atos de comunicação elementos que corriqueiramente não se prestam a isso; e devolvê-los a Daniel como uma narrativa dele para ele mesmo. Por fim, foi preciso tomar o não dito como um elemento do discurso de Daniel, para que assim pudéssemos estabelecer um terreno possível de interlocução, ainda que para isso fosse necessário que atribuíssemos sentido, significado e intencionalidade a comportamentos aparentemente sem interesse comunicativo.

Assim, de partida, o contexto, como condição de possibilidade de comunicação, seria produzido e instaurado pela perspectiva de quem se relaciona com o Daniel. Pois este, por si, não parecia “tentar" dizer, "querer" dizer ou mesmo reconhecer que se pode "dizer". O outro é que "ouve" um "dizer" onde, a depender unicamente do Daniel, pode não existir.

Ouvir e acompanhar um discurso, mesmo em situações em que não há fala, é a condição básica do exercício desse acompanhamento - por decorrência, também do trabalho acadêmico. É, em verdade, o efeito concreto imediato de uma análise exercida como uma analítica da subjetividade. Isso porque a AID parte de uma tese fundamental, a saber:

Ao considerar uma respeitável maioria dos pequenos de dois ou três anos de idade, pode-se dizer que seu acolhimento em um ambiente em que o brincar, acompanhado de um adulto atento a seus movimentos, estancamentos, direções de olhar, ocupação do espaço e uso de materiais, será a ocasião de se colocarem em posições sugestivas do interesse e da demanda que apresentam para nosso trabalho. Um modo de discursar sem palavras, em ato, literalmente dispondo-se em cena a partir de lugares com mobilidade maior ou menor, diante de seu assim instituído interlocutor. Este, sim, pode falar-lhe com palavras se essa regra 
também se instituir para o conforto e o andamento produtivo do trabalho dos parceiros de enunciação, de jogo, de cena. As condições para o reconhecimento e a legitimidade da relação que se criam estão dadas, são as balizas do "contrato" terapêutico estabelecido na e pela relação concreta entre o terapeuta e seu pequeno cliente, com a participação de ambos na determinação de lugares e pautas de conduta.

[...]Ainda, do lado da criança-paciente, não se pode duvidar: o matiz afetivo dá o tom de como cada uma exerce seu lugar no discurso da(s) sessão(ões). Os mais ruidosos em seu silêncio, os mais entristecidos e/ou agressivos pelo olhar e pelo gesto, os mais indiferentes ao contato, os mais isolados, os que convidam para o brinquedo puxando pela mão, os que se aninham no colo e nos braços do terapeuta, fazendo do corpo deste uma extensão do seu e de suas direções, de suas demandas e orientações e (por que não?) de seu desejo, e assim por diante: são todos personagens que com maior ou menor controle do movimento e da atenção, ou com maior ou menor consciência da funcionalidade de sua comunicação, seguem dizendo, seguem discursando em ato e afetos. A sessão assume caráter de acontecimento, de acaso, no interior da instituição terapêutica.

Pensar assim uma sessão é confrontar uma dimensão dessas práticas, a dos procedimentos e falas regulados pelo que pode ser dito, quem pode dizer, como pode dizer, como qualquer ordenamento de discurso (Foucault, 1970/1996). É confrontar regramentos e controles que excluem ora certas possibilidades de dizer, ora certos sujeitos de enunciação, ora certos conteúdos que por ventura e acaso poderiam ser ditos.

Pensar assim uma sessão é fazê-la com uma disposição analítica que, em ato, suspende os lugares canônicos que tornam os rituais, quaisquer que sejam, disciplinas sagradas para a consecução de efeitos. (Guirado M. , 2018, p. 137) 
Embora tenha recebido uma atenção especial nesse texto de 2018, essa disposição analítica (e ética) é marca que atravessa, do início ao fim, o corpo da $\operatorname{AID}^{72}$. Se a retomamos aqui, é para poder avançar em outra direção. Agora, a do plano concreto dos efeitos de assim instrumentar nosso pensamento. Nesse caso, a conduta do adulto no contato direto com a criança. Tivemos o privilégio de presenciar alguns encontros entre Daniel e Marlene Guirado (nossa orientadora, supervisora e autora de referência). De um lado, esse menino de corporeidade eloquente, mas que não fala, de outro, essa analista de discurso. Desses encontros, muitas cenas poderíamos descrever, mas destacaremos apenas aquelas que nos permitirão avançar em nosso argumento.

"Daniel! Lembra de mim?! Eu penso tanto em você... o Felipe me conta todas as coisas que você faz e de que você gosta. Eu estava com saudade...”. Com essa fala, Guirado o recebeu certa vez em sua casa, passados alguns meses de sua última visita. Ele a olhou com satisfação enquanto andava certeiro em direção à cozinha da casa, mostrando que conhecia o ambiente e reconhecia aquela que lhe falava. Dirigiu-se na sequência ao quarto, onde se jogou na cama, repetindo (retomando e lembrando, provavelmente) com uma vasta gargalhada a brincadeira do encontro anterior.

Em outra ocasião, também na casa de Guirado, eu me ausentei do ambiente da sala para ir ao banheiro por alguns instantes. Quando saí do lavabo, estavam, ele e ela, parados na porta, ela dizia "Ele está aqui, Dani! Viu, eu te disse”. Informou-me que,

\footnotetext{
${ }^{72}$ Disso inclusive já tratamos neste trabalho (Abertura e Capítulo 1.). É um ponto também desenvolvido por Lucas B. M. Silva em sua Tese A Psicanálise da Análise Institucional do Discurso (Silva, 2019).
} 
quando saí inicialmente do cômodo, Daniel ficou olhando ao redor, um tanto perdido, e começou a se agitar e demonstrar certa aflição, em razão de não me ter ao alcance de seus olhos. Ela lhe disse que estava tudo bem, que eu iria voltar, mas como seu olhar permanecia "angustiado", guiou-o até o banheiro onde me encontrava. Segundo o que disse, assim que me viu, acalmou-se. Guirado relata que observou, em outras ocasiões, uma dinâmica semelhante, na qual o Daniel parece ficar "em paz" quando está em minha presença.

Por fim, uma outra vez Guirado pôde presenciar a expressão de desconforto de Daniel, na ocasião se relacionava a um mal-estar físico, uma dor no estômago (como pudemos constatar por alguns sintomas orgânicos típicos). Ela se sentou com ele no sofá e acarinhou sua barriga dizendo "O Daniel está sentindo uma coisa muito ruim aqui [barriga], está doendo. E você não está podendo dizer... é muito chato. Mas eu entendi...”. Talvez o tom carinhoso e sentido de sua fala, talvez o significado intuído das palavras, talvez o toque gentil... não se pode ao certo dizer, mas Daniel respondeu se acalmando, seu choro intenso transformou-se num choro contido. Deixou ser cuidado e medicado.

Por uma constelação feliz de fatores, pude acompanhar situações como essas, que põem em cena o Daniel de sempre, intenso e forte, e ... a Marlene. Sim, porque ao vê-la falar com ele daquela forma, natural, simples e ao mesmo tempo funda, algo de um estranhamento radical se colocava, e não era mais Guirado quem ali estava...mas alguém igual a ele, a mim, que falava a um menino lhe provocando a memória e o afeto, que lhe falava de suas memórias e afetos, que acompanhava a direção de seu olhar e observava as expressões de seu rosto como se fossem frases completas que ele lhe cochichava ao pé do ouvido. 
Não é, portanto, exercício retórico, teórico ou conceitual sustentar que um conceito de discurso como ato abre para a possibilidade de pensar que crianças, como esse nosso Daniel, "são todos personagens que com maior ou menor controle do movimento e da atenção, ou com maior ou menor consciência da funcionalidade de sua comunicação, seguem dizendo, seguem discursando em ato e afetos" (Guirado M. , 2018, p. 137). Em verdade, e para retomar uma fala desta autora, o pensamento e conceituação vem a reboque da experiência concreta.

E se fizemos este détour pela AID, é para dizer que a condição inicial e básica das possibilidades de comunicação do Daniel se constituiu sobre o terreno dessa disposição de considerar que há um discurso, sem palavras, constituído em suas ações, expressões e afetos. Uma disposição que permite tomar elementos de ordem não-linguística como formas de ação sobre as relações, sobre o mundo e sobre os outros.

Nesse sentido, é curioso notar que, na comunicação que Daniel pôde desenvolver, o interlocutor se tornou parte constituinte de seus gesto e sinais. De certa forma, podemos pensar que o outro é o contexto discursivo de sua comunicação. Pois, ainda que não tenhamos claro o alcance que ele tem do sentido e significado de seus gestos, está estabelecida a possibilidade de dizer. E Daniel, a seu modo, parece reconhecer essa condição (de "pôr em relação") de seu discurso, pois não faz os gestos que conhece "no vazio". Pelo contrário, nessas ocasiões, sua atenção e seu movimento podem se voltar para o interlocutor, desde que esse se disponha a isso.

Assim, Daniel estabelece "contatos" na confiança de ser entendido; o lugar de enunciação que exerce pressupõe o de um outro. E essa é uma de suas potentes positividades: a relação como suporte do sentido e da possibilidade de dizer de si. 
Este item parte da ideia que encerra o anterior, a saber: que Daniel tenha as relações que estabelece como suporte dos sentidos e das possibilidades de dizer de si.

Dois fatos que podemos destacar dessa afirmação: $a$. Daniel estabelece relações; b. essas relações sustentam suas formas de comunicação. Se fazemos isso, é para que se evidencie a singularidade (e potência) desse caso. Nós, psicólogos clínicos, que diariamente atendemos crianças com diagnóstico médico de autismo, não raro nos deparamos com formas de expressão linguística características: crianças que repetem frases descontextualizadas, às vezes de modo até estereotipado, que aparentemente não se referem a nada que não a uma "lembrança" ou algo do gênero; crianças que fazem pedidos que parecem soltos ao vento, sem nos dirigir o olhar ou algum outro sinal "pragmático" que indique que a fala é direcionada para nós; crianças que não parecem estabelecer uma conexão, seja pelo olhar, pelo gesto ou pela fala, enquanto brincam “conosco".... Quem convive com esses meninos e meninas com autismo, certamente já se viu em situação semelhante. O curioso em muitos desses pacientes é que seu modo de se relacionar (sim, porque eles se relacionam!) guarda certa especificidade que exige de seu interlocutor, por vezes, sensibilidade e atenção constantes para estabelecer um contato, uma relação, e assim criarem (interlocutor e criança) vias de interação.

Não é o caso de Daniel! Curiosamente, ele tem facilidade e naturalidade no estabelecimento de contatos e relações básicas. É uma questão da sua "postura”, por assim dizer, pois já sabemos de suas dificuldades e limites, mas, apesar deles e com eles, há abertura ao contato interpessoal: ele olha desconhecidos; sorri para crianças brincando; olha com expressão de sofrimento quando está com dores, como quem "pede" ajuda; é 
carinhoso e expansivo, abraça com facilidade as pessoas de quem gosta. É interessante notar também que as pessoas que com ele convivem, muito rapidamente, se apegam a ele, gostam dele, ficam perto, sentem carinho, se compadecem. Daniel é querido em todos os lugares que vai. Até desconhecidos mostram um interesse muito especial por ele e, com facilidade, "interpretam" o que ele está sentindo. Ouvi, muitas vezes, de completos estranhos: "nossa, como ele é/está feliz!"; "Coitado, deve estar com dor...”; "Ele gostou disso, viu?!".

Eu fui uma dessas pessoas que rapidamente se apegou a ele. Felizmente, tudo indica, de sua parte o mesmo aconteceu. Em nosso primeiro encontro, ainda quando Luisa Guirado o atendia e eu só o conhecia através de fotos e relatos, nos sentamos para almoçar. Ele, à minha frente, me olhava sem pausa, com misto de carinho e curiosidade. Anos depois passei a acompanhá-lo e, é difícil dizer ou descrever como, mas uma ligação muito forte se estabeleceu. Os indícios que tenho disso são muitos, desde relatos de pessoas que nos observavam (como Marlene Guirado e os professores e funcionários da escola, e mesmo pessoas da família) que sempre destacaram a sintonia e o companheirismo da dupla de trabalho, até o próprio Daniel que, bastando eu estar presente no ambiente, seu olhar busca sempre o meu, estejamos próximos ou não. De modo simétrico, também é curioso, que estando ele no ambiente, meu olhar também está constantemente em sua busca. Estamos, por assim, no radar um do outro.

Esse vínculo foi e é, até hoje, a condição de nosso trabalho. Foi e é, também, o berço da aprendizagem (programada ou espontânea) de sinais intencionais de comunicação, que se mesclam à expressividade impensada das manifestações de seu corpo e movimento. Na sequência, apresentarei cenas e situações que delineiam essas outras formas de discurso que vieram se somar e se produzir com, pelo e no Daniel. Peço 
desculpas pela primeira pessoa do singular, mas nesse ponto do trabalho não é possível fazer de outro modo. De toda forma, que o leitor não se engane, pretendemos manter o tom analítico-descritivo que é sua marca.

Daniel corre muitas vezes ao longo do dia. É difícil avaliar se gosta ou não, mais prudente seria dizer que correr lhe é um modo muito comum de se movimentar. Eu, nos inícios do acompanhamento, corri diversas vezes junto dele, ao seu lado; ora o ultrapassando, ora ficando para trás, ora esbarrando nele. Tentei fazer desse movimento uma brincadeira ou, no mínimo, ocasião de interação. Com a repetição e certa insistência, dele e minha, em correr, logo se observaram os primeiros sinais de que o meu movimento fazia algum sentido para ele, o "tocava" de algum modo. Quando eu corria em sua frente, ele batia palmas e olhava para os meus pés, um tanto animado com o que via. Eu parava e, então, corria na direção contrária, ele se virava e me seguia, novamente batendo palmas. Criou-se, assim, a primeira brincadeira de que tenho registro entre nós; eu corro - ele vem atrás, ditando o ritmo de minhas passadas com suas palmas.

Tentei inverter os lugares. Pegava em seu braço e falava, "Agora você vai primeiro, Dani!", e com um leve empurrão indicava que era a hora de ele correr. Daniel até aceitou esse novo jogo uma vez ou outra. Mas, mais interessante e significativo, é que ele passou a pegar no meu braço e dar um empurrãozinho para indicar que $e u$ devia correr a sua frente.

Estabeleceu-se assim uma comunicação entre nós, por meio de um sinal espontâneo e não programado, que serviu como um índice de o que ele queria de mim: “Corra, Felipe, Corra!”. 
Inegável o carácter comunicacional destes movimentos e ações de um corpo sobre o outro. Uma comunicação que se estabelece nessa relação, na qual existe, por parte dos dois parceiros em cena, uma atenção aos movimentos do outro, sensibilidade e percepção desses movimentos e uma espécie de entendimento que confirma a expectativa depositada na ação (“agora é a sua vez de correr”). Uma relação marcada pela presença, a constância e a repetição, que são a condição de produção do novo, do acaso, da abertura no discurso de Daniel.

Ainda que aparente contradição lógica (repetição-novo, constância-acaso), não podemos nos furtar da constatação de que, nesse caso, o que permanece e se repete é o que abre espaço para as novas formas de ação. De tal modo que, esse gesto de "segurar o braço e empurrar", nascido com o sentido de disparador do jogo de corrida, foi rapidamente reapropriado por Daniel em outro contexto (como fez quando visitou o professor Lino de Macedo, por exemplo), instrumentando a produção de novos sentidos. Sempre no seio de nossa relação.

Escrevemos algumas páginas acima, que Daniel costumava sair de sala de aula, se a porta estivesse aberta, mas, caso se lhe apresentasse algum impedimento físico (um adulto ou mesmo a porta fechada), ele dava meia-volta e se mantinha andando em sala, sem dar sinal de contrariedade ou outro que indicasse sua "vontade" de sair. Alguns dias depois de termos estabelecido o jogo de corrida e seu disparador (o toque no braço), algo novo aconteceu. De forma quase automática, com muita naturalidade, Daniel pegou em meu braço e me levou até a maçaneta da porta de sua sala de aula, que estava fechada. Indicava com isso que queria sair. Por qual motivo, ainda não sabíamos, mas ele queria e, mais que isso, "dizia" para mim o que ele desejava, sair. 
Do meu lugar, traduzia em palavras esses sinais: "Ah, você quer sair", "Ah, você quer correr". Mostrando, ao mesmo tempo, que eu o entendia, que ele tinha se feito entender e que estava assim legitimada a possibilidade de dizer, de comunicar, numa via que vai dele para mim e de mim para ele.

Certamente, esses sinais de comunicação foram propagandeados para todos aqueles que convivem com Daniel e que precisam e devem se comunicar com ele, o que implica ouvi-lo também. No entanto, foi curioso que, embora com o tempo Daniel tenha passado a utilizar esses gestos com muitas pessoas, inicialmente essa expansão da comunicação não foi tão natural, espontânea e automática como comigo. Seus pais, em casa, por exemplo, precisaram colocar seus próprios braços nas mãos dele, dizendo "Me mostra o que você quer". Pois ele mesmo não tomava a iniciativa de instrumentar seu contato com eles a partir desses atos comunicacionais.

Essa diferença indica, no rebote, o efeito do contexto sobre as ações de Daniel. Um contexto que envolve a relação e o vínculo como organizadores dos sentidos. Nesse caso, a nossa relação guarda uma especificidade no tocante às demais, justamente o fato de ser marcada pela presença, constância e repetição. Não que suas outras interações não compreendam vínculos intensos, fortes e duradouros, mas a regularidade é algo que, por diferentes motivos, desde as exigências domésticas ou do trabalho, até o cansaço da rotina, não se preserva. Por isso, Daniel parece reconhecer e esperar de mim sempre uma resposta às suas ações, justamente porque com regularidade e constância me faço sempre presente como um interlocutor. Por observá-lo atentamente, em cada gesto, movimento e expressão, respondo em ato aos sinais (intencionais ou não) que me dá. E alguns sentidos se "sistematizam", se organizam. 
Um contraexemplo disso: num dia de muito calor, enquanto estávamos em sala de aula trabalhando frente a frente, tive um mal-estar físico, tudo indica uma queda de pressão. Por instantes “desconectei”, a fala ficou lentificada, bem como os movimentos, recebia estímulos do ambiente mas havia um delay em minhas respostas a eles. Foram alguns segundos até me recuperar minimamente. Quando voltei a mim, Daniel me olhava, de modo apreensivo e atento. Estava mais calmo que o normal, manteve-se sentado por longo período, junto comigo (o que é de estranhar, pois normalmente se levanta a todo momento, exigindo que eu o "relembre" da atividade; é claro, nesse dia, se ele tivesse levantado, até eu conseguir reagir, ele já estaria a muitos metros de distância). Daniel, de uma forma inesperada, reagiu à minha "desconexão", se conectando ainda mais comigo. Não é exagerado supor que Daniel estranhou a minha repentina e radical alteração de conduta com ele e reagiu a esse estranhamento.

Se podemos avançar ainda mais no levantamento de hipóteses, talvez Daniel não tivesse reagido ao estranho-Felipe que se lhe apresentava, mas à constatação de que aquele que ali estava não era o mesmo registrado em sua memória. Reagiu ao descompasso entre sua expectativa (a memória de nossa relação) e a situação presente. Daniel tem e guarda registros/marcas de suas relações e vínculos, e os carreia como expectativa para contextos presentes.

Para que nosso argumento se fortaleça, façamos uma breve consideração.

No método da análise aplicada do comportamento, depois da "instalação" de um comportamento-alvo, por exemplo, passa-se a trabalhar a sua generalização, de forma a que o sujeito não se torne dependente de disparadores muito específicos para a emissão do comportamento. Nesse sentido, se diria que o fato de Daniel se comunicar comigo pegando em meu braço e não fazer o mesmo em casa, se deveria ao fato de ele não haver 
generalizado o comportamento, sendo que o que deve ser "generalizado" são os “disparadores” específicos que “controlam” o comportamento em questão. Desse modo, se procederia alternando as variáveis ambientais (pessoas, lugares, ocasiões, etc.) que estavam presentes no contexto inicial do aprendizado. Esta tese, no entanto, numa abordagem como essa, desconsidera a singularidade de Daniel, minha e da relação que estabelecemos. Desconsidera a memória e o afeto dessa relação e com isso mais impede o entendimento do que permite avançar. Daniel não pode ser considerado um conjunto de comportamentos, sem intenções e sem sentidos.

Mais algumas cenas talvez nos auxiliem no caminho de nosso argumento.

Outro desenvolvimento do gesto de pegar no braço foi de Daniel aprender a me chamar à distância. Ele tem, inegavelmente, uma noção espacial muito desenvolvida no que diz respeito à localização dos objetos no ambiente. Por vezes, ele corre sem olhar na direção para que se encaminha e, instantes antes de "trombar" com uma pilastra, muda sua $\operatorname{rota}^{73}$. Assim, as estruturas fixas dos ambientes que ele conhece estão presentes em sua memória, como uma espécie de mapa mental, de tal modo que Daniel nunca tropeçou ou bateu em paredes, mobílias, pilares, etc., que fazem parte constitutiva dos ambientes que conhece, ou seja, ele tem uma memória dos elementos fixos e constantes dos espaços físicos que frequenta. Pois bem, com muita frequência, me encontro ao lado de Daniel, levemente atrás, de tal modo que ele, quase sem precisar me ver, estica sua mão e encontra meu braço para direcioná-lo para o que ele quer (a maçaneta da porta, a porta da geladeira,

73 A psicóloga Mariza Nadolny observou o mesmo quando, ainda pequeno, recebeu Daniel em seu consultório. Chegou a atende-lo apenas algumas poucas sessões. 
a estufa da cantina, etc.). De tal modo que, um pouco como a mobília do ambiente ou as pilastras, possivelmente, eu também me tornei uma parte constantemente presente em seu “mapa mental”, pois Daniel passou a esticar sua mão para trás, como quem fosse pegar meu braço, mas, estando eu distante do toque, ele vira a palma da mão para cima e me olha, num claro reclame à minha presença que ali não está, ao alcance de sua mão.

Assim, embora longe de seus braços e mãos, Daniel fez seu corpo solicitar $\grave{a}$ distância minha presença física a seu lado. Quando me aproximo, ele logo pega minha mão e a direciona para indicar o que deseja.

E a cena mais emblemática dessa comunicação à distância é tal como segue:

Em um domingo, os pais de Daniel foram à casa de um parente próximo que acabara de se mudar. Como haveria pouco ou nada para ele fazer lá, fomos (ele, Luisa e eu) passear num parque e encontrar com uma paciente de Luisa e seus irmãos. Foi uma tarde divertida. Mesmo com todas as preparações que envolvem sair com tantas crianças ao mesmo tempo, Daniel aproveitou do espaço amplo, da grama, também dos ambientes mais calmos (como a biblioteca e seus sofás), andou comigo em uma bicicleta dupla, ensaiou algumas pedaladas, mas sobretudo aproveitou a brisa que batia enquanto viajávamos pela ciclovia do parque. Teve seus pedidos de comida, água e pausa respeitados, sem obrigação de fazer nada além de passear e se divertir. Fomos embora já no final da tarde e, no carro, Daniel estava ameno e feliz, parecia satisfeito com a tarde. Chegamos na casa onde os seus familiares se encontravam e constatei certo descompasso entre o "clima" em que Daniel, Luisa e eu estávamos e o "clima" da casa, agitada pela mudança, com barulhos difusos da televisão, de conversas e de vídeos que o irmão de Daniel assistia no celular. Daniel foi até a 
cozinha, mas nada encontrou na geladeira, apenas alguns pedaços de tomate verde e uma sobra do churrasco do almoço. Não quis comer nada. No andar de cima, seu pai e seu tio utilizavam uma furadeira para instalar um móvel na parede. Eu subi para cumprimentá-los e relatar como tinha sido o passeio, o que deve ter durado cerca de dez minutos. Depois nos despedimos e descemos a escada, o pai de Daniel alguns degraus a frente, de tal forma que ele apareceu na sala antes de mim. Instantes depois, desci a escada, conforme fui "dando as caras" no ambiente, ato contínuo, Daniel que estava sentado, com expressão de desconforto, entre sua mãe e uma outra mulher, me olhou e esticou a mão aberta e espalmada em minha direção. Um gesto em tudo semelhante ao de bebês de colo quando, nos braços de alguém, esticam suas mãos em direção à mãe. Comoção geral e comentários de todo tipo: "Chama o papai também!"; "Nossa, ele gostou do passeio."; "Quer sair de novo".

Tamanha espontaneidade na produção de um gesto de comunicação intencional, que é difícil imaginar como se poderia tomar um ato desses, crivado de sentidos e afetos, como um simples "comportamento" a ser replicado, generalizado.

Talvez, nesse momento, o leitor já tenha configurado para si as imagens das disposições desses variados atores em cena. Não apenas seus lugares, mas certa postura no exercício dessas relações. Temos, em todas essas cenas, Daniel, menino de fácil contato, extrema sensibilidade e fina sintonia. A seu lado, em relação, pessoas que, ora com mais facilidade, ora com menos, podem "sintonizar" e responder a seus atos, gestos, movimentos e expressões. Daniel age e reage a essas respostas, bem como à sua ausência. 
A meu modo, por um exercício constante de instrumentar o pensamento pela análise institucional do discurso, - isto é, a partir de supervisões semanais com Guirado que, a todo momento, me "mostrava" as relações que estabelecia com Daniel, os sentidos que ali se produziam, os modos como se configuravam ações e reações, e me "lembrava" de como se produzia, neste acompanhamento, um discurso possível entre dois parceiros de cena, igualmente potentes, embora singularmente atuantes, na condução dos destinos que construíam para essa história - imagino que eu tenha deixado algumas marcas nos registros do "bloco mágico de Daniel”. Marcas que muitas vezes foram a condição de produção de uma comunicação sui generis, mas potente e necessária.

É no "clima afetivo" dessa relação que seguimos com o texto, mostrando e demonstrando ainda mais cenas da particular expressividade de Daniel.

\section{Eu sou Daniel!}

Nessas supervisões, Guirado nos orientou a realizar com Daniel atividades com o seu nome escrito. Aos moldes de seu trabalho na alfabetização de crianças pelo método montessoriano, ela solicitou que adquiríssemos letras em madeira e, junto de Daniel, o ajudássemos a montar seu nome. Assim fizemos: sentávamos um em frente ao outro; eu lhe explicava que escreveríamos "Daniel" e dava batidinhas em seu peito enquanto repetia seu nome; aí, sobre um anteparo qualquer, íamos conjuntamente posicionando letra por letra de seu nome (sempre na sequência correta da escrita e acompanhada de minha vocalização do fonema). Depois de montarmos o nome completo, apoiava seu dedo e passávamos por cada uma das letras, por fim, novamente com seu dedo traçávamos uma 
linha imaginária abaixo do nome, da esquerda para a direita (ou seja, no sentido da leitura), enquanto eu lia em voz alta, no ritmo de seu movimento, o nome "Da-ni-el". Fazíamos assim uma espécie de leitura em dupla, ele passava o dedinho pelas letras e eu as vocalizava.

Com um pouco de treino e repetição, Daniel, embora não tivesse ainda discriminado cada uma das letras e sua ordem, depois de o nome estar formado, automaticamente passava o dedo embaixo e, com um acréscimo, acompanhava (da esquerda para a direita) com seu olhar, como quem mapeia a escrita.

No dia seguinte a essa constatação, fiz um teste. Sentamos novamente um em frente ao outro, montei eu nome inteiro (DANIEL) com as letras de madeira, e falei pausadamente cada uma das sílabas "DA"-"NI"-“EL”. Em sintonia com os sons que eu produzia, os olhos de Daniel se movimentavam, acompanhando o encadeamento melódico da palavra. De tal forma que, era nítida a impressão de que, para ele, minha fala correspondia em alguma medida àquela Gestalt. Uma Gestalt que compreendia não apenas a palavra "visível" como um todo, mas também o movimento ocular que acompanhava o desenrolar dos sons da minha voz.

Daniel não sabe escrever seu nome. Muito menos podemos dizer que ele reconhece cada um de seus grafemas componentes e os fonemas a eles correspondentes. No entanto, e isso já é muito, Daniel parece reconhecer na imagem gráfica total de seu nome um sentido: Daniel.

Com base nessa hipótese, avançamos um pouco nesse trabalho. Montávamos com ele o nome e batíamos no conjunto de letras com a mão e depois em seu peito, dizendo, nos dois momentos, "Daniel! Daniel". De forma a ampliar as relações estabelecidas, imaginando poder lhe ensinar que o Daniel escrito é (numa linguagem formal, representa) 
este Daniel concreto, aqui. E dizíamos, "É você, o Daniel!”. Perguntávamos-lhe: “quem é o Daniel?". Ao que respondia ora batendo na palavra escrita sobre mesa, ora batendo em seu peito. Ambos estavam corretos, ambas eram formas possíveis de $s e$ reconhecer Daniel $^{74}$.

Em outras situações, o garoto, que agora tinha nome em palavra, demonstrou o mesmo tipo de reconhecimento. Segue a narrativa das cenas.

Nas férias de 2017, fizemos uma colagem de seu nome, com letras pequenas de madeira sobre um papel vermelho. Depois, penduramos o trabalho no mural de fotos do seu quarto, em posição destacada. Alguns dias depois, estávamos brincando de pular em sua cama e ameacei fazer cócegas nele. Para isso, falei seu nome em tom de expectativa, me preparando para a brincadeira. Ao pronunciar os sons de "DA-NI-EL", seu olhar, antes fixo no meu e expectante das cócegas que viriam, automaticamente se voltaram para o papel vermelho, onde estava grafado "Daniel". Um pouco espantado com a prontidão com que ele havia estabelecido a relação, peguei a folha e entreguei em suas mãos, a segurou e mais uma vez fez seus olhos acompanharem as letras. Formou-se assim uma espécie de concerto em que bailavam, ao mesmo tempo, em absoluta sintonia, sua visão, o movimento de seus olhos, as mãos que lhes serviam a imagem, os sons que eu produzia e que seus ouvidos captavam e uma relação dessa forma/imagem/palavra consigo próprio

\footnotetext{
74 Embora tenhamos trabalhado com letras e palavras, e Daniel tenha esboçado algum entendimento de alguma relação entre a grafia do nome e a si próprio, não estamos com isso dizendo que se trata de um processo de alfabetização strictu sensu. É, em verdade, o reconhecimento de si próprio numa "imagem" externa, não propriamente um processo neuropsicolinguístico de decodificação grafema-fonema Fonte bibliográfica inválida especificada.
} 
na brincadeira. Afinal, tudo começa por uma evocação minha, Daniel, em meio a um jogo corporal. Quem capturasse essa imagem fugaz, veria um menino lendo seu nome no papel.

Em seu aniversário, para a mesa que decorava o ambiente, foram colocadas as letras de madeira de seu nome. Bem ao centro, lia-se: "DANIEL". Nessas ocasiões de festa, o pequeno costuma vagar sem parar de canto a outro, ora pegando um docinho aqui, ora um refrigerante ali. Transpassa os ambientes em movimento contínuo, sem muito parar ou se atentar a nada em especial; talvez pelo grande fluxo de estímulos (sensoriais, sociais, ambientais, etc.) que lhe atingem, até como forma de defesa, torna-se um verdadeiro flâneur. Por isso, um fato desse dia se tornou, pelo contraste, significativo. Daniel, em suas andanças, parou em frente à mesa decorativa e ficou alguns segundos olhando-a. Uma de suas amigas que estava próxima notou, e observou que ele mirava seu nome e lhe disse "Sim, você viu que ali está escrito Daniel. É mesmo! É porque hoje é o seu aniversário, o aniversário do Daniel!"’. Ele deu um sorriso de satisfação e seguiu seu rumo.

Este trabalho, inclusive, leva seu nome no título. Imprimi uma capa especial, com o nome real, não o fíctício e, eu e minha orientadora, dissemos para ele que eu estava “escrevendo sobre o Daniel". Mais uma vez, ele olhou as letras garrafais desenhadas no centro da folha, com o movimento de olhos que se tronou característico dessa "leitura" de reconhecimento. Deu um leve sorriso e nos olhou com ar de contentamento.

Por fim, em dezembro de 2018, tendo findado suas aulas e iniciado as férias escolares, passamos a fazer passeios ao Clube que frequenta, sobretudo para brincar na piscina. Quando chego em sua casa, ele me recebe na porta, sempre muito feliz e contente, como quem sabe o que o aguarda: uma tarde muito divertida naquelas águas 
infindas. Vamos para o carro e, no caminho até o clube, vou lhe narrando o que estamos indo fazer, "O Daniel vai ao Clube, nadar na piscina, brincar com a boia. Que nem ele fez todos esses dias" e assim por diante. Nesse dia, ele estava especialmente animado, feliz com essa "prosa" toda. Então, lhe perguntei, "Quem vai no Clube?", ele, num largo sorriso, com os dedos indicadores de ambas as mãos tilintou o próprio peito. "SIM! É o DANIEL quem vai ao Clube!", respondi prontamente.

Cenas como essas denunciam a potente, contínua e dinâmica produção de sentidos desse menino. Sentidos que, numa palavra-nome, podem dar contorno a esse corpo. Seus movimentos, controlados ou erráticos; suas emoções, aflitas ou amenas; seu corpo, em paz ou agitado; suas memórias, prazerosas ou doloridas; tudo isso é Daniel. É, mais importante ainda, um modo de ele se reconhecer Daniel. Esse menino que a certa altura de sua vida parecia alheio a si, cuja expressividade corporal tomava a cena e comunicava por ele o que ele mesmo, intencionalmente, parecia incapaz de dizer, estava agora, ao meu lado no carro, apontando para si mesmo, bradando em movimento e ato que ele era o Daniel! O senhor desse corpo, dessa alegria que sentia por antecipar o prazer da tarde vindoura.

Com isso, a nosso ver, Daniel mostra estabelecer para si um lugar, numa espécie de narrativa interna de sua própria história. Mostra que guarda um registro afetivo do que já viveu, e com ele projeta um futuro para si. Pois sabe o que a minha chegada em sua casa indica: que iremos à piscina, como fizemos antes. Presente, passado e futuro tecendo os sentidos de um gesto-ato de si. E, de forma alguma, penso ser exagero acrescentar mais estas palavras ao seu modo de viver. 
Água, movimento, relações e prazer

Ir à piscina, praia ou qualquer outro ambiente que tenha água em abundância é, o leitor já deve imaginar, um dos grandes prazeres de Daniel. Configura-se como uma experiência completa, ocasião de produção de movimentos, sentidos, sensações, afetos e interações dos mais variados e singulares. Ele fica extremamente à vontade na água, esbanja energia e intencionalidade, seus movimentos "fazem sentido", não erram pelo ambiente, ao contrário, ele parece saber o que quer - mergulhar, espirrar água, pular -, nada em seu fazer parece aleatório. Acompanhemos as cenas.

No clube que frequenta, há quatro piscinas, uma infantil e uma de lazer (ambas "dão pé" para Daniel, afinal, ele já está bastante grande), uma de saltos ornamentais (com cinco metros de profundidade), e uma olímpica (2,5 metros de profundidade). Ele e seu pai costumam ir aos finais de semana e, por vezes, mergulham nesta piscina olímpica, que, obviamente, não "dá pé" para Daniel. Mas, "ele se vira", diz o pai.

Quando fui com ele, no final de 2018, ao entrarmos na área das piscinas, Daniel segurou meu braço e me direcionou para a olímpica. Entendi o que desejava de mim e que me comunicava com seu gesto, mas lhe expliquei que não iríamos lá naquele momento (estava um pouco receoso, afinal, era o responsável por sua segurança nesse ambiente). Entramos, pois, nas piscinas menores. Ao mesmo tempo, engraçado e curioso era ver aquele menino, de $1,60 \mathrm{~m}$ de altura, fazer um malabarismo enorme para permanecer com o corpo todo submerso na piscina infantil, que no ponto mais profundo chega a meros $40 \mathrm{~cm}$. Mas ali permanecemos por um tempo, o que possibilitou algumas interações produtivas: Daniel viu a boia colorida de um menino (Vinícius, 4 anos) e não teve dúvidas, se aproximou e pulou sobre ela, derrubando a mãe de Vinícius que estava 
ali brincando com seu filho. Ela, muito gentilmente, lhe ofereceu o brinquedo, e Daniel, sem dar satisfação, logo começou a pular nele, tentando se manter sobre a água. Quando caía, tentava subir novamente. Ficou muitos minutos entretido com a boia, descobrindo modos de brincar com ela, subindo e descendo, empurrando, afundando, mergulhando sob ela, usando meu corpo como apoio para escalar. Enfim, demonstrou uma variedade e plasticidade de modos de interagir com um objeto, com a permanência, a insistência e o ensaio característicos do jogo lúdico. Um “jogo" que consiste em movimentos, ações, atos de seu corpo, descobrindo o objeto e se descobrindo com ele. Seu corpo, em verdade, é que produz o jogo, seu corpo é o lúdico.

Depois fomos para uma piscina maior (a de lazer), no caminho ainda tentou me puxar para a olímpica mais uma vez, repeti a explicação e a negativa. Nessa outra piscina, um pouco mais funda, Daniel mergulhava e, embora conseguisse encostar os pés no fundo sem problemas, optava por levantá-los e fazer um movimento curioso, como se tentasse chutar a água. Tudo indicava que estava tentando "bater pernas" (como se diz na natação). Fazia isso consistentemente e com muita frequência. Eu, de minha parte, registrei esse evento, aos meus olhos, um tanto estranho.

Sugeri a ele brincadeiras (pular na água, mergulhar, etc.), embora me acompanhasse algumas vezes, seu interesse logo voltava a se concentrar no bater de pernas. Então, comecei a bater pernas em sua frente. Ele riu muito, tentou pegar os meus pés e iniciamos um "pega-pega" aquático. Brincadeira na qual se manteve empenhado e concentrado por vários minutos.

Durante esse período, foi possível notar também a desenvoltura de Daniel na água: ele estava melhor do que nunca, com alguns movimentos de braços e pernas sincronizados, que o faziam deslizar na água de forma muito eficiente. Ato contínuo, por 
uma espécie de insight, lembrei de seu "estranho" movimento de tirar os pés do chão e bater pernas, e atinei com seu sentido: ele estava tentando reproduzir, naquela piscina (que não é funda o suficiente), o que ele faz (e gosta de fazer) na piscina olímpica, cuja profundidade não lhe permite tocar o chão. Falei-lhe isso, que eu tinha entendido a brincadeira, que ele estava tentando nadar ali como faz na outra piscina. Tomei coragem e o convidei para ir lá. Ele, em sinal de entendimento, se encaminhou para a escada e saiu naquela direção.

Ao chegarmos à beira da piscina olímpica, lhe falei: "Pronto, Daniel, vamos lá! Você vai pular?". Ele me respondeu pegando em meu braço e o empurrando para a água, como se me dissesse "Vai você primeiro". Arrumei meus óculos e pulei, ele veio logo atrás. Embaixo d'água era quase possível ouvir suas gargalhadas, tamanha satisfação que demonstrava por estar ali, naquela piscina. E, confirmando a observação anterior, Daniel "batia pernas" e se mantinha, com muita destreza na água, sem afundar. Mergulhava quando queria e utilizava os braços para se projetar. Subia para pegar ar e deixava seu corpo afundar, depois voltava à superfície com a mesma facilidade. Se eu nadasse em sua frente, tentava me seguir e tocar meus pés (como fez na brincadeira de "pega-pega"). Viu uma folha que afundava e mergulhou para alcançá-la. Tudo ali fazia sentido, dissipou-se o estranhamento pelo curioso de seus movimentos; agora eles tinham um lugar, a piscina olímpica, nas pequenas é que aparentavam deslocamento. Em verdade, eu os havia deslocado, não Daniel, que desde o início me dizia onde era seu lugar. Permanecemos muitos minutos nessa piscina, nadando, mergulhando e gargalhando, de um lado a outro. Por vezes, Daniel subia pela escada, dava a volta e mergulhava do outro lado.

O que se pôde perceber é que, desde que chegamos no complexo aquático do clube, Daniel estava me dizendo o que queria. Numa comunicação sem palavras, mas 
muito eficaz, ele me encaminhava, a todo momento para essa piscina olímpica. Eu o entendia, mas lhe negava o pedido, por ter receios (eu, inclusive, lhe expliquei os motivos dessa negativa como sendo um medo meu). Daniel, no entanto, além de me dizer o que queria, me mostrou e demonstrou, nas piscinas rasas, que sabia como se portar naquela outra. Da infantil à de lazer, Daniel só fez repetir (ensaiar) os movimentos que viria a usar para, enfim, nadar na piscina funda. Por isso que pareciam estranhas, curiosas e até engraçadas suas ações anteriores (afundar-se numa piscina extremamente rasa, bater os pés numa piscina em que alcança o fundo), pois com elas Daniel estava tentando pôr em movimento e exercício a realização de sua vontade, anunciada desde o princípio, de nadar livremente naquela outra piscina.

Também por isso, é curioso o movimento desse acompanhamento terapêutico. Dessa vez, foi Daniel, e não eu, quem deu suporte e confiança, afastando assim o receio de fazer algo novo. Ao vê-lo nadar, com tamanha habilidade e liberdade, desfizeram-se os medos e receios. Como dizia seu pai: ele se virava. Mais que isso, ele nadava!

Mais três situações merecem ser apresentadas ainda. A primeira, Daniel olha e observa as crianças na água com muita atenção. Há, na piscina de lazer, um escorregador (tobogã) onde as menores fazem muitas brincadeiras, rindo e falando alto enquanto descem. Isso chama sua atenção, de modo que fica observando, curioso, toda a movimentação. Disse-lhe então: "Daniel, vai lá também! Vou te esperar aqui embaixo”. Embora pareça simples, essa "tarefa" era um desafio (para ele e para mim). Expliquemos. O ambiente estrutura-se da seguinte forma: há o escorregador em uma beirada da piscina (que é muito vasta, com mais de quinhentos metros quadrados de área), a dez metros de distância está a escada que leva para fora da piscina, além disso o tobogã tem em torno 
de quatro metros de altura e conta com outra escada para chegar ao seu topo, de onde se parte para escorregar. Era um desafio pois a maioria das ações de Daniel é instantânea, fugaz, breve, não se estendem no tempo e no espaço. Já essa que eu lhe propunha, pelas distâncias envolvidas, exigia que Daniel se mantivesse, por conta própria, longos segundos numa mesma tarefa, e de mim, que me mantivesse à distância, "apenas" observando, eu não poderia contornar seu movimento e suas direções (indicando onde era a escada, que estava na hora de sentar, empurrar com as mãos, etc.). Ele estava por sua conta e risco.

Mais uma vez, ele mostrou sua competência. Saiu da piscina, caminhou até o tobogã, subiu suas escadas e de lá de cima me olhou. Gritei palavras de incentivo e ele, com movimentos cuidadosos, lentamente se sentou, ouviu mais algumas palavras minhas e deu o empurrão que o faria escorregar até a água, onde eu estava. Aplaudi com muito orgulho e, bonito ver, uma moça que assistia a tudo também o fez, bradando "É isso, Daniel!’. E eu, confiava cada vez mais em suas capacidades de se dar os prazeres e satisfações que deseja, de traçar, no limite de suas possibilidades, os seus próprios caminhos, para seu corpo, seus movimentos, e parte da sua vida. Talvez a isso possamos chamar autonomia.

A segunda situação se refere ao momento de ir embora das piscinas. Há uma ducha de água doce na área aquática, para que os banhistas possam remover o cloro de seus corpos. Sempre, antes de irmos, aviso Daniel que nosso tempo está se esgotando, deixoo brincar mais um pouco e então nos encaminhamos para essa ducha. Lavamo-nos e, no caminho da saída, ofereço algum objeto para Daniel "me ajudar a levar", uma bola, um óculos, uma camiseta. Ele, de modo muito inteligente, ao passarmos por qualquer uma das piscinas, arremessa o objeto que carrega na água. 
A inteligência de seu ato está na saída que inventa para esticar um pouco mais suas horas de diversão, pois sabe, de algum modo, que alguém terá que pular na água para pegar. Eu ou ele, não importa, de qualquer forma teremos mais uns minutos de piscina. Assim, mesmo não falando, Daniel pode ser tão criança como qualquer outro, fazer peraltices e traquinagens visando a um único objetivo: continuar a brincar ${ }^{75}$.

Por fim, a terceira situação. Nessas ocasiões, não se sabe ao certo o porquê, mas o carácter prazeroso da atividade deve ser determinante, Daniel se mostra em suas máximas potências e competências. O "menino que não para", e com isso parece não controlar seus movimentos, na água, é capaz de parar, relaxar seu corpo e flutuar, parar em cima do escorregador, parar por sobre a boia, parar com seu corpo todo submerso nas fundas águas daquela piscina olímpica. O "menino que não fala", foi capaz de falar... pronunciou duas palavras, em alto e bom som. Absolutamente significativas: "água" e "não". A primeira, enquanto brincávamos, lhe disse algo sobre como estava divertida aquela água e ele repetiu a última palavra, pronunciando "a-u-a". A segunda, também dentro da piscina, eu lhe perguntei se queria boiar, Daniel se desvencilhou dos meus braços, fez acompanhar de seu movimento de corpo um sonoro "não", em correta pronúncia. 
Para encerrarmos este capítulo, ainda que assumindo o risco de redundância, é preciso marcar o contraste entre as cenas que apresentamos neste trabalho. Aquelas de seu início, que chamamos de exemplares, mostram um menino "perdido" entre um corpo incontrolável em seus movimentos, sensações, necessidades e um ambiente por vezes insensível e "cego" a Daniel, que lhe demanda e exige posturas e atitudes impossíveis àquela altura. As que apresentamos nesse capítulo, por outro lado, põe em cena e movimento um menino-criança, produzindo sentidos em suas brincadeiras, entendendo e se fazendo entender por sinais, gestos e até falas, impondo intencionalidade às suas ações, com movimentos de corpo que desenham atitudes completas e controladas, um menino que $f a z$ coisas, num exercício competente de se comunicar, de se relacionar, de brincar, de descobrir, de inventar... de viver.

Sem porém, é preciso dizer que esses modos de viver (absolutamente intencionais e meaningfull) coexistem, ainda hoje, à expressividade impensada de algumas formas de sua comunicação. Compõem a complexa tessitura desse corpo produtor de sentidos. Sua gritante corporeidade permanece, resiste e insiste, impõe-se e, de certa forma, instrumenta o exercício de viver de Daniel. Não é, portanto, que se opõe, num mesmo garoto, mecanismos/funções "evoluídas" e "arcaicas", pois, em casos complexos como esse, não devemos pensar com um crivo normotípico ou valorativo. Trata-se, isso sim, de um discurso que, ao mesmo tempo e ato, põe em cena repetição e novidade, acaso e constância, acontecimento e permanência.

Não há uma linha contínua entre um ponto e outro, como se a passagem do tempo pudesse levar Daniel de um lugar de incomunicabilidade até outro, onde ele pode ter uma vida completa no mundo, com intencionalidade, comunicação, produção de sentido. Não. 
O que acontece são momentos, situações que, num determinado contexto e por uma configuração de fatores, acabam sendo ocasião de sentidos com e para essa corporeidade absolutamente intensa que é Daniel.

Sem ter uma linha contínua, esses elementos todos se entrelaçam e configuram um quadro complexo. Mas há o fato de Daniel poder contar com alguém que, no meu lugar, possa narrar essa história, e narrar justamente destacando os pontos de virada, de produção de sentido, de acaso que a fazem tão singular.

Justamente esse menino que, por muito tempo e por diversos motivos, permaneceu, não incapacitado, mas tolhido nas possibilidades de dizer, porque nem sempre contou com um intérprete, um "tradutor", que pudesse acompanhar seu movimento e reverberar em palavras os sentidos de seus atos. Daniel está, a todo momento, produzindo sentidos, e não foi, portanto, nosso acompanhamento que os produziu. Isso é de competência e potência de Daniel. Mas foi, sim, por esse acompanhamento que os sentidos puderam ser "vistos", reconhecidos por seu interlocutor, puderam se tornar discursos. De minha parte, "apenas" o acompanhei, com uma observação atenta, uma atenção curiosa ao vai-e-vem de seus movimentos e ações, e só por isso pude reverberar e responder a ele. Foi essa, não obstante, a condição de poder, nesta pesquisa, mostrar em ato a produção de subjetividade de um corpo, de um menino, que sem palavras para dizer é absolutamente competente e incisivo na produção de sentido. Enfim, Daniel é sujeito de sua história, como se costuma dizer em certo viés filosófico. É sujeito do e no discurso que se tece em contextos cotidianos em que ele pode ser reconhecido como tendo condição de enunciar.

Ter chegado a esse ponto da produção do trabalho e da escritura é digno de valia e nos enche de responsabilidade. Afinal, o que é esse trabalho? É um estudo de caso? 
Sim, é um estudo de caso. Mas é um estudo de caso que guarda um conjunto de peculiaridades. A peculiaridade de ele ser um estudo em AID e de um "caso" tão singular quanto este Daniel, mas isso já se discutiu nos começos da escritura. A outra peculiaridade, só agora podemos dizer, é de ser um estudo de um caso que é pinçado e vivido na intensidade e envolvimento que se tornaram característicos desse acompanhamento. Daniel é um menino pelo qual tenho imenso carinho. É um menino pelo qual choro. Com quem me preocupo. Não só no plano acadêmico e conceitual, mas como pessoa e como pai. Daniel é, inclusive por isso, ícone, Daniel é um nome que se repete na vida de tantos meninos, meninas. Que repete a história de tantas pessoas, adultos, crianças, jovens que, hoje, se encontram nessa condição de precária comunicação, de ações e comportamentos que extrapolam suas condições de controle do próprio corpo. Meninos e meninas, homens e mulheres, que, não obstante, vivem, produzem cotidianamente sentidos. Homens e mulheres, adultos, como um dia Daniel será, que estão e estarão nesse mundo. Nesse nosso mundo cuja palavra, cuja lógica, lhes são um tanto estranhas. Um mundo que, no entanto, pode se render frente a esses corpos de corporeidades irrestritas que, em determinadas condições, podem se fazer plenos ao navegar em uma piscina olímpica. Essa é uma vida que lhes é possível. E que seja essa também a nossa vida.

Vida que segue. 


\section{Bibliografia}

Damásio, A. (1994/2012). O Erro de Descartes: emoção, razão e o cérebro humano. São Paulo: Companhia das Letras.

Damásio, A. (1999/2015). O mistério da consciência: do corpo e das emoções ao conhecimento de si. São Paulo: Companhia das Letras.

Dew-Hughes (org.), D. (2004). Educating Children with Fragile X Syndrome: A MultiProfessional View (e-book). London: RoutledgeFalmer.

Equipe Novo Olhar. (s.d.). Equipe Novo Olhar. Fonte: http://www.equipenovoolhar.org/

Foucault, M. (1971/1996). A ordem do discurso. São Paulo: Edições Loyola.

Foucault, M. (1975/1977). Vigiar e punir. Rio de Janeiro: Editora Vozes.

Foucault, M. (1976/1985). História da sexualidade I: a vontade de saber (7 $7^{\mathrm{a}}$ ed.). Rio de Janeiro: Ed. Graal.

Foucault, M. (1978/2010). Sobre a história da sexualidade. Em M. Foucault, Microfísica do Poder. São Paulo: Graal.

Foucault, M. (1979). Verdade e Poder. Em M. Foucault, Microfísica do Poder (pp. 1-14). Rio de Janeiro: Edições Graal.

Foucault, M. (1983/1995). Sujeito e Poder. Em P. Rabinow, \& H. Dreyfus, Michel Foucault: uma trajetória filosófica para além do estruturalismo e da hermenêutica. Rio de Janeiro: Forense Universitária.

Foucault, M. (2006). Ditos e Escritos IV: Estratégia, Poder-Saber (2ª ed.). Rio de Janeiro: Forense Universitária.

Freud, S. ([1914]1918/1976). História de uma neurose infantil. Edição Standart Brasileira das obras completas de Sigmund Freud, XVII. (J. Salomão, Trad.) Rio de Janeiro: Imago.

Freud, S. (1919/1976). O estranho. Edição Standart brasileira das Obras Completas de Sigmund Freud, XVII, 271-314. (J. Salomão, Trad.) Rio de Janeiro: Imago.

Freud, S. (1925/1976). Uma nota sobre o "bloco mágico". Edição Standart Brasileira das obras completas de Sigmund Freud, XIX. (J. Salomão, Trad.) Rio de Janeiro: Imago.

Gotham, K., \& et. al. (2008). A replication of the Autism Diagnostic Observation Schedule (ADOS) revised algorithms. J Am Acad Child Adolesc Psychiatry, 47(6), pp. 642-651.

Guirado, L., \& Guirado, M. (2014). Tratamentos do autismo: a direção do olhar. Saarbrücken: Novas Edições Acadêmicas.

Guirado, L., \& Guirado, M. (2014/2018). A direção do olhar nos tratamentos do autismo. Curitiba-PR: Appris. 
Guirado, M. (1987/2004). Psicologia Institucional (2a rev. e ampl. ed.). São Paulo: E.P.U.

Guirado, M. (1992). Transferências e Transferências. Revista Psicologia: Ciência e Profissão, $n .20$.

Guirado, M. (1995/2006). Psicanálise e Análise do Discurso: matrizes institucionais do sujeito psíquico. São Paulo: E.P.U.

Guirado, M. (1995/2018). Análise do discurso e Psicanálise: matrizes institucionais do sujeito psíquico. São Paulo: Lumen Juris.

Guirado, M. (2000). A clínica psicanalítica na sombra do discurso: diálogos com aulas de Dominique Maingueneau . São Paulo: Casa do Psicólogo.

Guirado, M. (2005). O Caso do Psicodiagnóstico: um Estudo Institucional. Psicologia USP, 16(4), 11-32.

Guirado, M. (2007). A clínica psicanalítica como análise de discurso. Em M. Guirado, \& R. Lerner, Psicologia, Pesquisa e Clínica: por uma análise institucional do discurso (pp. 195-222). São Paulo: Annablume e Fapesp.

Guirado, M. (2010). A análise institucional do discurso como analítica da subjetividade. São Paulo: Annablume; Fapesp.

Guirado, M. (2015). Clínica e Transferência na Sombra do Discurso: Uma analítica da subjetividade. Psicol. USP [online], 26(1), pp. 108-117. doi:0103-656420140022

Guirado, M. (2016 ). Acolhimento em Abrigos: direito à construção de narrativas da própria história. Em C. F. Psicologia, 25 anos do ECA: Refletindo sobre sujeitos, direitos e responsabilidades. São Paulo: CFP.

Guirado, M. (abril de 2018). Uma analista do discurso no espectro de tratamentos do autismo. Psicologia USP, 29(I), pp. 135-145. doi:0103-656420170056

Guirado, M., \& Lerner, R. (2007). Psicologia, Pesquisa e Clínica: por uma análise institucional do discurso. São Paulo: Annablume e Fapesp.

Guirado, M., Martins-Afonso, F., \& Guirado, L. (2012). Loucura e Neurose em Freud: a cena originária da clínica psicanalítica em análise. Curitiba: Appris.

Lima, M. (2007). O paciente e o término da análise no discurso de psicanalistas: uma análise institucional de discurso. Dissertação de Mestrado. São Paulo: Instituto de Psicologia, Universidade de São Paulo.

Lord, C., Rutter, M., Goode, S., Heemsbergen, J., Jordan, H., Mawhood, L., \& Shopler, E. (1989). Autism diagnostic observation schedule: a standardized observation of communicative and social behavior. J Autism Dev Disord, 19(2), pp. 185-212.

Luria, A. (1973/1981). Fundamentos de Neuropsicologia. São Paulo: Ed. Universidade de São Paulo.

Maingueneau, D. (1989). Novas tendências em Análise do Discurso. Campinas: Pontes Ed.

Maingueneau, D. (1995). O Contexto da Obra Literária. São Paulo: Martins Fontes. 
Maingueneau, D. (2000). Aula - Sobre o Discurso e a Análise do Discurso. Em M. Guirado, A clínica psicanalítica na sombra do discurso: diálogos com aulas de Dominique Maingueneau (pp. 21-31). São Paulo: Casa do Psicólogo.

Pearl, P., Carrazana, E., \& Holmes, G. (Novembro de 2001). The Landau-Kleffner Syndrome. Epilepsy Currents, 1(2), pp. 39-45.

Sacks, O. (1997). O homem que confundiu sua mulher com um chapéu. São Paulo: Companhia das Letras.

Sacks, O. (2010). O olhar da mente. São Paulo: Companhia das Letras.

Silva, L. (2019). A Psicanálise da Análise Institucional do Discurso. São Paulo: Tese de Doutorado, Instituto de Psicologia da Universidade de São Paulo.

Skinner, B. (1948/1975). Walden Two: Uma sociedade do futuro. São Paulo: Herder.

Spitz, R. (1957/1978). O não e o sim: a gênese da comunicação humana. São Paulo: Martins Fontes.

Spitz, R. A. (1965/2004). O primeiro ano de vida. São Paulo: Martins Fontes.

Viaro, R. (2011). Modos de subjetivação na formação em psicanálise: uma análise institucional de discurso. Dissertação (Mestrado). Curitiba: Universidade Federal do Paraná. 


\section{Anexos}

[Sobre A. R. Luria]

Destacaremos elementos do material consultado, que consideramos importantes para os objetivos deste trabalho, o acadêmico, bem como aqueles que foram relevantes, a certo momento, na história do acompanhamento do menino Daniel. Por importante ou por relevante entenda-se: o que, por algum motivo, em determinado contexto, deu nome e sentido a algo disperso e opaco; aquilo que, ainda que não se saiba o porquê, parece relacionar-se em forma e semelhança à ação de Daniel no mundo. Comecemos.

Uma breve apresentação: Alexander R. Luria foi um neurologista/neuropsicólogo russo, que produziu a maior parte de seus estudos em meados do século $\quad \mathrm{XX}$. Um de seus trabalhos mais fundamentais, lidos e estudados até hoje, é o Fundamentos de neuropsiologia (Luria, 1973/1981). Nele, pode-se dizer, Luria realoca as bases epistemológicas da neurologia e da neuropsicologia, por meio de uma revisão sistemática e radical de conceitos-chave na configuração dessas áreas do saber. Além disso, propõe um modelo teórico, conhecido como o de sistemas funcionais.

Luria é tido como um dos pioneiros de uma Neurologia mais dinâmica, mais pegada à vida e às formas de viver, em oposição a uma tradição de teorias e teóricos que produziam um discurso que versava sobre o cérebro como uma máquina de processamento de informação (a metáfora atual, embora impensável a Luria, é a do computador). 
Assim, é possível notar (e com isso nos desculparmos) a envergadura do autor que temos em mãos para nossos comentários. Para não sermos infiéis nem levianos a suas palavras, de antemão esclarecemos: não trataremos, nesta ocasião, da Obra de Luria. Também não trataremos de uma obra por inteiro. Em verdade, para nossos fins, basta neste momento trabalhar com a primeira parte do livro "fundamentos de neuropsicologia”, na qual o autor trata justamente dos... fundamentos. Não abordaremos a fundo seu modelo teórico (Sistemas funcionais), nem os estudos com as lesões cerebrais e os distúrbios neurológicos decorrentes.

Vamos lá.

No texto, Luria reexamina três conceitos básicos: o de função, o de localização e o de sintoma (ou perda de função) (Luria, 1973/1981, p. 12).

Sobre função, o autor afirma que: "Os investigadores que examinaram o problema da 'localização' cortical de funções elementares mediante estimulação ou exclusão de áreas cerebrais locais deram ao termo 'função' o significado de função de um tecido particular." (idem, p. 12). O que implicaria entender o termo tal como ele seria usado para descrever a função de um tecido vivo ou um órgão do corpo: a secreção da bile é função do fígado; a secreção da insulina, do pâncreas. Este é, segundo Luria, um dos usos possíveis do termo função, mas não seu único. Assim, ainda apoiado numa medicina que trata do "corpo" e não do "cérebro", faz uma distinção importante no uso do termo. Diz que a função da respiração ou a função de digestão, são processos que não podem ser atribuídos a um tecido em particular. Por exemplo:

$\mathrm{O}$ ato de digestão requer o transporte de comida ao estômago, o processamento dos alimentos sob a influência do suco gástrico, a participação das secreções do fígado e do pâncreas nesse 
processamento, o ato de contração das paredes do estômago e do intestino, a propulsão do material a ser assimilado ao longo do trato digestivo e, finalmente, a absorção dos componentes processados dos alimentos pelas paredes do intestino delgado. (Luria, 1973/1981, p. 12)

Desse modo é que formula a ideia de função como um sistema funcional ${ }^{76}$ completo que é exercida por diferentes componentes trabalhando em conjunto orquestradamente, em oposição à ideia de "função simples".

A ideia de sistema funcional acrescenta ainda alguns aspectos ao conceito. $\mathrm{O}$ primeiro é que pressupõem um conjunto complexo de estruturas (no caso da digestão, por exemplo, todos os órgãos do aparelho digestório). O segundo é a mobilidade de suas partes constituintes, definida como "A presença de uma tarefa constante (invariável), desempenhada por mecanismos diversos (variáveis), que levam o processo a um resultado constante (invariável)" (Luria, 1973/1981, p. 13). Trocando em miúdos, isso significa que a "função" mantém-se, embora os mecanismos pelos quais será levada a cabo podem variar, não influenciando no resultado final.

Por exemplo, se o grupo principal de músculos em ação durante a respiração (o diafragma) para de agir, os músculos intercostais são recrutados; se, entretanto, por qualquer razão, estes últimos estão prejudicados, os músculos da laringe são mobilizados e o animal, ou ser humano, passa a deglutir ar, que alcança, assim,

${ }^{76}$ O termo "Sistema funcional”, segundo Luria, foi cunhado por Anokhin. 
os alvéolos pulmonares por uma via completamente diversa. (Luria, 1973/1981, p. 13)

Por fim, um segundo aspecto é a composição complexa desses sistemas funcionais, nos quais está sempre presente uma série de impulsos aferentes e eferentes (idem, p. 13). Isso implica que sistemas funcionais não são apenas "unidades" inteiramente ativas ou passivas, mas que adaptam-se ou regulam-se, por assim dizer, constantemente em face à tarefa e as condições que os afetariam.

Assim, defende Luria, a ideia de sistema funcional completo e complexo poderia, ainda com mais razão, ser aplicada no entendimento da ação humana. O exemplo que dá, característico da neurologia, é a marcha, o andar; uma ação motora, portanto. Diz ele:

Os movimentos de uma pessoa que tenciona alterar sua posição no espaço, ou executar uma certa ação, não podem jamais efetuar-se simplesmente por meio de impulsos eferentes, motores. Visto que o aparelho locomotor, com as suas articulações móveis, tem, como regra, um número muito grande de graus de liberdade, que esse número é multiplicado em função de grupos de articulações participarem no movimento, e que cada estádio do movimento altera o tono inicial dos músculos, o movimento é em princípio não controlável meramente por impulsos eferentes. Para que um movimento se realize deve haver uma correção constante do movimento iniciado; impulsos aferentes fornecem informações sobre a posição no espaço do membro que se está movendo e sobre a modificação no tono dos músculos, a fim de que possa ser introduzida qualquer correção que se faça necessária no curso do movimento. Somente uma estrutura assim complexa do processo de locomoção pode satisfazer a condição fundamental da 
preservação da tarefa invariável, garantindo a sua execução por meios variáveis e a consequente obtenção de um resultado invariável por esses meios dinamicamente variáveis. O fato de que todo movimento tem o caráter de um sistema funcional complexo e de que os elementos que realizam tal movimento podem ser cambiáveis entre si é claro por poder ser o mesmo resultado alcançado por métodos totalmente diferentes. (Luria, 1973/1981, pp. 13-14)

Finaliza dizendo que a estrutura sistêmica é característica ainda mais forte dos atos mentais mais complexos, como a fala, as praxias e gnosias, que não poderiam ser pensadas e entendidas como faculdades isoladas.

Abre-se então o segundo problema, o da localização. Por definição, se função é entendido com um sistema funcional, a localização da função não poderia, por sua vez, restringir-se a determinada região específica do cérebro ou do córtex cerebral em se tratando de atividades humanas complexas.

Luria faz dois apontamentos em sua argumentação. O primeiro, num diálogo com Vygotsky, é o de que as formas complexas da atividade humana (e exclusivamente humana) são sempre baseadas em auxílios externos, como a linguagem, por exemplo. Configuram-se como "ações mentais", e essas não podem ser entendidas sem se considerar essa relação com o mundo "de fora". Um exemplo são os recursos que utilizamos para lembrar de alguma coisa: um risco que fazemos na mão ou o nó em um lenço. Esses elementos externos auxiliam na construção de relações funcionais entre partes isoladas do cérebro. Isso porque, numa visão básica, o risco na mão remete-nos à tarefa interrompida, ou seja, estabelece uma específica conexão entre memória, percepção e raciocínio, antes inexistente. Segundo as palavras de Luria: “medidas historicamente 
geradas para a organização do comportamento humano determinam novos vínculos na atividade do cérebro humano" (Luria, 1973/1981, p. 16).

O segundo apontamento é que a localização de processos mentais nunca seria estática e constante, mas ela se deslocaria e se dinamizaria durante o desenvolvimento da criança. Realizar uma tarefa motora, nos primeiros anos de vida, é algo expandido, precário e que requer auxílios para seu desempenho a contento; com o desenvolvimento da criança, a habilidade torna-se um processo condensado e automático.

Nos estágios iniciais, por exemplo, o ato de escrever depende da memorização da forma gráfica de cada uma das letras. Ele ocorre por meio de uma cadeia de impulsos motores isolados, cada um dos quais é responsável pela realização de apenas um elemento da estrutura gráfica; com a prática, esta estrutura do processo é radicalmente alterada e o ato de escrever convertido em uma "melodia cinética" única, não mais requerendo a memorização da forma visual de cada letra isolada ou impulsos motores individuais para a feitura de cada traço. A mesma situação se aplica ao processo no decurso do qual o ato de escrever um engrama altamente automatizado (como uma assinatura, por exemplo) deixa de depender da análise do complexo acústico da palavra ou da forma visual de suas letras individuais e passa a ser desempenhado como uma "melodia cinética” única. (Luria, 1973/1981, p. 17)

Assim, as atividades humanas dependeriam de zonas corticais funcionando em concerto. Não haveria, nos processos mentais superiores, uma localização estrita e estática de uma função mental, mas uma localização dinâmica, a depender do funcionamento polivalente de diversos núcleos e regiões corticais. 
Uma derivação dessa ideia nos é particularmente cara, porque trata do desenvolvimento infantil e, por conseguinte, permite subscrever os transtornos do desenvolvimento. Ela consiste em descrever a ontogênese dessa organização interrelacional dos processos mentais, ou, em outras palavras, como as funções mentais desenvolvem-se como um concerto de sistemas de zonas corticais em funcionamento. No início do desenvolvimento, a atividade mental repousa sobre uma unidade basal de processamento, “em estágios subsequentes ela não apenas adquire uma estrutura mais complexa, mas também começa a ser desempenhada com a participação estreita de formas de atividade estruturalmente superiores" (idem, p. 17).

Por exemplo, segundo Luria (idem, pp. 17-18), a criança pensa em termos de percepção visual e memória, ou seja, ela pensa por meio da recordação (podemos acrescentar aqui ainda a ideia de Piaget, dos períodos sensório-motor e também do intuitivo, em que o pensamento está muito colado na percepção sensorial, haja vista os erros de reversibilidade nas provas operatório-concretas, cometidos por crianças que não teriam alcançado esse estágio do desenvolvimento cognitivo). Na adolescência e na vida adulta, no entanto, as formas de generalização e abstração estão altamente desenvolvidas e o indivíduo é capaz não só de pensar com base nesses princípios, mas, incrivelmente, a reflexão passa a influenciar as formas básicas da percepção; "pessoa na verdade começa a perceber ou recordar por meio da reflexão" (p. 18). Isso nos leva a uma regra da localização dinâmica, a de que uma lesão nos períodos iniciais do desenvolvimento acarreta, por efeito sistêmico, efeitos em regiões corticais superiores sobrepostas funcionalmente à região lesada. O contrário é também válido: lesões em adultos em regiões corticais superiores produzem efeitos em zonas basais ou inferiores que passaram a depender delas. 
É justamente esse nosso ponto de interesse no conceito de localização. O cérebro do Daniel, até que se prove o contrário, não tem lesão anatômica, mas o pequeno apresenta um conjunto amplo de "disfuncionalidades" em regiões corticais inferiores, principalmente na esfera da percepção básica, no plano das intensidades e dos efeitos de estímulos e sensações "normais" sobre ele. Para ele, elas não são normais. Se essa regra é válida, é de se esperar que Daniel apresente, em suas atividades e ações mais complexas, traços ou sintomas desse efeito sistêmico. "Seu mundo" sensorial e "interno", provavelmente, é muito diferente do nosso.

Por fim, a revisão do conceito de sintoma, que é, para nossos fins, o ponto central desse texto. Luria, como nos outros dois pontos, discute com a "versão clássica" do conceito, nesse caso: um sintoma específico indica uma lesão numa região específica do cérebro; todo sintoma $x$ seria causado por uma lesão na região $x$ '. No entanto, no caso de atividades e funções mentais superiores, ou seja, em se tratando de sistemas funcionais complexos cuja localização é dinâmica, como fica essa equação entre lesão e sintoma? Ela não é tão clara e unívoca assim...

O exemplo de que Luria se serve é o do "sintoma" apraxia. Diz que práxis, como ação motora planejada e organizada, é um sistema funcional complexo e completo, assim, uma lesão em qualquer de seus elementos constituintes ocasiona um distúrbio práxico. No entanto, diferentes lesões "produzem" quadros de apraxia muito diversos. Há um conjunto variado de elementos aferentes para a regulação e organização do movimento, um grupo deles é a aferentação cinestésica, que fornece o grau de tônus do músculo e a posição das articulações. Lesões nessa organização funcional levam a casos de um distúrbio do movimento chamado apraxia cinestésica, caracterizada por uma incapacidade de o indivíduo, por exemplo, “colocar a mão na posição necessária para a 
ação manipulatória que ela deve efetuar" (Luria, 1973/1981, p. 20). Diferentemente, o movimento também requer para sua execução aferentes visuo-especiais (de localização do corpo e dos objetos no espaço, por assim dizer), uma lesão na área responsável por esses componentes acarreta um distúrbio práxico completamente diverso, caracterizado por uma dificuldade em colocar os membros do corpo na posição espacial necessária para realizar uma tarefa, o indivíduo "não acerta" o copo, por exemplo, que deseja segurar, ou move o garfo que segura sempre na vertical, em vez de na horizontal para poder levá-lo à boca.

Luria prossegue com os exemplos. Para um movimento ser levado a cabo, requerse, em verdade, um conjunto de movimentos consecutivos; onde os primeiros precisam ser "desnervados" ou inibidos para que os próximos tomem seu lugar e assim por diante. A tendência, no desenvolvimento, é que os movimentos tornem-se "melodias cinéticas", como é, por exemplo, escrever uma palavra para um adulto alfabetizado, não há o que pensar no que diz respeito a como grafar cada uma das letras, o ato motor de escrever uma palavra é cineticamente melódico, fluido. Assim, lesões que afetam a "organização cinética do movimento" produzem um quadro de apraxia característico, apraxia cinética, "manifestando-se como incapacidade para sintetizar os elementos motores em uma melodia sucessiva, suave, e como dificuldade para desnervar no momento adequado um elemento do movimento que tenha sido completado e passar suavemente de um elemento motor ao elemento seguinte" (Luria, 1973/1981, p. 21). Há ainda, por fim, uma "apraxia dirigida a metas", ocasionada por lesões em áreas responsáveis pela organização de tarefas motoras e intenções, sobremaneira os lobos frontais; não nos deteremos mais longamente nesta última. 
A considerar pelos exemplos acima, o sintoma apraxia não é uma unidade descritiva precisa de um distúrbio de funções neuropsicológicas, uma vez que o controle voluntário do movimento (como uma função mental superior) é um sistema funcional complexo e completo, sua análise deve levar em consideração que ele "incorpora inúmeras condições ou fatores dependentes do funcionamento em concerto de todo um grupo de zonas corticais e estruturas subcorticais, cada uma das quais dá a sua contribuição peculiar para a realização do movimento e contribui com o seu fator peculiar para a estrutura do referido movimento" (Luria, 1973/1981, p. 22).

Luria encerra dizendo que, portanto, a primeira "tarefa do investigador é estudar a estrutura dos defeitos observados e qualificar os sintomas" (idem, p. 22). Ou seja, observar e discriminar de modo a levar a uma identificação do fator básico por trás do sintoma.

Esse trabalho de revisão conceitual de Luria nos interessa por diversos motivos. O primeiro é a valiosa regra de prudência: observar e analisar. Em outras palavras, em uma área diversa e por diferentes procedimentos, a AID também preconiza a observação, a descrição e a análise. No entanto, já o sabemos, não é possível estabelecer uma ponte tão direta assim entre lá e cá. Observar e discriminar como neurologista é diferente de observar e discriminar como psicólogo (e analista institucional do discurso). A ponte, deve se estribar em alguma base, para não correr o risco de desabar. 
Pois bem. Dois elementos permitem a construção desses alicerces: o discurso característico de Daniel e sua interface como um sintoma neuropsicológico. Elementos esses que são inalienáveis na história desse garoto.

Se objetivamos responder à pergunta “como é Daniel?" e por consequência passamos a descrever sua ação no mundo, sobre as pessoas, suas reações, suas relações, como fizemos ao longo deste trabalho, salta aos olhos seu movimento, sempre constante, inquieto, impulsivo. Salta aos olhos também certa "inabilidade" naturalmente posta em sua ação. Por exemplo: ele parte com seus dedos a comida (um pão de queijo, talvez) que lhe é dada, e não com os dentes, só aí a direciona à boca, onde a deposita lá no fundo, entre os molares. Se impede-se que parta o alimento, segurando uma de suas mãos por exemplo, Daniel leva a comida à boca e tenta cortá-la com os dentes, mas nesse movimento percebe-se sua dificuldade: os dentes não são tão eficientes, ele não movimenta a mandíbula para facilitar a mordida, e quando, por fim, arranca um pedaço, fica com ele longo segundo entre os lábios, parece que pensando como empurrá-lo para os dentes posteriores. Assim, partir o alimento com as mãos lhe é algo natural, automático em oposição à pausa e renitência do ato "antinatural" de morder. Daniel, faz uma parte do processo de mastigação com as mãos. Daniel vive com/em um mundo em que o natural e "adaptado" é estranho e custoso.

Uma cena como essa só foi assim descrita e analisada porque pensamos com e pela visada da AID. E uma cena assim como essa pode ser pensada no diapasão do sintoma de Luria, como um sistema funcional onde resultado é o mesmo, mas os estranhamentos (nos termos de Luria, desadaptação) em seu exercício nos dão as pistas sobre o "como é Daniel". Inverte-se assim uma equação importante: sintoma como algo não-funcional dá lugar ao "sintoma" como um modo possível de ser e de agir. Se é tão 
difícil com os dentes, quem pode dizer que comer com as mãos não é a solução. Daniel faz isso; não deixa de se alimentar, como lhe é possível.

Se a descrição do sintoma pode ser pensada não apenas como disfunção, mas como um modo de ser, aproximamo-nos do terreno da AID.

É necessário, no entanto, abandonar o resto.... Não será possível, no plano desse trabalho, fazermos uma pesquisa neurológica ou neuropsicológica, pois não é este o recorte metodológico pelo qual optamos. Assim, não sabemos do cérebro de Daniel, e as questões anatômicas, fisiológicas e neuroquímicas são pedras preciosas nessa área. Mas, ao recortarmos das ideias de Luria os interesses nos termos sistema, organização, descrição, ação e função podemos ter aí um potencializador para a observação descritiva de crianças em relação, com o mundo e com as pessoas, em casos-limite como esse.

Se abandonamos, por método, a pesquisa anatômica e fisiológica, ainda podemos manter um estilo de pensar, observar e descrever os sintomas (leia-se, as ações e modos de ser) do modo como Luria o faz. Ou seja, detalhada e pormenorizadamente, em situações concretas da vida, por meio da descrição do modo como se leva a cabo as ações cotidianas. Rastreando, nessa descrição, os descompassos, desenlaces e diferenças que constituem a ação em relação à expectativa do observador. E os termos de que se utiliza são também bons aliados, na medida que permitem uma caracterização descritiva e não causal ou teórica (como o termo melodia cinética que se refere à fluidez e plasticidade da ação motora).

Como se vê, aqui já tangenciamos o território da AID, porque tratamos de jogo de expectativas e desenlaces e estranhamentos (entre expectativas). No entanto, mais um passo é necessário: é completamente diferente tratar de expectativas no diapasão do discurso e das relações como imaginadas, e das expectativas entre ações e 
comportamentos normais (típicos) e ações e comportamentos efeito de distúrbios neurológicos. Como solucionar?

Não temos respostas em definitivo, muito menos gerais. No entanto, na especificidade da situação concreta, podemos pensar algumas saídas.

A situação concreta a que nos referimos é justamente aquela dos modos de ser e de viver do menino Daniel. Em seu caso, o discurso é literalmente ato, como ação motora. Seu corpo é veículo direto de suas intenções, expectativas, vontades.... de seu "mundo interno", numa linguagem mais psi. É veículo de seu afetos, sentimentos e emoções. Talvez, inclusive, mais do que veículo: é justamente no corpo que seu mundo se constitui, na ação real de seus braços e pernas; alguém para quem fazer é pensar, pensar é fazer.

Se é assim, o discurso de Daniel é inalienável de sua faceta neurológica, que constantemente parece imprimir àquele as marcas de seu modo de funcionar. Para ele, e talvez para casos como seu, o neurológico se confunde e se mescla com a "personalidade", com o desenho possível de si e com os modos de se relacionar. É radical a marca que se constitui na relação entre duas pessoas quando uma dessas é incapaz de dominar e controlar por completo e por si mesma o próprio corpo e movimento, que são, afinal, tudo do que dispõe para se relacionar.

Se insistimos, ainda, em uma AID, é porque ela nos instrumenta a colocar esse corpo, assim constituído, no discurso. E pensá-lo na relação que, com seus recursos e modos particulares, é, sim, capaz de ensejar. Com tudo isso, a produção de sentidos e ações (ou, ações e sentidos, ou ainda, sentidos nas ações) viabiliza-se.

\section{Referências}

Luria, A. (1973/1981). Fundamentos de Neuropsicologia. São Paulo: Ed. Universidade de São Paulo 